Doktori (Ph.D.) értekezés

\author{
Terecskei Kata
}

Biológia Doktori Iskola

Szeged

2013 


\title{
Egy kis GTP-kötő fehérje szerepe a növényi cirkadián óra, stressz-válaszok és a fényfüggő endoreduplikáció szabályozásában
}

\author{
Doktori (Ph.D.) értekezés
}

Készítette: Terecskei Kata

Témavezető: Dr. Kozma-Bognár László

\author{
Magyar Tudományos Akadémia \\ Szegedi Biológiai Központ \\ Növénybiológiai Intézet \\ Foto- és Kronobiológiai Csoport
}

\author{
Szegedi Tudományegyetem \\ Természettudományi és Informatikai Kar \\ Biológia Doktori Iskola
}

Szeged 


\section{TARTALOMJEGYZÉK}

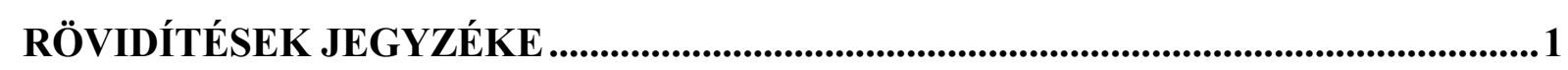

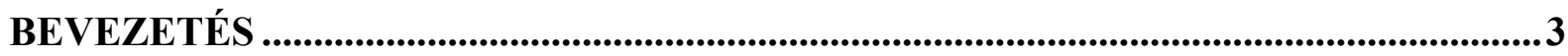

SZAKIRODALMI ÁTTEKINTÉS ...............................................................................4

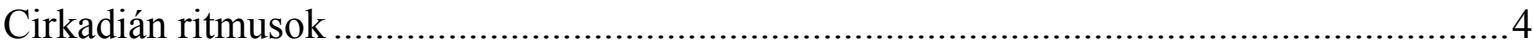

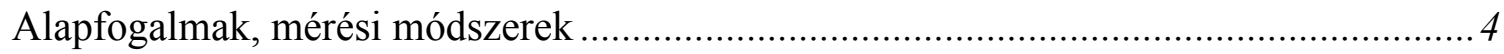

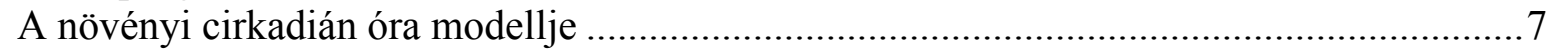

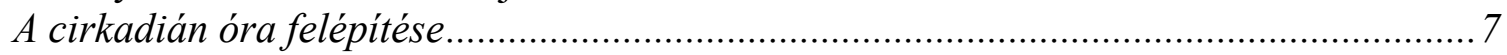

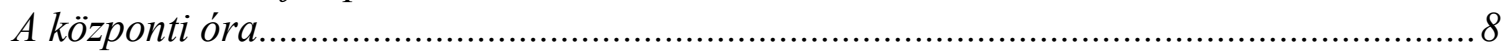

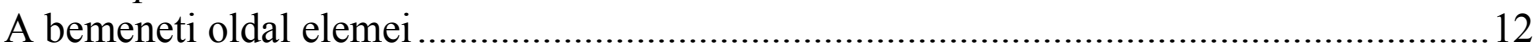

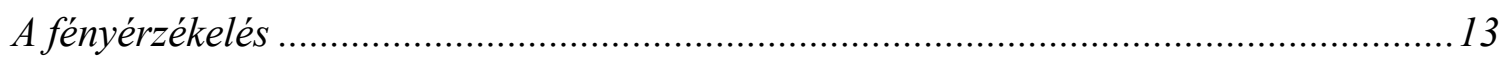

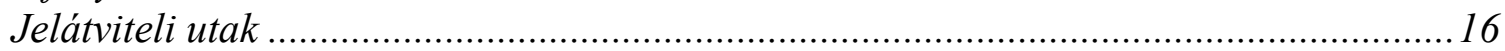

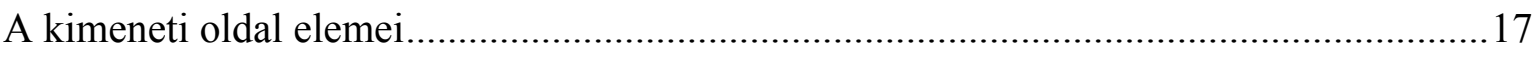

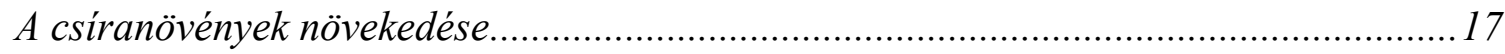

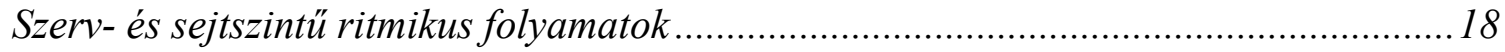

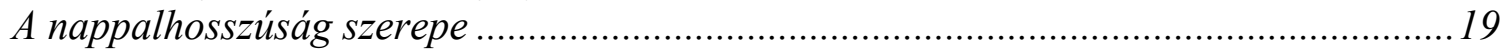

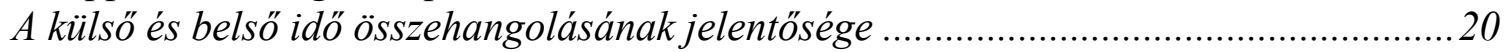

A hormonok szerepe a cirkadián óra kimenetének szabályozásában.............................20

A LIGHT INSENSITIVE PERIOD 1 (LIP1) szerepe a cirkadián óra szabályozásában ..... 21

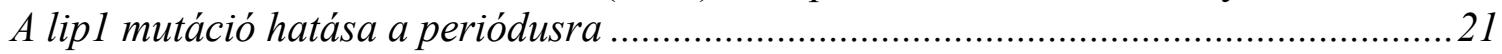

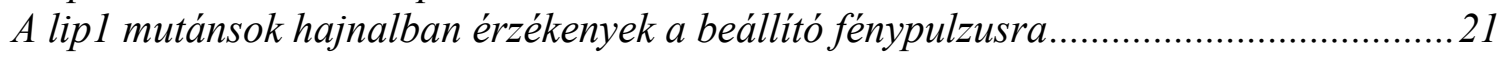

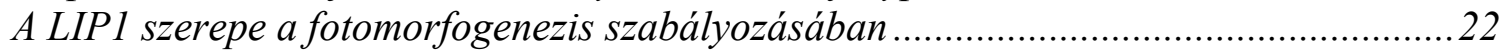

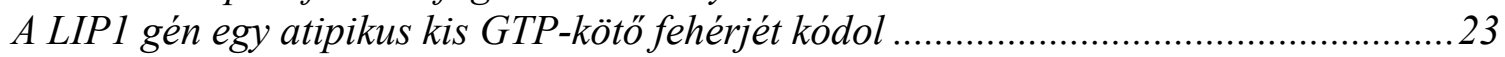

Az abiotikus stressz-válaszokban szerepet játszó jelátviteli utak.........................................24

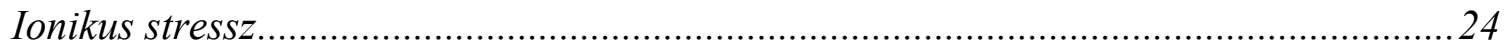

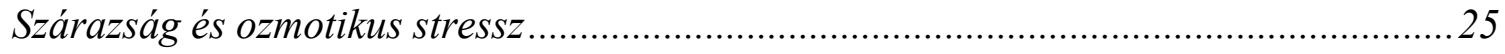

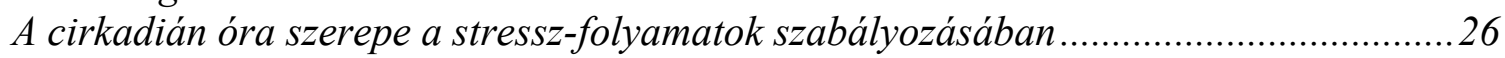

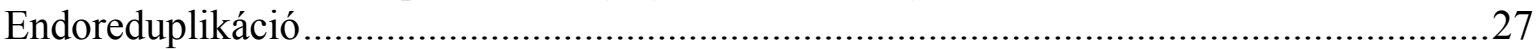

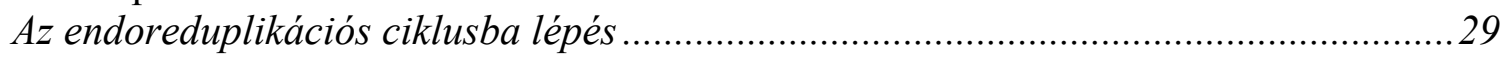

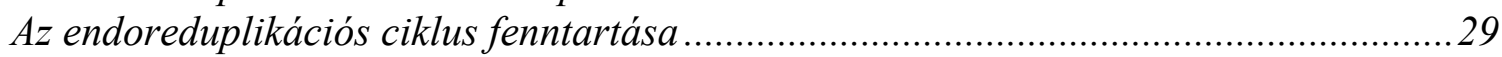

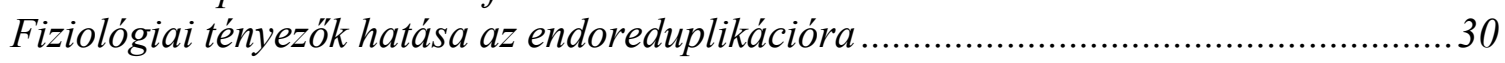

A fitokrómok szerepe az endoreduplikáció szabályozásában ........................................ 31

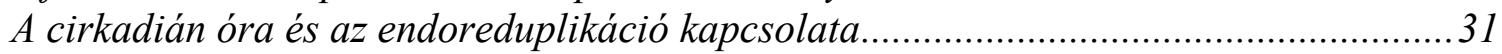

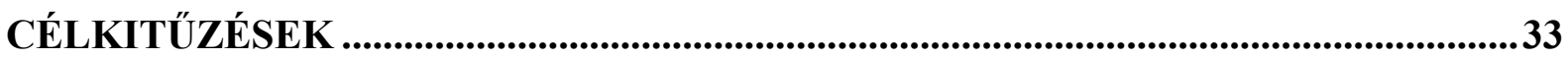

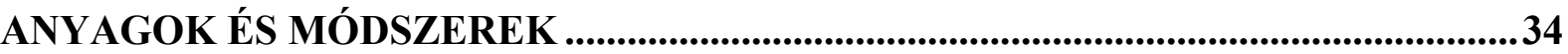

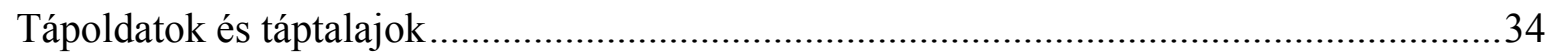

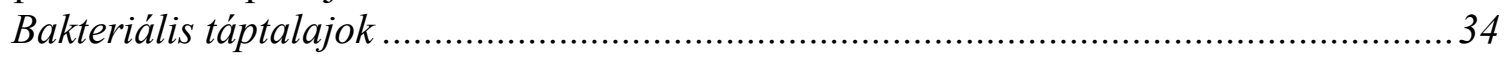

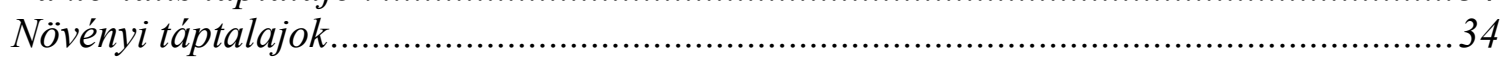

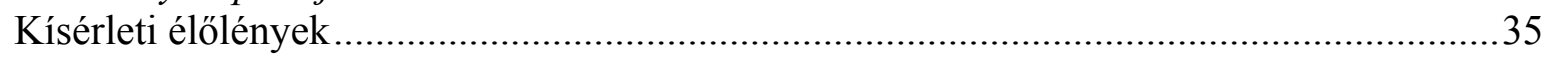

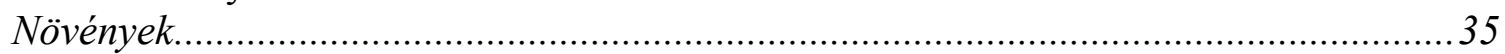

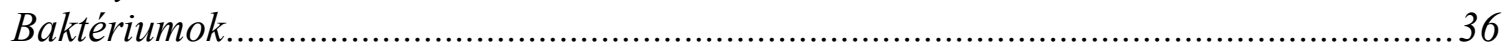

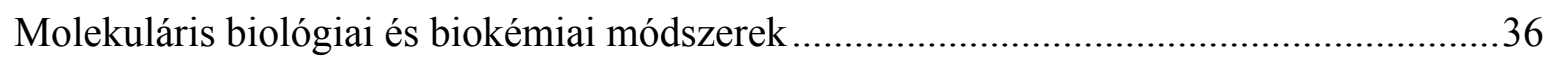

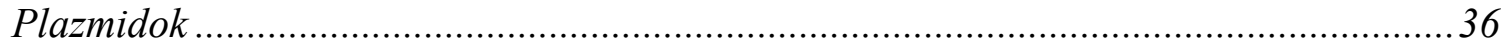

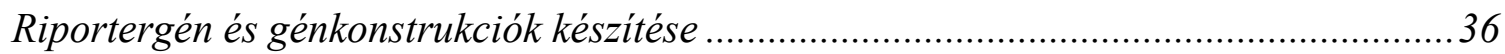

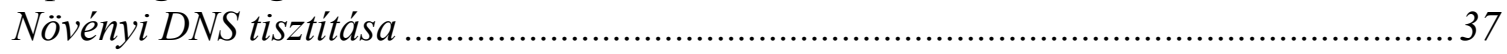

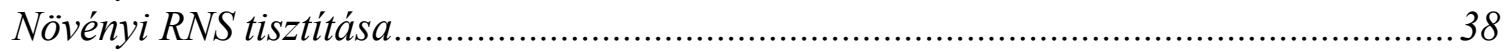




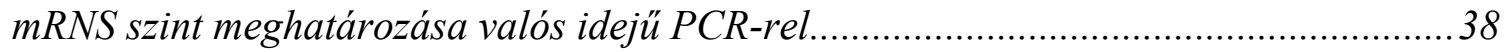

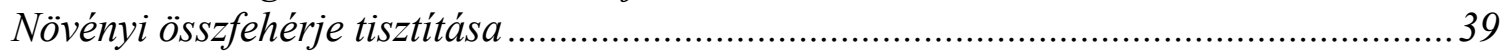

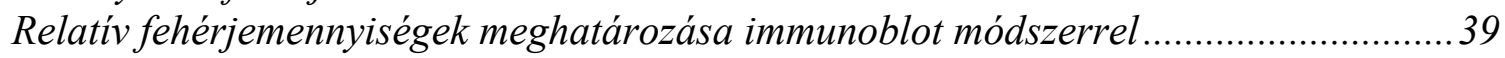

Növények előkészítése és nevelése, alkalmazott vizsgálatok .......................................40

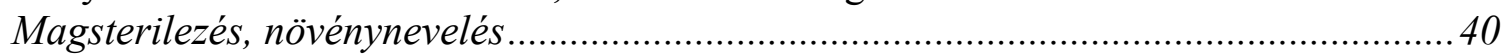

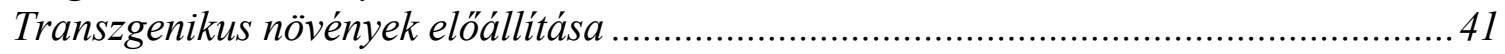

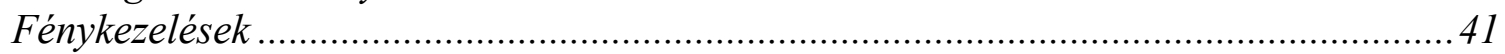

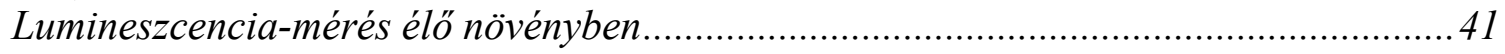

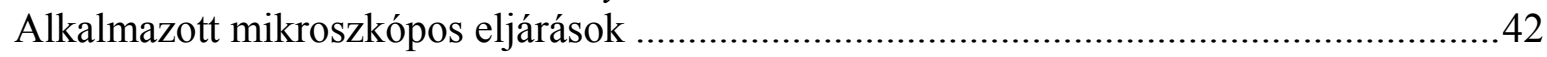

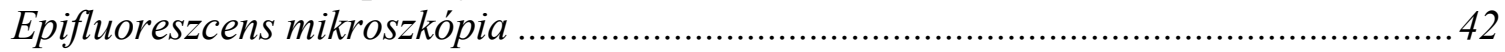

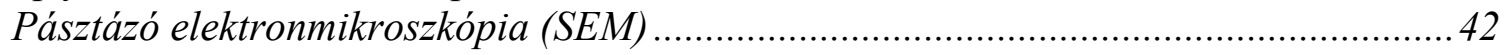

Differenciál interferencia kontraszt (DIC) mikroszkópia és a sejtalak faktor számítása.43

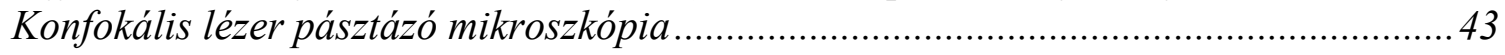

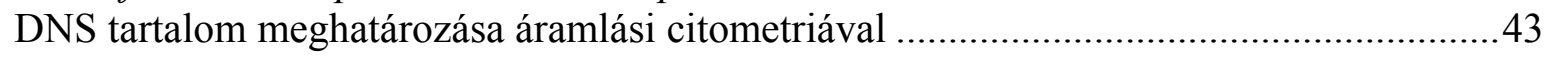

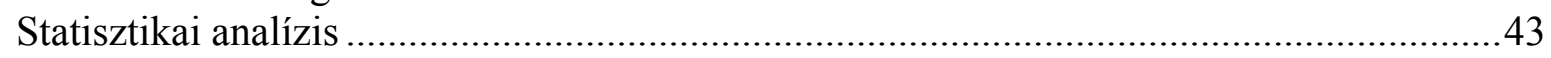

EREDMÉNYEK ...............................................................................................................44

A LIP1 fehérje hiányában megváltozik a sziklevél felszíni bőrszöveti sejtjeinek alakja.....44

A lip1 mutáns növényekben megnő a magi DNS mennyisége .........................................46

A LIP1 fehérje hatása a csíranövények kromatintartalmára ............................................46

A LIP1 fényfüggő módon gátolja az endoreduplikációt .............................................. 47

A LIP1 szerepe a fotomorfogenezis szabályozásában a fitokróm B-től és a kriptokróm 1-2-

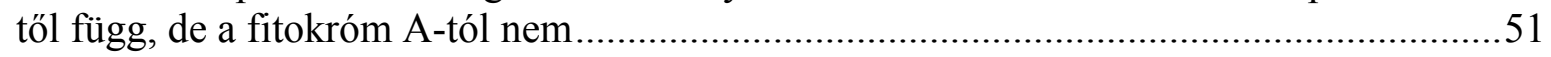

A lip 1 mutánsok fokozottan érzékenyek az abiotikus stresszre .....................................52

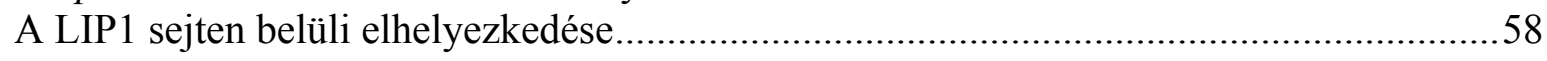

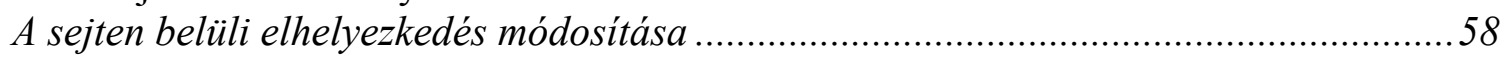

A LIP1 fehérje sejtmagi elhelyezkedése esszenciális a cirkadián funkció ellátásához ....59

A LIP1 szerepe a cirkadián óra szabályozásában...............................................................64

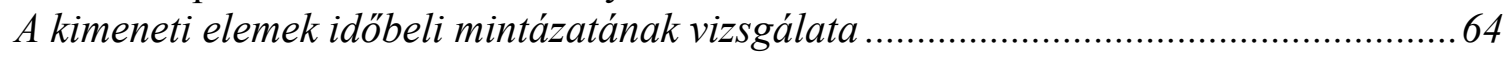

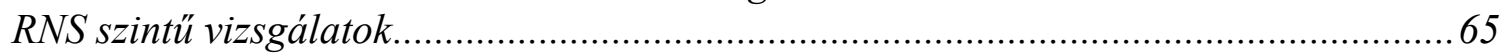

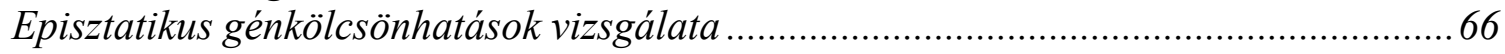

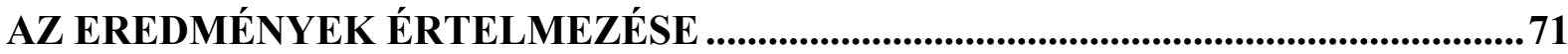

A LIP1 pleiotróp funkcióinak vizsgálata....................................................................... 71

A LIP1 az endoreduplikáció szabályozásában fényfüggő módon vesz részt ..................... 71

A LIP1 fitokróm B és kriptokróm 1-2 függö módon szabályozza a fotomorfogenezist .... 71

LIP1 fehérje hiányában a növények érzékenysége megnö az ozmotikus stresszel szemben

Kis GTP-kötö fehérjék szerepe a stressz-válaszokban, a ploidia szint meghatározásában

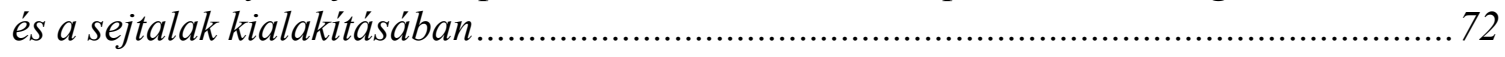

A lip1 mutáció okozta fenotípusok komplementálhatósága ............................................ 74

A LIP1 szerepe a növények fejlödésének korai szakaszában fontos ............................... 74

A LIP1 és a cirkadián óra kapcsolata ..................................................................... 75

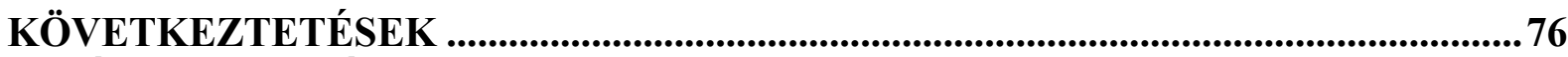

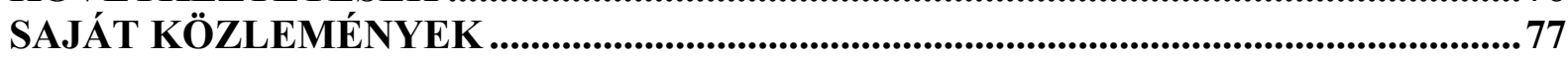

IDÉZETT KÖZLEMÉNYEK ……..........................................................................78

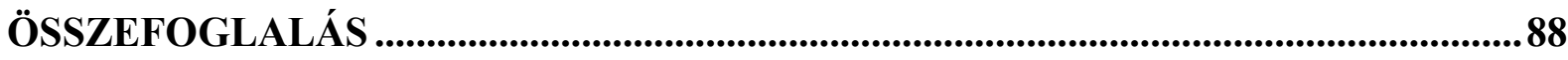

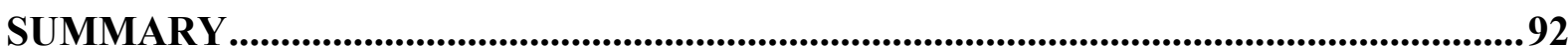

KÖSZÖNETNYILVÁNÍTÁS..................................................................................97 


\section{RÖVIDÍTÉSEK JEGYZÉKE}

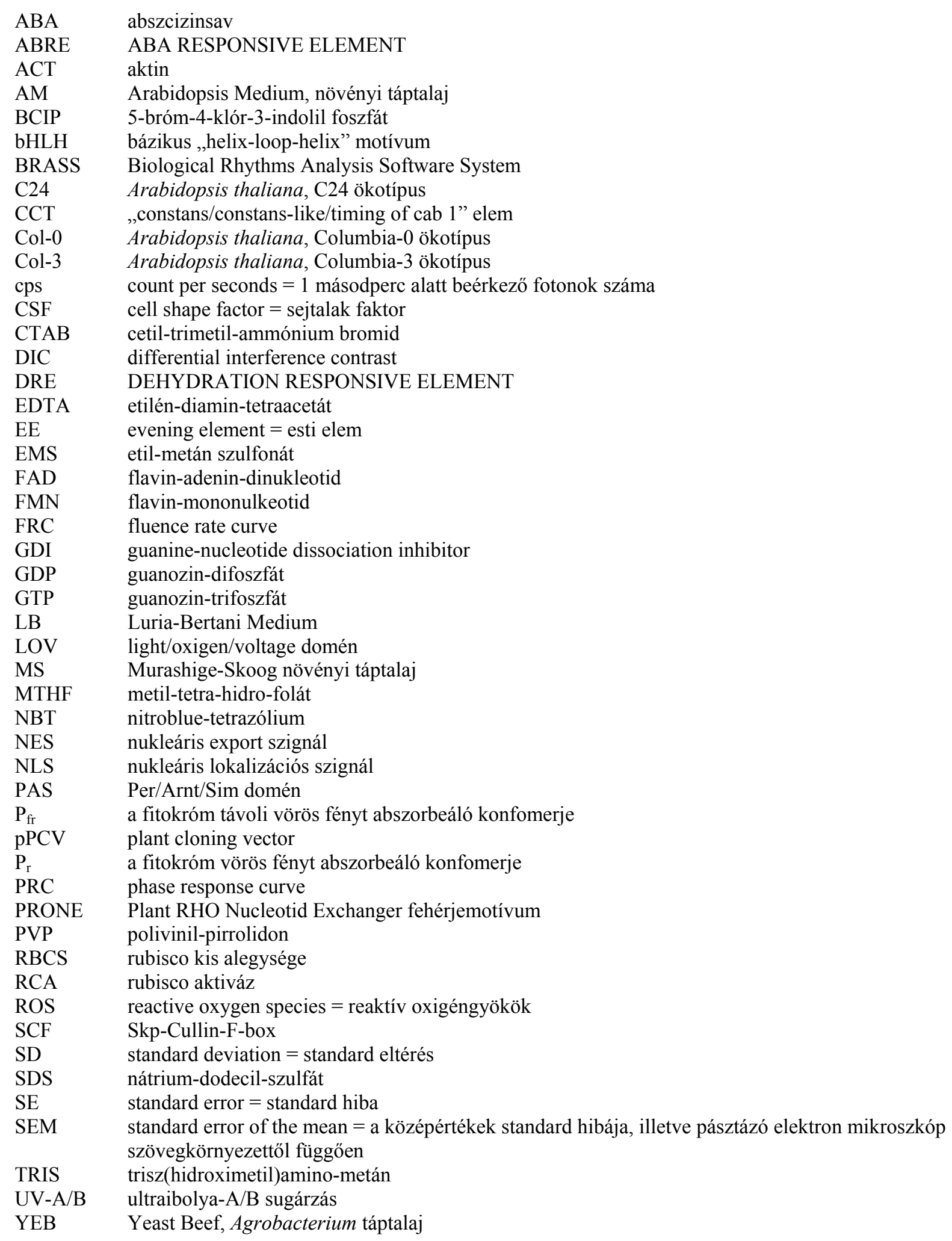




\section{GÉNSZIMBÓLUMOK}

\begin{tabular}{|c|c|}
\hline $\mathrm{ABF}$ & ABRE-BINDING FACTOR \\
\hline ABAR & ABA-BINDING PROTEIN \\
\hline ACS & AMINO-CYCLOPROPANE-CARBOXYLATE SYNTHASE \\
\hline CAB & CHLOROPHYLL A/B-BINDING \\
\hline $\mathrm{CBF}$ & C-REPEAT BINDING FACTOR \\
\hline $\mathrm{CCA}$ & CIRCADIAN CLOCK ASSOCIATED \\
\hline CCR & COLD CIRCADIAN CLOCK REGULATED \\
\hline $\mathrm{CHE}$ & CCA1 HIKING EXPEDITION \\
\hline CDK & CYCLIN DEPENDENT KINASE \\
\hline CIR & CIRCADIAN \\
\hline CK & CASEIN KINASE \\
\hline CKB & CASEIN KINASE $\beta-$ SUBUNIT \\
\hline CKI & CYCLIN DEPENDENT KINASE INHIBITOR \\
\hline $\mathrm{COP}$ & CONSTITUTIVE PHOTOMORPHOGENESIS \\
\hline COR & COLD RESPONSIVE \\
\hline CRY & CRYPTOCHROME $=$ kriptokróm \\
\hline CYC & CYCLIN $=$ ciklin \\
\hline DET & DE-ETIOLATED \\
\hline DREB & DEHYDRATION RESPONSIVE ELEMENT BINDING \\
\hline ELF & EARLY FLOWERING \\
\hline EPR & EARLY PHYTOCHROME-RESPONSIVE \\
\hline FHY & FAR RED ELONGATED HYPOCOTYL \\
\hline FIO & FIONA \\
\hline FKF & FLAVIN BINDING KELCH F-BOX \\
\hline FT & FLOWERING LOCUS T \\
\hline GFP & GREEN FLUORESCENS PROTEIN \\
\hline GI & GIGANTEA \\
\hline GUN & GENOME UNCOUPLED \\
\hline HY & ELONGATED HYPOCOTYL \\
\hline $\mathrm{HYH}$ & HY5 HOMOLOG \\
\hline KRP & KIP- RELATED PROTEIN \\
\hline LHY & LATE ELONGATED HYPOCOTYL \\
\hline LIP & LIGHT INSENSITIVE PERIOD \\
\hline LUC & LUCIFERASE Photinus pyralis \\
\hline LUX & LUX ARRHYTHMO \\
\hline MYB & MYELOBLASTOSIS VIRAL ONCOGENE HOMOLOG \\
\hline PER & PERIOD \\
\hline PHOT & PHOTOTROPIN = fototropin \\
\hline PHY & PHYTOCHROME = fitokróm \\
\hline PIF & PHYTOCHROME INTERACTING FACTOR \\
\hline PIL & PHYTOCHROME INTERACTING FACTOR-LIKE \\
\hline PRR & PSEUDO RESPONSE REGULATOR \\
\hline RAB & RESPONSIVE TO ABA \\
\hline $\mathrm{RCC}$ & REGULATOR OF CHROMATIN CONDENSATION \\
\hline $\mathrm{RD}$ & RESPONSIVE TO DESICCATION \\
\hline ROP & RHO OF PLANTS \\
\hline RVE & REVILLE \\
\hline SIM & SIAMASE \\
\hline SOS & SALT OVERLY SENSITIVE \\
\hline SPY & SPINDLY \\
\hline SRR & SENSITIVITY TO RED LIGHT REDUCED \\
\hline TEJ & „fényes” szanszkrit megfelelöje \\
\hline TIC & TIME FOR COFFEE \\
\hline TOC & TIMING OF CAB \\
\hline UVR & UV RESISTANCE LOCUS \\
\hline YFP & YELLOW FLUORESCENS PROTEIN \\
\hline ZTL & ZEITLUPE \\
\hline
\end{tabular}




\section{BEVEZETÉS}

24 órás gyakorisággal ismétlődő folyamatok szinte minden élőlényben megfigyelhetőek. Ezek a periodikusan változó folyamatok állandó környezeti körülmények között is fennmaradnak napokig vagy akár hetekig, mivel egy belső ritmusgeneráló rendszer, a cirkadián óra fenntartja őket. A ritmus a környezetünkben tapasztalható nappal/éjjel ciklushoz környezeti jelek segítségével igazodik.

Az óra összhangja a külső környezeti idővel adaptív előnyt jelent az élőlények számára, segítségével a metabolikus és fiziológiai folyamataikat megfelelően tudják időzíteni a nap folyamán. A kétszikü Arabidopsis thaliana a laboratóriumi vizsgálatok során gyakran használt modell növény. Ebben a növényben a megfelelően beállított cirkadián óra hozzájárul a klorofill tartalom növekedéséhez, a fotoszintetikus szén fixálás hatékonyabbá tételéhez, ezáltal a gyorsabb növekedéshez és nagyobb biomassza termeléséhez is. A cirkadián óra kölcsönhat a stressz és a hormon jelátviteli utakkal is. A vegetatív növekedés során az óra nemcsak a külső fényjelekre, hanem a hőmérsékletváltozásra és a stresszre adott válaszokat is szabályozza.

A cirkadián óra szerepét a növények növekedésének és fejlődésének szabályozásában mi sem bizonyítja jobban, mint az, hogy milyen fontos szerepe van a napszakos változásoknak olyan hosszú távú folyamatokban, mint az egyes szervek fejlődése, vagy a szezonális változások. Az óra szerepe egy folyamaton belül is többszintü lehet. Kiváló példája ennek a virágzás fotoperiodikus szabályozása. Az óra szerepe a stressz-válaszok és az anyagcsere szabályozásában, a csírázási képesség befolyásolásában, a növekedés és virágzás szabályozásában sokkal fontosabb lehet, mint korábban gondoltuk. Az óra által szabályozott folyamatok modellje egyre bonyolultabbá és komplexebbé válik, amint összegezni próbáljuk a külső környezeti jelekre adott párhuzamos válaszokat és az egyes óra komponensek különböző válaszokban betöltött többrétű szerepét.

Munkánk során a LIGHT INSENSITIVE PERIOD 1 (LIP1) vizsgálatával foglalkoztunk, ami több különféle életfolyamatban is részt vesz. A LIP1 szerepet játszik a cirkadián óra és a fotomorfogenikus folyamatok szabályozásában, az endoreduplikáció befolyásolásában és bizonyos stressz folyamatokban is. 


\section{SZAKIRODALMI ÁTTEKINTÉS}

\section{Cirkadián ritmusok}

\section{Alapfogalmak, mérési módszerek}

A Föld tengely körüli forgásának következtében napszakos változások figyelhetőek meg bizonyos környezeti tényezők esetében. Ilyen például a hőmérséklet és a fényviszonyok ciklikus változása a nap folyamán. Az evolúció során az élőlények alkalmazkodni kezdtek ezekhez a napszakosan változó körülményekhez, megtanultak időben felkészülni a periodikusan bekövetkező változásra. Ez az alkalmazkodó képesség teszi lehetővé, hogy a környezeti jelek érzékelésével, illetve az azokban bekövetkező változások előre jelzésével az élőlények a legmegfelelőbb időpontra tudják időzíteni belső folyamataikat. A külső idő érzékelése és az ezzel való szinkronizációs képesség egyaránt az ún. „belső órának” köszönhető, amely méri a külső időt és ugyanakkor egy belső, hozzávetőlegesen 24 órás ritmust is generál (Bell-Pedersen és mtsai, 2005). A cirkadián ritmusok napi rendszerességgel ismétlődnek (latin circa diem, egy nap körüli). Cirkadián szabályozás alatt áll az emberi alvás/ébrenlét ciklus, de a testhőmérséklet és a vérnyomás is. Cirkadián ritmusok szinte minden, az éjszakák és nappalok váltakozásának kitett élőlényben megfigyelhetők az egysejtűektől a gombákon át, egészen a növényekig és a gerincesekig (Dunlap, 1999).

A cirkadián ritmus jellemző változói Roenneberg és Merrow (2001) szerint:

- a külső környezeti jelek hiányában is fennmaradó ritmus (jelen esetben a szinusz görbének megfelelő oszcilláció);

- a 24 órás periódus (egy teljes ritmikus ciklus időtartama, egy jelenség ismétlődési gyakorisága);

- a kellően erőteljes amplitudó (a szinusz görbe minimuma és maximuma közti különbség), ami a kimeneti jelek fenntartásához szükséges;

- a ritmus önfenntartó képessége;

- a hőmérséklet kompenzáció (bizonyos hőmérséklet-tartományon belül az óra képes kompenzálni a hőmérsékletingadozást, így a szabadon futó ritmus periódusa és erőteljessége nem változik);

- a beállíthatóság (a ritmus külső 24 órás ciklushoz való egyeztethetőségének képessége). 


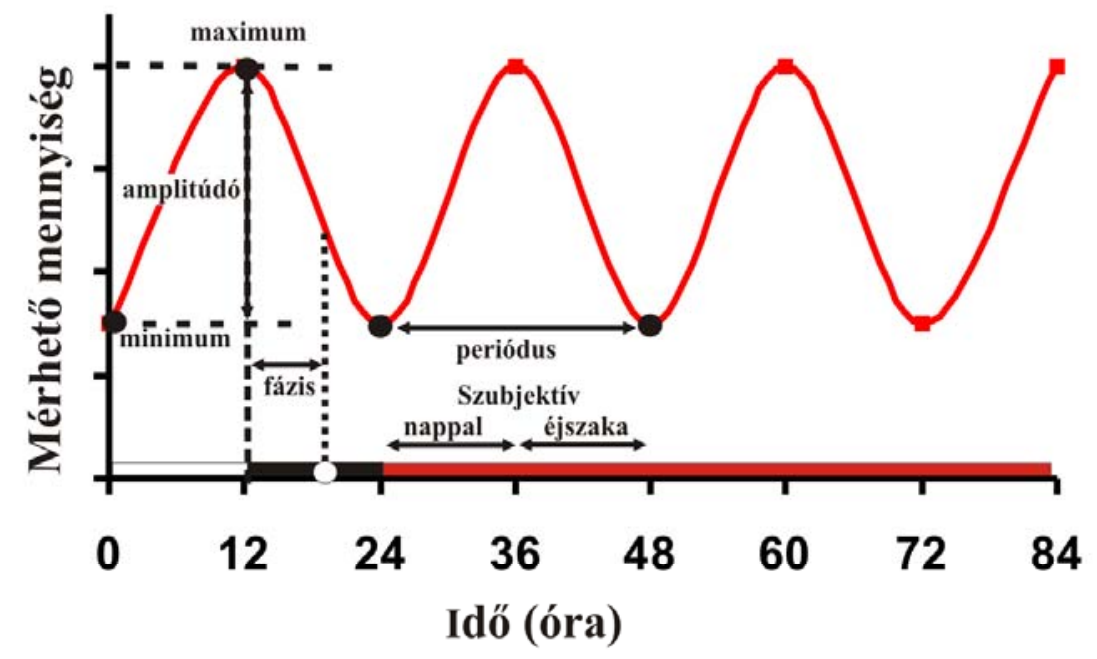

1.ábra. Cirkadián ritmusok jellemző paraméterei

Az ábrán cirkadián óra által szabályozott folyamatok mérhetö tulajdonságai láthatóak. A beállító fényviszonyokat a fekete és fehér szakaszok jelölik az x tengelyen. Változatlan fényviszonyok között a szubjektív éjszaka és nappal fogalmával azt fejezzük ki, hogy mikor következne a beállító fény/sötét váltásoknak megfelelö napszak. Kísérleteink során az utolsó beállító nappal kezdetétől számítjuk az eltelt időt. Periódusnak nevezzük két egymást követő minimum vagy maximum pont idöbeli távolságát. A minimum és maximum érték közötti kitérés az amplitudó. A ritmus fázisa azt mutatja meg, hogy a cirkadián cikluson belül hol tartózkodik a rendszer egy adott vonatkoztatási ponthoz képest. Ezt rendszerint a görbe csúcsidejének és a viszonyítási időpontnak a különbségeként adjuk meg.

A cirkadián ritmus legfontosabb paramétereit az 1. ábra mutatja be. Ha egy cirkadián tulajdonság kifejeződését az idő függvényében ábrázoljuk, akkor a periódust a görbe két azonos pontjának (pl. az egymást követő csúcsoknak) időbeli távolsága adja meg. Ha csökken a távolság, akkor a periódus rövidebb lesz, ha nő, akkor hosszabb. A szabadon futó cirkadián ritmusok periódusa általában 24 óra. A ritmus fázisa azt mutatja meg, hogy a cirkadián cikluson belül hol tartózkodik a rendszer egy választott vonatkoztatási ponthoz képest. A ritmust erőteljesnek mondjuk, ha a kitérések nem változnak számottevően az egymást követő ciklusok során. Szubjektív éjszakaként vagy nappalként tüntetjük fel a állandó körülmények között a beállító fény/sötét ciklusoknak megfelelő időszakokat. Ezzel azt fejezzük ki, hogy ekkor következne a megfelelő napszak. Kísérleteink során az utolsó beállító nappal kezdetétől számítjuk az eltelt időt. A cirkadián óra müködése a legkönnyebben úgy követhető nyomon, ha egy általa vezérelt gén promóterét a szentjánosbogár luciferáz (LUC) génjéhez fúzionáljuk (Somers és mtsai, 1998a). A luciferáz reakciót fénykibocsátás kíséri, a módszerrel a génkifejeződés cirkadián ritmusa hosszú ideig mérhető élő növényben is.

A cirkadián órát be lehet állítani rövid fénypulzussal is. Attól függően, hogy az óra milyen fázisban tart éppen, ez késést vagy sietést okoz. Az óra a nap egy részében szinte teljesen 
érzéketlen a beállító fényjelekre, a legnagyobb fáziscsúszásokat pedig a szubjektív éjszaka közepén lehet kiváltani. Ha a szabadon futó rendszert különböző időpontokban adott azonos erősségü és időtartamú fénypulzusokkal állítjuk be, és a mért fáziscsúszásokat az adott fénypulzusok idejének függvényében ábrázoljuk, megkapjuk az adott minőségü és intenzitású fénypulzusra adott fázisválasz görbéjét (PRC, Phase Response Curve) (Johnson, 1992) (2. ábra A).

Szabadon futó körülmények között a periódus a legtöbb élőlényben függ az alkalmazott fény erősségétől (Aschoff, 1979). Növényeknél minél erősebb a fény, annál rövidebb a periódus. A periódus fényerősségtől való függését a fényerősség-függés görbe (FRC, Fluence Rate Curve) segítségével vizsgálhatjuk. Az azonos módon beállított növényeket eltérő erősségü állandó monokromatikus fénybe helyezzük 96-120 órára, majd a periódushosszt mérjük és az alkalmazott fényerősség tízes alapú logaritmusának függvényében ábrázoljuk (2. ábra B).

A

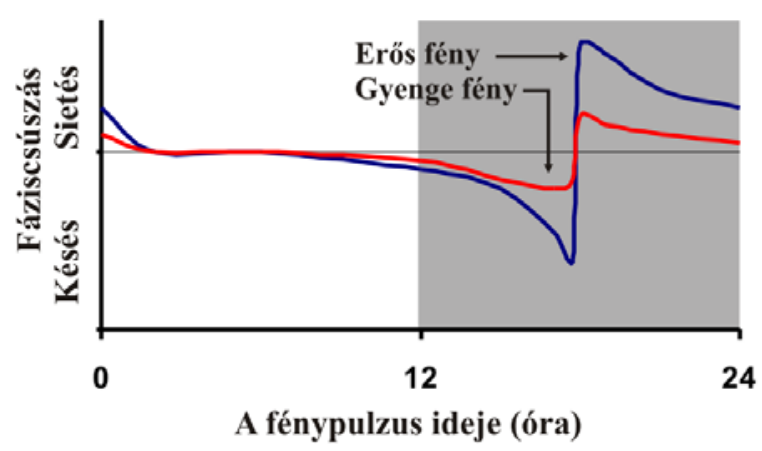

B

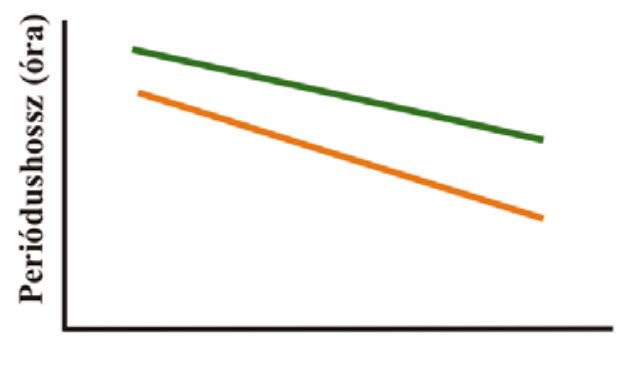

Fényerősség logaritmusa

\section{2. ábra. A fény hatása a cirkadián órára}

Az óra beállitásának alapja, hogy egy központi óraelem müködését egy fénypulzus ideiglenesen meg tudja változtatni. Attól függöen, hogy a pulzus milyen fázisban éri az órát, sietést vagy késést vált ki.

(A) A sietéseknek és késéseknek a fénypulzus idejének függvényében való ábrázolásával kapjuk a fázisválasz görbét (PRC, Phase Response Curve). Erős pulzusokkal nagyobb fáziscsúszásokat lehet kiváltani, mint gyengébbekkel.

(B) Az állandó körülmények között kialakuló periódust az alkalmazott fényerösség tízes alapú logaritmusának függvényében ábrázolva kapjuk a fényerősség-függés görbét (FRC, Fluence Rate Curve). Az ábrázolt egyenesek eltérö meredeksége az óra megváltozott fényérzékenységére utaló példa. 


\section{A növényi cirkadián óra modellje}

A cirkadián óra körülbelül a gének 10-16\%-ának transzkripcióját szabályozza Arabidopsisban (Covington és mtsai, 2008). A cirkadián óra által generált ritmus abban különbözik a külső környezeti jelekre adott válaszoktól, hogy állandó körülmények (állandó fény vagy sötétség) között is fennmarad. A cirkadián ritmusok környezeti jelekkel a nappaléjjel ciklusokhoz igazíthatóak. Ilyen környezeti jelek például a változó hőmérsékleti és fényviszonyok hajnalban és szürkületkor, bár a beállító környezeti jelek más időpontokban is hatásosak lehetnek.

A növényi cirkadián óra által szabályozott folyamat például a levelek és a sziklevelek napszakos mozgása, a kloroplasztiszok sejten belüli rendeződése, a szik alatti szár megnyúlásának napszak-függése, a gázcserenyílások nyitása-zárása és a virágzás fotoperiodikus szabályozása (Yakir és mtsai, 2007). Belső oszcilláció figyelhető meg gének kifejeződési mintázatában, fehérjék kifejeződésében, a nukleocitoplazmikus eloszlásban, de egyes fehérjék foszforiláltsági mintázatában is (McClung, 2006).

\section{A cirkadián óra felépítése}

Leegyszerüsítve a növényi cirkadián óra három fő alkotórészből épül fel (3. ábra): az első a bemeneti rész, ami a környezeti jeleket érzékeli és továbbítja az óra felé, a második a központi óra (oszcillátor), ami a ritmust generálja, a harmadik pedig a kimeneti rész, ami az oszcillátort a különféle biológiai folyamatokkal köti össze. A központi óra és a kimeneti rész egyaránt visszahatnak a bemeneti részre, illetve a kimeneti részt is közvetlenül szabályozhatják a beérkező környezeti jelek (Más, 2008). A központi óra elemeit kódoló gének cirkadián ritmusban fejeződnek ki, és a jelenleg elfogadott modell szerint három pozitív/negatív visszacsatoláson alapuló kört alkotnak. 


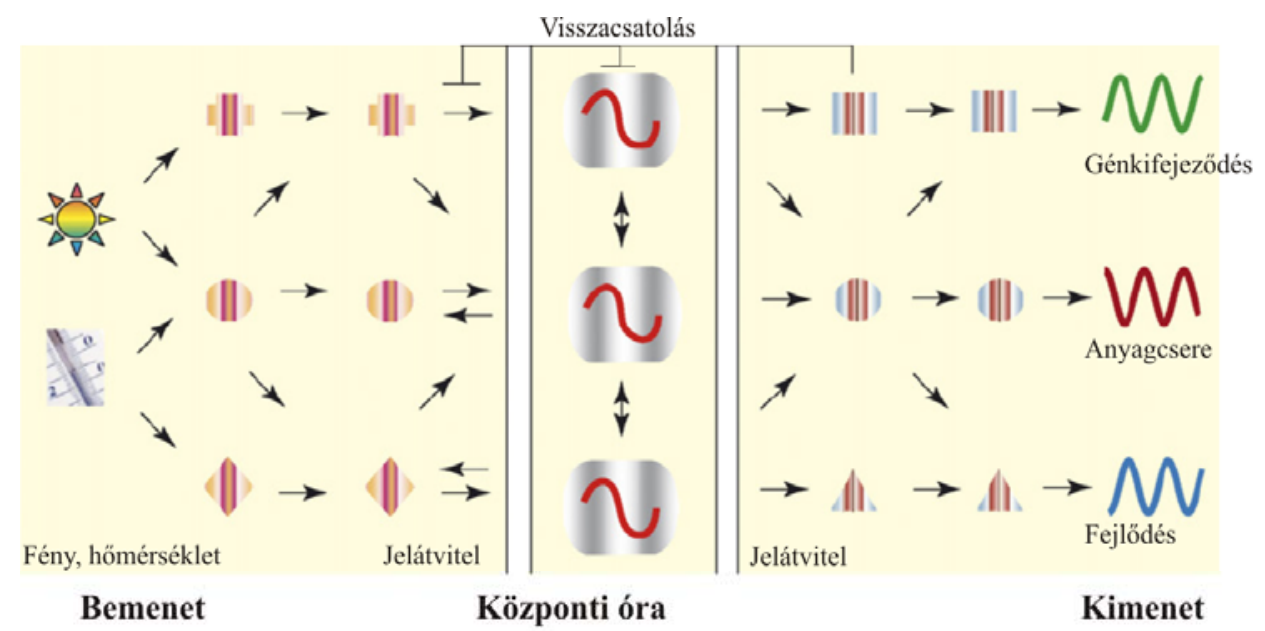

3. ábra. A cirkadián óra vázlatos felépítése

A cirkadián órát három egységre bonthatjuk. A központi óra (oszcillátor), amely a környezettöl függetlenül képes ismétlődő mintázat létrehozására. Azonban fontos, hogy a belső ritmus a külső, természetes ritmussal összhangban legyen. Az órabeállitást naponta a környezeti jeleket érzékelő molekulák és a hozzájuk kapcsolódó jelátviteli elemek központi órához való csatolása teszi lehetővé (bemenet). Az órát sokféle környezeti jellel be lehet állitani, de a két legfontosabb a fény és a hỏmérséklet. A létrehozott ismétlődő mintázat a kimeneti jelátviteli utakon keresztül nyilvánul meg különféle élettani folyamatokban, amelyek gén, illetve szerv szinten is megfigyelhetök. Az ábra eredeti verziója Más (2008) összefoglaló cikkéből származik.

\section{A központi óra}

A jelenleg elfogadott modell szerint Arabidopsisban a központi óra három visszacsatoláson alapuló körböl épül fel (McWatters és Devlin, 2011) (4. ábra). Az első körben a CIRCADIAN CLOCK ASSOCIATED 1 (CCA1) és a LATE ELONGATED HYPOCOTYL (LHY) MYB-típusú transzkripciós faktorok gátolják a TIMING OF CAB 1 (TOC1), vagy más néven PSEUDO RESPONSE REGULATOR 1 (PRR1) gén kifejeződését (Alabadí és mtsai, 2001). A PSEUDO RESPONSE REGULATOR géncsalád tagjai cirkadián ritmus szerint fejeződnek ki (Nakamichi és mtsai, 2005), 2-3 órás késéssel érik el a maximumot egymás után a nap folyamán, mégpedig úgy, hogy a $P R R 9$ az első a nap reggelén és a TOC1 az utolsó az este folyamán elért maximális kifejeződéssel. A CCA1 és LHY mRNS kifejeződésének maximuma a nap kezdetén figyelhető meg, míg a TOC1 kifejeződésének maximuma az esti órákra tehető. A nap folyamán a CCA1 és az LHY foszforilálódnak, majd az így módosult fehérjék lebomlanak. Ez a TOC1 kifejeződés gátlásának feloldásához vezet a délután folyamán, az így emelkedő TOC1 fehérje szint pedig a CCA1 és LHY gének kifejeződésének serkentésében fog szerepet játszani (McWatters és Devlin, 2011). A CCA1 és LHY olyan MYB-elem tartalmú DNS-kötő fehérjék, amelyek a DNS-en az ún. esti elemet (Evening Element, EE) (Harmer és mtsai, 2000; Alabadí és mtsai 2001) ismerik fel. Szerepük részben átfed: a két gén bármelyikének túltermelése minden vizsgált ritmus megszűnését (Wang és Tobin, 1998), hiánya a ritmusok periódusrövidülését okozza (Green és Tobin, 1999; 
Mizoguchi és mtsai, 2002), együttes hiányuk csaknem teljes aritmiával jár (Ding és mtsai, 2007a). Közvetlenül kötődnek a TOC1 promóteréhez, és gátolják annak müködését (Alabadí és mtsai, 2001). A TOC1 komplexet képez egy TCP transzkripciós faktorral, a CCA1 HIKING EXPEDITION (CHE)-vel, ami a CCA1 promoterhez kapcsolódik (Pruneda-Paz és mtsai, 2009). A CHE és TOC1 fehérjék közvetlen kölcsönhatásban állnak egymással és ugyanazon szakaszhoz kötődnek a CCA1 promoteren. A CHE feltehetően azon mechanizmus egyik fontos alkotóeleme, ami által a TOC1 a CCA1 kifejeződését szabályozza. Lehetséges, hogy a TOC1 és a CHE antagonisztikus hatásúak a CCA1 promoteréhez való kötésben. A CHE azonban az LHY promoteréhez nem képes kötni, így ezen gén szabályozásában feltehetően más TOC1-kötő partnereknek lehet szerepe. A központi szabályozás egy másik szintje lehet továbbá az, hogy a CCA1 és LHY képesek saját maguk és egymás kifejeződését is gátolni (Schaffer és mtsai, 1998; Wang és Tobin,1998).

Matematikai modellek alapján feltételezik egy ún. X elem létét, amely serkentő hatással van a CCA1/LHY gének kifejeződésére. Az X elem szerepét részben a TOC1 és a CHE, továbbá az EARLY FLOWERING 3 (ELF3) és/vagy az ELF4 molekulák töltik be (Locke és mtsai, 2005). ELF3 és ELF4 hiányában a CCA1/LHY kifejeződése drámaian lecsökken (Doyle és mtsai, 2002; Kikis és mtsai, 2005).

Az ún. reggeli szabályozó hurkot két PSEUDO RESPONSE REGULATOR, a PRR7 és PRR9, valamint az általuk negatívan szabályozott $C C A 1$ és $L H Y$ alkotják. A CCA1 és LHY fehérjék pedig kölcsönösen serkentik a PRR7 és PRR9 gének kifejeződését. A PRR-ek a karboxi-végükön egy CCT (CONSTANS, CONSTANS-LIKE, TOC1)-elemet hordoznak, amelyen egy sejtmagi lokalizációs szignál is található (Makino és mtsai, 2000). Az ilyen molekulák nem közvetlenül szabályozzák az átírást, hanem feltehetően segédfehérjéken keresztül (Ben-Naim és mtsai, 2006). A TOC1-hez hasonló gének mindegyikéről kimutatták, hogy közük van a cirkadián órához, noha az egyszeres mutánsok cirkadián fenotípusa nem jelentős. A tocl mutáns rövid periódusú fenotípust mutat (Sommers és mtsai, 1998), a prr5 mutáns szintén (Eriksson és mtsai, 2003), viszont a prr7 mutánsnak gyakorlatilag nincsen cirkadián fenotípusa (Nakamichi és mtsai, 2005), a prr9 mutáns pedig hosszú periódusú fenotípust mutat (Eriksson és mtsai, 2003). A többszörös mutánsok súlyosabban sérültek, például a prr7 prr9 dupla mutáns extrém hosszú periódusú, holott az egyszeres prr7 mutánsnak nincs is cirkadián fenotípusa. A legszélsőségesebb hatású a prr5 prr7 prr9 háromszoros mutáns, amelyben megszünik mindenféle ritmus (Nakamichi és mtsai, 2005). 


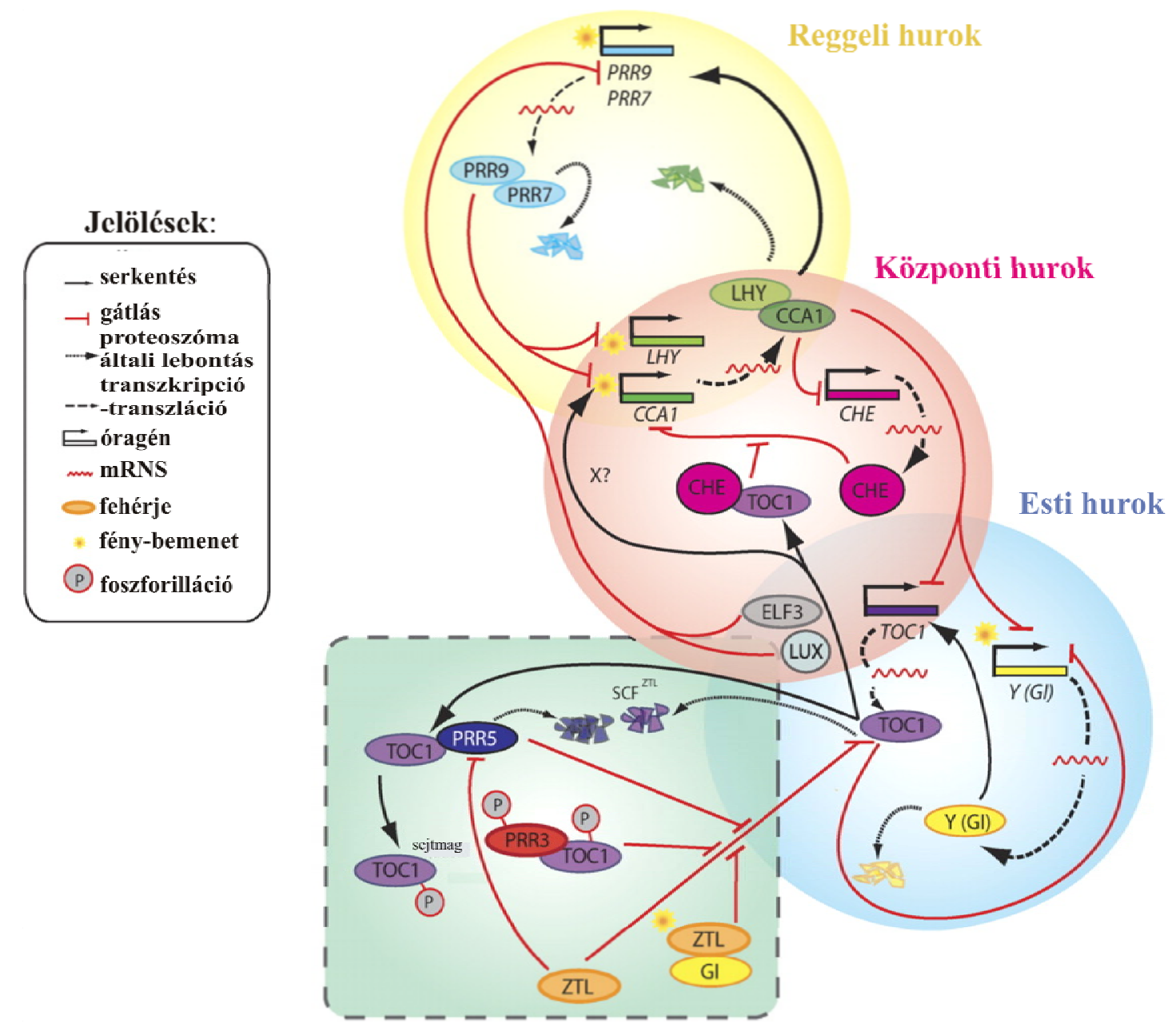

4. Śbra. A rōvényi eirksadíán óra modellje

A jelenlegi modell szerint a kōzponti oszeillátor három, negativ visezacsatoláson alapuló szahályozóhumkból êpül fel. A reggeli hurkot a CIRCADIAN CLOCK REGULATED 1 (CCA1) és a LATE ELONGATED HYPOCOTYL (LHY), két MYB-típusá fehérje és génjei, valamint a PSEUDO RESPONSE REGULATOR 7 és 9 (PRR7,9) fehérjék és génjeik alkotjajk. A CCA1/LHY fehérjék kỏzvetleniil serkentilk a $P R R 7 / 9$ génelk átíndását, a PRR-ek pectig kōzvetett módon gátolják a CCA1/LHY géneket. A kôzzponti hurakban a TOC1 egy feltetelezett X elemen keresztül serkenti a CCAI/LHY

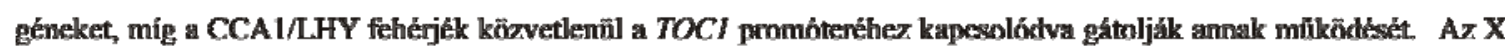
elem szerepét részben a CCA1 HIKING EXPEDITION (CHE) töhi be. A CHE kôzvetlenïil kôt a CCA1 promoterhez, gátolva a CCAI kifejezödését. A CHE kifejezỏdését a CCA1 gătolja. A CHE és a TOCI kõzti direkt fehérje-fehểje kölesōnhatrís pedig gátolja a CHE kötōdését a CCA1 promóterhez Az exti hurok tagjai a PRR-családba tartozb TTMING OF

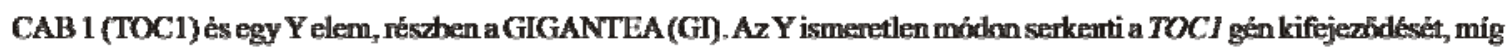
a TOC1 fehérje szintén ismenetien módon gátolja az $Y$ gént. A CCA1/LHY nemesak a TOCL, hanem az $Y$, valamint sajăt génjeik kifejezódúséne is gátló hatásssal vannak. Az EARLY FLOWERING 3 (ELF3) és LUX ARRHYTHMO (LUX) az esti hurok komponensei és a PRR7 kifejezödését gátoljäk. A TOC1 fehérje lebontásắt a ZTL-SCF-E3 ubikvitin ligáz komplex végzi, ezt a GI és ZTL közti fẻnyfüggó direkt tölesônhøatás gátolja. A PRR3 a ZTL-lel antagonizal a TOCI-hez

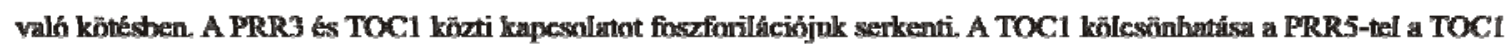
sejtmagi akkumulácibját segíti. Azảbra eredeti verziojja Haydane és mtsai (2011) cikkébỏl származik.

A harmadik szabályozó hurok az ún. esti időzítésü hurok. Ennek lényeges komponense egy ismeretlen Y elem, amelynek szerepe a TOC1 gén kifejeződésének serkentése. Az Y génről matematikai modellek alapján prediktálható, hogy mind a TOC1, mind pedig a CCA1/LHY gátolja (Locke és mtsai, 2005). Az Y funkcióinak egy részéért a GIGANTEA 
(GI) lehet a felelős, feltehetően további, eddig ismeretlen, illetve nem bizonyított faktorokkal együtt (Locke és mtsai, 2005; Zeilinger és mtsai, 2006). A GI (Mizoguchi és mtsai, 2005) egy nagyméretű sejtmagi fehérje, amely nem tartalmaz ismert fehérje motívumot. A GI mRNS és fehérje cirkadián módon fejeződik ki, kora esti maximummal (David és mtsai, 2006). A gi mutáns növényben az $L H Y$ és $C C A 1$ gének kifejeződése erősen csökkent, ami arra utal, hogy a GI a megfelelő $L H Y$ és $C C A 1$ szint kialakításában játszik szerepet. A gi mutánsok periódusa rövidebb a vad típusú növényekhez képest (Martin-Tryon és mtsai, 2007). A gi mutánsban a periódus fényerősség-függése is kisebb mértékü, mint a vad típusban (Park és mtsai, 1999).

Több olyan cirkadián szabályozó elem is ismert, amelyek nagy hatással vannak az órára, de nincsenek benne minden jelenleg elfogadott modellben. Ilyen például a LUX ARRHYTHMO (LUX), amelynek hiányában teljes aritmia tapasztalható (Hazen és mtsai, 2005b). A LUX egy MYB-szerű DNS-kötő elemmel rendelkező fehérje, amely szükséges a CCA1/LHY megfelelő szintjének kialakításához és a TOC1 ritmusának kialakulásához. A $L U X$ a TOC1-hez hasonlóan szabályozódik, mivel a CCA1/LHY a promóterében levő esti elemhez kötődve gátolja a kifejeződését. A REVILLE1 (RVE1), CIRCADIAN1 (CIR1/RVE2) és EARLY PHYTOCHROME RESPONSIVE1 (EPR1/RVE7) egy MYB traszkripciós géncsalád tagjai, mely családba a CCA1 és $L H Y$ is tartoznak (Kuno és mtsai, 2003; Yanhui és mtsai, 2006; Zhang és mtsai, 2007). Kifejeződési mintázatuk a CCA1 és $L H Y$-éhoz hasonló, azonban úgy tünik csak a CIR1-nek van szerepe a központi órában, az EPR1 és RVE1 az óra kimeneti útvonalaival állnak összeköttetésben. Az RVE1 összefüggésbe hozható az auxin szint cirkadián ritmusú modulációjával (Kuno és mtsai, 2003). A SPINDLY (SPY) fehérje, egy acetil-glükózamin transzferáz, kölcsönhat a GI-vel, és az óra sebességére van hatással (Tseng és mtsai, 2004). Szintén az óra sebességét befolyásolják a TEJ, egy poli-(ADP-ribóz)glikohidroláz (Panda és mtsai, 2002) és a FIONA 1 (FIO1), ami egy feltételezett metiltranszferáz (Kim és mtsai, 2008).

Az óragének átíródásának szabályozásán alapuló jelenlegi modell alapja az egyes komponensek mRNS szintjének időbeli változása. Az mRNS stabilitást és transzkripciót a cirkadián óra és a fény által szabályozott jelátviteli utak egyaránt befolyásolják (Kim és mtsai, 2003). Azonban fontos szerepet tölt be az óra müködésében az egyes komponensek fehérjéinek poszt-transzlációs szabályozása is, ami egyaránt hatással van a fehérjék müködésére és mennyiségére is. Sok órafehérje stabilitása a proteoszóma rendszer által szabályozott. A folyamat során a célfehérjét E3 ubiquitin ligázok ismerik fel és ubiquitinálják, majd a 26S proteoszóma bontja le őket. Az Skp/Cullin/F-box komplexek az E3 ubiquitin ligázok egy speciális csoportját képezik, ahol a szubsztrát-specificitás különböző F-box 
fehérjék által meghatározott (Lechner és mtsai, 2006). A TOC1 és homológja a PRR5 proteoszóma általi lebomlása egy fényfüggő F-box fehérje, a ZEITLUPE (ZTL) által szabályozott (Kiba és mtsai, 2007; Fujiwara és mtsai, 2008). A ZTL az éjszaka folyamán kötődik a TOC1-hez, 26S proteoszóma általi degradációját serkentve. Két ZTL homológ, a FLAVIN BINDING KELCH F-BOX 1 (FKF1) és a LOV KELCH PROTEIN 2 (LKP2) szintén kölcsönhatnak a TOC1-gyel (Más és mtsai, 2003). Ugyanakkor a ZTL és a GI között fényfüggő kapcsolat van, ami a GI fehérje szintet stabilizálja a nap folyamán (Kim és mtsai, 2007). Ez a kölcsönhatás gátolja a ZTL és a TOC1 közti interakciót. A TOC1 stabilizálását szolgálja továbbá, hogy komplexet képez a PRR3 fehérjével. Ez meggátolja a ZTL-lel való kölcsönhatást az éjszaka kezdetekor (Para és mtsai, 2007). Látható, hogy a TOC1 fehérje lebontása összetett folyamat, amelyben szerepet játszik a ZTL, a GI és a PRR3. Más órafehérjék szabályozott lebontása is megfigyelhető. A PRR3, PRR7 és PRR9 fehérjék szintje is az óra által szabályozott, de ez a ZTL-től független (Farré és Kay, 2007; Ito és mtsai, 2007; Fujiwara és mtsai, 2008).

A fehérje foszforilláció szintén egy olyan folyamat, ami az órakomponensek aktivitását és mennyiségét befolyásolja. A CASEIN KINASE 2 (CK2) $2 \alpha$ és $2 \beta$-alegységből épül fel. A CKB3 $\beta$-alegység a CCA1-et képes foszforilálni és ezáltal annak homodimer-képző, és DNSkötő képességét is szabályozni (Daniel és mtsai, 2004). A CKB4 alegység foszforillációját és degradációját is az óra szabályozza (Perales és mtsai, 2006). Cirkadián foszforillációs mintázat megfigyelhető továbbá a PRR család már említett tagjainál is (Farré és Kay, 2007; Fujiwara és mtsai, 2008). A TOC1 és a PRR3 foszforilált formái megnövekedett kölcsönhatási hajlamot mutatnak egymással. Ez arra utal, hogy a TOC1 stabilitásának szabályozásában foszforiláltsági állapotuknak fontos szerepe van és így kompetíció alakul ki, tekintve, hogy a ZTL-el vagy a PRR3-mal hat kölcsön a TOC1 (Fujiwara és mtsai, 2008).

\section{A bemeneti oldal elemei}

A cirkadián ritmusok periódusa nem pontosan 24 óra, ezért az elcsúszás elkerülése érdekében az órát naponta hozzá kell igazítani a külső időhöz. A beállítást környezeti tényezők (elsősorban a fény és a hőmérséklet) változása váltja ki. A változást erre specializálódott molekulák érzékelik és fordítják át biokémiai jelekre. Az érzékelő molekulák a jelet ezután a hozzájuk kapcsolt jelátviteli hálózaton keresztül juttatják el a központi órához. A jel az órafehérjék szintjét vagy müködését változtatja meg, mintegy finomhangolva ezzel a cirkadián órát. 


\section{A fényérzékelés}

A cirkadián órát a fény nem a fotoszintézis fényelnyelő és energiaátalakító rendszerén, hanem speciális érzékelő fehérjéken keresztül szabályozza. A fényérzékelő molekulákat, melyeken keresztül a fény a cirkadián órát eléri, az általuk elnyelt fény hullámhossza alapján három nagy csoportba oszthatjuk:

1. A vörös/távoli vörös fényt érzékelő fitokrómok (Nagy és Schaefer, 2002)

2. Az UV-A és kék tartományban elnyelő kriptokrómok (Lin, 2002)

és a ZTL család tagjai (Demarsy és Fankhauser, 2009)

3. UV-B fényérzékelő molekulák (Fehér és mtsai, 2011).

A fitokrómokat Arabidopsisban öt gén kódolja, a PHYA, -B, -C, -D és -E (Nagy és Schaefer, 2002). Az egyes gének által kódolt fehérjék nagyfokú homológiát mutatnak. A magasabbrendü növényekben található fitokrómok két $\sim 125 \mathrm{kDa}$ molekulasúlyú fehérje által alkotott dimerként vannak jelen natív formában. A PhyA esetében csak homodimer, a PhyB-E esetében heterodimer képzés is megfigyelhető. Minden monomerhez (ún. apoprotein) kapcsolódik egy nyílt láncú tetrapirrol természetü fitokromobilin festékmolekula, egy konzervált ciszteinen keresztüli tioéter kötéssel. Így jön létre az apoproteinből és kromofórból álló holoprotein.

A kromofór fényelnyelési tulajdonságainak köszönhetően a fitokrómoknak két alakjuk van: a vörös fényt elnyelö etiolált növényben nagy mennyiségben felhalmozódó és élettanilag hatástalan $\mathrm{P}_{\mathrm{r}}\left(\lambda_{\max }=660 \mathrm{~nm}\right)$ forma, valamint a távoli vöröset elnyelö aktív $\mathrm{P}_{\mathrm{fr}}\left(\lambda_{\max }=730 \mathrm{~nm}\right)$ forma (Franklin, 2005). A fitokrómok a sejtben $P_{r}$ alakban képződnek, majd vörös fény elnyelésekor átalakulnak $\mathrm{P}_{\mathrm{fr}}$ alakba. Ez az alak távoli vörös fény hatására képes visszakerülni az eredeti $\mathrm{P}_{\mathrm{r}}$ állapotba, amelybe egyébként idővel sötétben magától is visszaalakul. A fitokróm molekula karboxi-végén egy hisztidin-kinázokkal szekvencia homológiát mutató rész található, ezáltal a fitokróm fényszabályozott kinázként képes müködni.

A fitokrómok sötétben a sejtplazmában helyezkednek el, fény hatására pedig a sejtmagba vándorolnak, ahol fényfüggő gének kifejeződését szabályozzák (Kevei és mtsai, 2007b). A fitokrómok müködésük alapján két csoportba sorolhatók. Az I-es csoport tagjai (Arabidopsisban a PHYA) fényben gyorsan lebomlanak, fotolabilisak így legnagyobb mennyiségben a sötétben nőtt növényekben találhatók meg (Furuya és Schaefer, 1996). A PHYA szerepe elsősorban a csírázás megindításában és nagyon gyenge fényben a zöldülés szabályozásában van. A II-es csoportot a többi $(P H Y B-E)$ gén terméke alkotja. Ezek a fehérjék fényben nehezebben bomlanak, fotostabilak, ezért a zöld növények uralkodó 
fitokrómjai. A zöldülés folyamatát, a szár megnyúlását, az árnyékelkerülést és a virágzást szabályozzák.

A kriptokrómokat elsőként növényekben azonosították, mint a mikrobiális DNS fotoliázokkal nagyfokú rokonságot mutató fehérjéket (Cashmore és mtsai, 1999). Növényekben elsősorban a kék/UV-A-függő élettani folyamatok szabályozásában játszanak szerepet. Amino-végükön flavin-adenin-dinukleotid (FAD), illetve metil-tetrahidrofolát (MTHF) festékmolekulát kötni képes fotoliáz-szerü, karboxi-végükön pedig szerin/treonin kináz fehérjeelemet tartalmaznak (Lin és Shalitin, 2003). A kriptokrómok sejtmagi elhelyezkedésüek. Arabidopsisban két kriptokróm található, a CRY1 és a CRY2. A két fehérje fénystabilitása különbözik: kék fény hatására a CRY2 lebomlik, míg a CRY1 fehérje szintje nem változik (Yu és mtsai, 2007). Ennek megfelelően a CRY2 szerepe gyenge, míg a CRY1-é inkább erős fényben fontosabb.

A kriptokrómok és a fitokrómok együttesen játszanak szerepet a deetioláció folyamatának kialakulásában. A deetioláció során a csíranövények az ún. szkotomorfogenikus (sötétben fejlődés) állapotból fotomorfogenikus (fényen fejlődés) állapotba lépnek át, mely folyamat során a hipokotil megnyúlása abbamarad, szétnyílnak és kizöldülnek a sziklevelek, valamint fejlődésnek indul a gyökérzet. A cryl cry2 phyA phyB négyszeres mutáns fehér fényen nevelve a vad típusú etiolált növényhez hasonló morfológiát mutat. Azonban a cirkadián óra szabadon futó ritmusa, ami a sziklevelek ritmikus mozgásán figyelhető meg, megfelelően beállított marad. Szintén erőteljes cirkadián ritmus figyelhető meg a $p h y A$ phyB phyC phyD $p h y E$ ötszörös mutánsban is (Strasser és mtsai, 2010). Ez arra utal, hogy a szabadon futó ritmus kialakításához a fő fotoreceptoroktól jövő jelek nélkülözhetőek (Yanovsky és mtsai, 2000a). Folyamatos fehér fényben nevelt Arabidopsis növények esetében a szabadon futó periódus megközelítőleg 24 órás, míg folyamatos sötétben nevelt növények esetében a periódus 30 óra lesz néhány nap után. A deetiolációban föszerepet játszó fotoreceptorok mindegyike továbbít jelet a cirkadián óra felé. Folyamatos vörös fényben a PhyA és PhyB (valamint kisebb mértékben a Phy D és E is) rövidíti az óra periódusát, míg folyamatos kék fényben a periódus rövidüléséért a CRY1 és CRY2 felel. Két esetben lehetséges átfedés a fitokróm és a kriptokróm jelátviteli utak között. A fitokróm A olyan mennyiségben halmozódik fel gyenge fényviszonyok között, hogy kismértékü kék fény elnyelési képessége is nagyfokú periódus rövidülést okoz. Másodsorban pedig a CRY1-nek fontos szerepe van a gyenge vörös fényre adott vad típusú válasz kialakításában, holott az abszorbciós spektruma nem mutat fényelnyelést ebben a tartományban (Devlin és Kay, 2000). 
A ZTL, az LKP2 és az FKF1 egy UV-A és kék fény érzékelő fehérjecsalád tagjai (ADO/FKF/LKP/ZTL család). A bennük megtalálható LOV (LIGHT, OXIGENE OR VOLTAGE) domén a fototropinok LOV motívumával rokon. A LOV domén a PAS (PerARNT-Sim) szupercsalád tagja, és a fototropinok kék fény érzékelésében játszik szerepet (Ogura és mtsai, 2008). A LOV motívumot eredetileg olyan bakteriális fehérjékben azonosították, amelyek különféle környezeti tényezők, például fény, redox állapot, ill. feszültség érzékelésében vesznek részt. A LOV motívum flavin-mononukleotid (FMN) redoxfestéket köt. Található ezekben a fehérjékben egy F-box elem, ami olyan fehérjékre jellemző, amelyek az SCF (Skp1-Cul1-F-box) ubikvitin-ligáz komplex részeként fehérjék irányított lebomlásában működnek közre (Kipreos és Pagano, 2000). Az F-box fehérjék a lebontási folyamat kezdeti lépéseként a lebontandó célfehérjék felismerését és az ubikvitin-ligázhoz történő kapcsolását végzik. A harmadik motívum az ADO/FKF/LKP/ZTL család tagjaiban egy $\beta$-propeller szerkezetü fehérjefelismerő elem, a $\mathrm{KELCH}$, amelynek változékonysága lehetővé teszi a célfehérjék egyedi felismerését (Adams és mtsai, 2000).

A ZTL gén elrontása a cirkadián ritmus periódusának hosszabbodását okozza, ugyanakkor a növény fejlődési és fiziológiai folyamataira nincs számottevő hatással (Somers és mtsai, 2000). A periódus változása a fényerősségtől erősen függ, ami arra utal, hogy a ZTL-nek a fénybemenetben van szerepe. Az FKF1 a virágzás nappalhosszúság függésében kulcsszerepet játszó fehérje, a CONSTANS $(C O)$ gén napszakos kifejeződését szabályozza a CYCLING DOF FACTOR 1 (CDF1) lebontásán keresztül. Az $f k f 1$ mutánsban emellett a cirkadián ritmus is megváltozik (Imaizumi és mtsai, 2005). Az LKP2 túltermelése aritmiát okoz (Schultz és mtsai, 2001). Mint már korábban említettem, a ZTL kölcsönhat a TOC1 és PRR5 órakomponensekkel, serkentve proteoszóma általi degradációjukat. A ZTL továbbá kölcsönhat a GI fehérjével kék fényfüggő módon. Ez a kölcsönhatás stabilizálja mind a GI, mind a ZTL fehérjét, utóbbit megakadályozva ezáltal abban, hogy kölcsönhasson szubsztrátfehérjéivel. A GI kölcsönhat a ZTL homológ FKF1-gyel is, szintén kék fényfüggő módon, ebben az esetben a virágzási idő befolyásolásában szerepet játszó transzkripciós faktor stabilitását szabályozva (Sawa és mtsai, 2007).

A fotomorfogenikus, nem károsító hatású UV-B fény is hatással van a cirkadián órára, az óra beállító jelként képes érzékelni azt (Fehér és mtsai, 2011). A folyamatban részt vesz a növényi UV-B fotoreceptor az UV RESISTANCE LOCUS 8 (UVR8) és a CONSTITUTIVE PHOTOMORPHOGENESIS 1 (COP1) fehérje (Rizzini és mtsai, 2011). Az UVR8 a növényekben homodimerként előforduló, $\beta$-propeller szerkezetű fehérje, mely az emberi REGULATOR OF CHROMATIN CONDENSATION 1 (RCC1) fehérjével mutat nagyfokú 
hasonlóságot. Az UV-B fényt specifikus helyzetü triptofán aminosavakon keresztül érzékeli, jellegzetes kromofórt nem köt a fehérje (Rizzini és mtsai, 2011). A molekula UV-B fény hatására perceken belül monomerizálódik és a sejtmagba vándorol. Ott kölcsönhat a COP1 fehérjével (Favory és mtsai, 2009), valamint kötődik az általa szabályozott gének, többek között az ELONGATED HYPOCOTYL 5 (HY5) promoteréhez (Cloix és Jenkins, 2008). A cirkadián óra periódusa alacsony intenzitású UV-B hatására fényintenzitástól-függő módon rövidül, akárcsak a látható fény esetében. A HY5 és a vele homológ HY5 HOMOLOG (HYH) transzkripciós faktorokra nincs szükség ehhez a periódusváltozáshoz (Fehér és mtsai, 2011). Meghatározott időben adott UV-B pulzusokkal a cirkadián óra fázisa megváltoztatható a szubjektív éjszaka folyamán, a HY5 és HYH transzkripciós faktorokra nincs szükség a fázisváltáshoz. A beállítás az óragének transzkripciós aktiválásán keresztül történik (Fehér és mtsai, 2011). A cirkadián óra maga is visszahat az UV-B fénnyel indukált génekre az ún. kapuzási mechanizmus segítségével. A kapuzás szerepe abban nyilvánul meg, hogy a növények egy adott környezeti jelre nem egyforma mértékben reagálnak a nap folyamán. A HY5 UV-B indukcióját nem szabályozza a cirkadián óra, azonban a HYH átíródását igen (Fehér és mtsai, 2011).

\section{Jelátviteli utak}

A fényérzékelő fotoreceptorok és a központi óraelemek közt elhelyezhető elemekről még keveset tudunk. Az ELF3 és ELF4 fehérjék negatívan szabályozzák az óra bemeneti részét, valamint mindkettő szükséges a megfelelő, erőteljes ritmus fenntartásához (McWatters és mtsai, 2000; McWatters és mtsai, 2007). A COP1 és az ELF3 fehérjék együttesen felelősek a GI fehérje ubikvitinálásáért és lebomlásáért, ezt a folyamatot a kék fény a CRY2-n keresztül gátolja (Yu és mtsai, 2008). A COP1 a fotomorfogenezis egyik fontos negatív szabályozó eleme, egy ubiquitin ligáz, ami számos fotomorfogenezisben szerepet játszó fehérje $26 \mathrm{~S}$ proteaszóma általi lebontását szabályozza. A FAR RED ELONGATED HYPOCOTYL 1 és 3 (FHY1 és FHY3) hiányában távoli vörös fénnyel nem váltható ki fáziscssúszás (Yanovsky és mtsai, 2000b), így ezek a fehérjék is nélkülözhetetlenek az óra megfelelő működéséhez.

A TIME FOR COFFEE (TIC) szerepe elsősorban a cirkadián ritmusok periódusának és amplitudójának fenntartásában van (Ding és mtsai, 2007b). A tic mutánsokban minden kimenet sérül, de nem egyforma módon és mértékben. Ezekben a növényekben fényben és sötétben sem müködik megfelelően a cirkadián óra.

A SENSITIVITY TO RED LIGHT REDUCED 1 (SRR1) fehérje a vörös és fehér fényválaszok pozitív szabályozó eleme, és fontos szerepe van az óra sebességének szabályozásásban (Staiger és mtsai, 2003). Az srrl mutáns kevésbé érzékeny a vörös fényre, 
és számos egyéb, PHYB-függő fényválasza is sérült. Állandó körülmények között az srr1 szabadon futó ritmusának periódusa a vad típushoz képest rövidebb. Az SRR1 kifejeződését a vörös fény serkeni, ezért az SRR1 az óra fényérzékenységének beállításában vesz részt.

\section{A kimeneti oldal elemei}

A cirkadián óra számos fejlődési szakaszt befolyásol a növény életciklusa folyamán. Némelyek ezek közül napi rendszerességgel ismétlődnek és a cirkadián óra direkt szabályozása alatt állnak, mások pedig évszakosan ismétlődnek és a nappalhossz változás alapján szabályozódnak, amit szintén a cirkadián óra közvetít. A cirkadián óra már a növényi élet legkorábbi szakaszában is müködik. Arabidopsisban az órát már a magvak beáztatásával be lehet állítani. Csíranövényeket sötétben nevelve a beáztatást követő második naptól megfigyelhető az óragének kifejeződésében a cirkadián mintázat (Salomé és mtsai, 2008). Sok növényfajnál leírták már, hogy a virágzási időt a cirkadián óra határozza meg a nappalhosszúság mérésén keresztül, így időzítve azt a legmegfelelőbb évszakra.

\section{A csíranövények növekedése}

A cirkadián óra szabályozza Arabidopsis csíranövények szik alatti szárának megnyúlását: a megnyúlás mértéke nem egyforma a nap során. A fény és az óra együttesen alakítják ki a ritmikus mintázatot. A cirkadián óra kora éjszaka gátolja a szik alatti szár növekedését, de késő éjszaka nem (Nozue és mtsai, 2007). Ez a diurnális, vagyis napszakos, megvilágítástól függő növekedési mintázat aritmiás növényekben módosul, például a CCA1 túltermelő vagy az elf3 mutáns növényekben a növekedés serkentése az éjszaka folyamán végig megfigyelhető (Nozue és mtsai, 2007).

A PHYTOCHROME INTERACTING FACTOR 4 (PIF4) és 5 (PIF5) gének kifejeződését a cirkadián óra szabályozza. A maximum a nappal közepére esik, de a fény a fehérjék lebontását serkentve akadályozza a szár nappali megnyúlását, mivel a PIF4 és PIF5 fehérjék a megnyúlás fontos pozitív szabályzói. Az éjszaka elején viszont a cirkadián ritmus a minimumnál tart, ezért nincs elég fehérje. A külső (fény) és belső (cirkadián ritmus) tényezők időbeli elrendezésének eredménye, hogy csak az éjszaka végén van elég fehérje a megnyúlás beindításához. A fény gátló hatása nem teljes, mivel a megnyúlás mértéke periodikus marad állandó fényben is. Emiatt lehetséges az, hogy a cirkadián óra zavara rendszerint a szik alatti szár hosszának megváltozását is okozza (Dowson-Day és Millar, 1999). Az Arabidopsis növények hipokotilján megfigyelhető körkörös mozgás is cirkadián szabályozás alatt áll és a legnagyobb kitérést hajnalban mutatja (Niinuma és mtsai, 2005). 


\section{Szerv- és sejtszintü ritmikus folyamatok}

A növekedés során a cirkadián óra szabályozza az árnyékelkerülést. Ennek lényege a szomszédos növények jelenlétének érzékelése, ami fontos a fényforrásért folytatott küzdelemben. A szomszédos növényt a növény azáltal érzékeli, hogy az árnyékoló leveleken keresztül érkező fény vörös/távoli vörös aránya a közvetlen napfényéhez képest kisebb. A megváltozott arány érzékelésében a fitokrómoknak van elsődleges szerepe. Az óra hatása génexpressziós szinten nyilvánul meg, többek között a már emlitett $P I F$ transzkripciós faktorok és a PHYTOCHROME INTERACTING FACTOR 3-LIKE 1 (PIL1) szabályozásán keresztül. A beárnyékolt növények száruk és levélnyeleik megnyúlásával próbálják kompenzálni a kedvezőtlen fényviszonyokat (Salter és mtsai, 2003).

A közvetlen cirkadián szabályozás sejtszinten is megfigyelhető. Ilyen sejtszintű folyamat a gázcserenyílások nyitódása és záródása, amelyet a cirkadián órán kívül sok egyéb tényező (fény, hőmérséklet, páratartalom, $\mathrm{CO} 2$, hormonok, stb.) is szabályoz. Az éghajlati körülmények nagymértékben befolyásolják, hogy a gázcserenyílások mely napszakban nyitottak a legnagyobb mértékben. Arabidopsisban és a legtöbb mérsékelt égövi növényben a gázcserenyílások napközben kinyílnak, éjjel pedig bezáródnak (Somers és mtsai, 1998b). A nyitódás közvetlen szabályozásán túl a cirkadián óra a külső szabályozójelek (pl. a fény) hatását kapuzza (Gorton és mtsai, 1993).

A legismertebb napszakosan ismétlődő sejtszintü folyamatok a fotoszintézis és a szénmegkötés. Arabidopsisban számos, a fotoszintézis fény- és sötétszakaszában fontos gén kifejeződése áll cirkadián szabályozás alatt. Például az I-es és II-es fényelnyelő rendszer klorofill A/B-kötő fehérjéit (CHLOROPHYLL A-B BINDING PROTEIN, CAB) kódoló géneké, a klorofill szintéziséért felelős géneké (pl. protoporfirin IX magnézium kelatáz), valamint a $\mathrm{CO}_{2}$-megkötésben szerepet játszó rubisco enzim kis alegységét (RBCS) és a rubisco aktivázt (RCA) kódoló géneké (Harmer és mtsai, 2000). A fehérjék szintje és azok módosítása (például foszforillása) is cirkadián szabályozás alatt áll (Booij-James és mtsai, 2002).

A cirkadián óra a fejlődési faktorokat szabályozhatja például a promotereikben található szabályozó régiókon keresztül. A már említett esti elem a cirkadián óra által szabályozott gének promótereiben gyakran előforduló szakasz. Ugyanakkor ez az elem gyakori a hideg által szabályozott gének promotereiben is (Mikkelsen és Thomashow, 2009). Az esti elem csak néhány nukleotidban különbözik a CCA1-kötö helytől (CBS), amit elöször a $C A B 1$ gén promoterében azonosítottak (Michael és McClung, 2003). Ez azonban sokkal ritkábban fordul elő a cirkadián gének promóterében mint az esti elem. A $P R R 9$ gén promóterében található 
meg például egy ún. reggeli elem (Harmer és Kay, 2005), azonban a hozzá kapcsolódó transzkripciós faktor még ismeretlen.

\section{A nappalhosszúság szerepe}

A mérsékelt égövön az időjárás az év során előre jelezhetően változik és ezek a változások évente nagyjából ugyanúgy ismétlődnek. Az évszakok közötti legkiszámíthatóbb különbség azonban nem az időjárásban, hanem a nappalok hosszában figyelhető meg. Az időbeli tájékozódás legbiztosabb módja éppen ezért a nappalhosszúság változásának mérése, ami a cirkadián óra és a fényérzékelő rendszerek együttműködésén alapul.

A legismertebb évszakhoz kötött fejlődési folyamat az önfenntartó állapotról a reproduktív állapotra való átkapcsolás, amely visszafordíthatatlan, ezért különösen fontos annak pontos időzítése. A virágzás időzítésének szempontjából megkülönböztetünk hosszúnappalos és rövidnappalos, illetve nappalhosszúságra érzéketlen növényeket. A hosszúés rövidnappalos azt jelenti, hogy a növények akkor virágoznak inkább, ha a nappalok kellően hosszúak, illetve kellően rövidek.

A virágzást fehérjeszinten a nappalhosszúság azáltal befolyásolja, hogy egy cirkadián módon kifejeződő, fényérzékeny szabályozó fehérje kellően magas szintje kell, hogy elegendően hosszú ideig egybeessen a fényszakasszal a virágzás indukálásához (Searle és Coupland, 2004). Arabidopsisban ez a fényérzékeny fehérje a CONSTANS (CO) (SuárezLópez és mtsai, 2001). A CO feltételezhetően nem közvetlenül, hanem az ún. CCAAT-kötő segédfehérjékkel összekapcsolódva más gének átírását irányítja (Wenkel és mtsai, 2006). A cirkadián óra úgy szabályozza a $C O$ mRNS szintjét, hogy az hosszú nappalos körülmények között már a naplemente előtt emelkedni kezd, és magas szinten marad a következő reggelig. Rövid nappalon viszont csak éjszaka ér el magas szintet, és a keletkező CO fehérje a sötétben lebomlik. A nappal elején a fény a PHYB-n keresztül a CO fehérje lebomlását serkenti, a nap végén a PHYA és a CRY2 játszik szerepet a CO fehérje a távoli vörös és a kék fényfüggő stabilizálásában (Valverde és mtsai, 2004; Liu és mtsai, 2008). Ezért elegendő CO fehérje csak hosszú nappalon, a fényszakasz végén tud felhalmozódni. A nappalok hosszabbodásával a nap végén a $\mathrm{CO}$ fehérje mennyisége egyre hosszabb ideig marad magas szinten. Az egyik fő virágzásszabályozó gén, a FLOWERING LOCUS T (FT) átírásának beindításához a CO fehérje mennyiségének egy küszöbértéket kell meghaladnia. Az FT mRNS és fehérje a levelekből a csúcsi osztódó szövetbe transzportálódik, ahol beindítja a virágzást (Huang és mtsai, 2005). A virágzás szabályozása a rövidnappalos rizsben is hasonlóképpen zajlik, azonban a $C O$-nak megfelelő gén az FT-nek megfelelő gént hosszú nappalon nem serkenti, hanem gátolja. 
A cirkadián óra az önfenntartó állapotról a reproduktív állapotra való jutáson kívül egyéb fejlődési folyamatokat is a nappalhosszúság mérésén keresztül szabályoz. Ilyen a tápanyagraktározó szervek évszakos kialakulása (pl. burgonyagumó) és bizonyos mérsékelt égövi fák téli nyugalmi állapota. Ezeknek a folyamatoknak a szabályozása is a $C O$ és az FT gének müködéséhez kapcsolódik.

\section{A külső és belső idő összehangolásának jelentősége}

A müködőképes órával rendelkező Arabidopsis növények életképesebbek váltakozó fényviszonyok mellett, mint a ritmus nélküliek (Green és mtsai, 2002). Egy kísérlet során egy rövid és egy hosszú periódusú Arabidopsis mutáns növekedését és fejlődését hasonlították össze különböző hosszúságú napok alkalmazásával. Kiderült, hogy a rövid periódusú mutáns rövid napos (10 óra fény/10 óra sötét) míg a hosszú periódusú mutáns hosszú napos (14 óra fény/14 óra sötét) körülmények között növekszik hatékonyabban, bizonyítva a külső és belső ritmus összehangolásának fontosságát (Dodd és mtsai, 2005).

\section{A hormonok szerepe a cirkadián óra kimenetének szabályozásában}

Az abszcizinsav (ABA), a citokininek, a metil-jázmonát, a szalicilsav és az auxin mennyiségét egyaránt szabályozza a cirkadián óra (Covington és Harmer, 2007). A cirkadián óra szabályzó hatása a hormonok kifejeződésére nem meglepő, mivel a hormonok is a cirkadián óra kimeneti részét képezik. Érdekes módon az egyes hormonok is visszahatnak az órára, befolyásolják a periódust, az amplitudót vagy a fázist.

Arabidopsisban az etilén hormon kifejeződése napszakos ingadozást mutat. Az AMINOCYCLOPROPANE-CARBOXYLATE SYNTHASE 8 (ACS8) felelös az etilén egyik prekurzorának bioszintéziséért. Az etilén termelődését a cirkadián óra szabályozza, ez arra utal, hogy az etilénnek a kimeneti folyamatokban lehet szerepe. Azonban az etilén bioszintézis és jelátviteli mutánsok esetében a cirkadián rendszer zavara nem figyelhető meg (Thain és mtsai, 2004).

$\mathrm{Az}$ indolecetsav és indolecetsav-aszpartát szintje egyaránt ritmikus ingadozást mutat folyamatos fényviszonyok között. Mind az auxin szintézis, percepció és transzport esetében megfigyelhető a ritmikus változás. A virágszár eltávolításával a ritmikus szármegnyúlás, amiért az auxin felel, meggátolható, mivel ez a szerv az endogén auxin képződésének helye. Külsőleg adott auxin segítségével a ritmikus szármegnyúlás helyreállítható (Jouve és mtsai, 1999).

A gibberellinek és a cirkadián óra viszonya bonyolultabb. Az óra és a gibberellinek egyaránt szabályozzák a virágzási időt, de külön genetikai útvonalon (Boss és mtsai, 2004). 
A LIGHT INSENSITIVE PERIOD 1 (LIP1) szerepe a cirkadián óra szabályozásában

\section{A lip1 mutáció hatása a periódusra}

A lip1 mutációt egy mutáns szürés során azonosították Arabidopsis thaliana C24 ökotípusában (Kevei és mtsai, 2007a). Reggeli és esti kifejeződésű kimeneti géneket vizsgálva egyaránt rövid periódus figyelhető meg a lip1 mutánsban, sötétben és folymatos fényben is. Vad típusú növényekben a periódushossz a fényerösség növekedésével csökken. A lip1 mutánsokban a periódushossz gyakorlatilag változatlan marad minden vizsgált fényintenzitáson vörös és kék fényben is (5. ábra). A LIP1 negatív szerepet tölt be a cirkadián óra periódusának szabályozásában és fényintenzitás-függő módon képes szabályozni azt. A LIP1 hiánya tulajdonképpen a fény jelenlétét mimikálja, ezért tapasztalható rövid periódus a lip1 mutánsban alacsony fényintenzitáson. A rövid periódus a vizsgált óragének (CCA1, TOC1, LHY) mindegyikének esetében megfigyelhető lip1 mutánsban (Kevei és mtsai, 2007a).

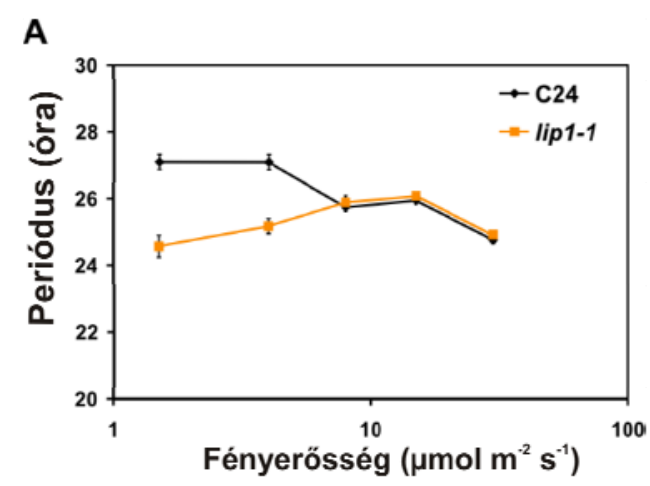

\section{5. ábra. A CCR2:LUC jelzógén periódusínak fényerổsségtốl való függése vỏräs és kék fẻnyben}

Anōyényeket 12 óra fểny/ 12 óra sötét ciklusokon nevelték 5 napig, majd folyamatos

(A) vörös, illetve

(B) kêk fënybe helyezték óket.

Luminométerrel 5 napig követték a markergén müködését.

B

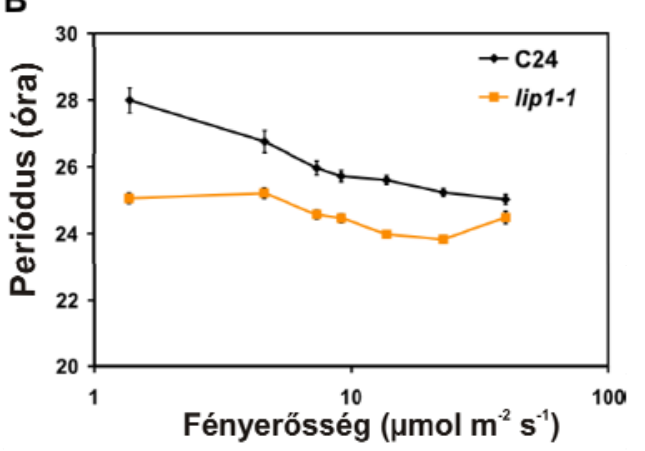

A periódusértékeket BRASS2 program segitségével számolták. A fényerōsséget logaritmusos skálán tüntették fel.

Az eredmények alapján két fontos dolog állapitható meg: egyrészt a lipl-1 periódusa alig érźkeny a fényre, másrészterős fênyben a lipl- $I$ és a vad tipus periỏdusa nem különbözik (Kevei és mtsai, 2007a).

\section{A lip1 mutánsok hajnalban érzékenyek a beállító fénypulzusra}

A cirkadián óra szabályozza saját érzékenységét a beállító fénypulzusokra. A szubjektív éjszaka első felében sokkal nagyobb fáziscsúszások válthatók ki lip1 mutánsokban, mint vad típusú növények esetében (6. ábra) (Kevei és mtsai, 2007a). 

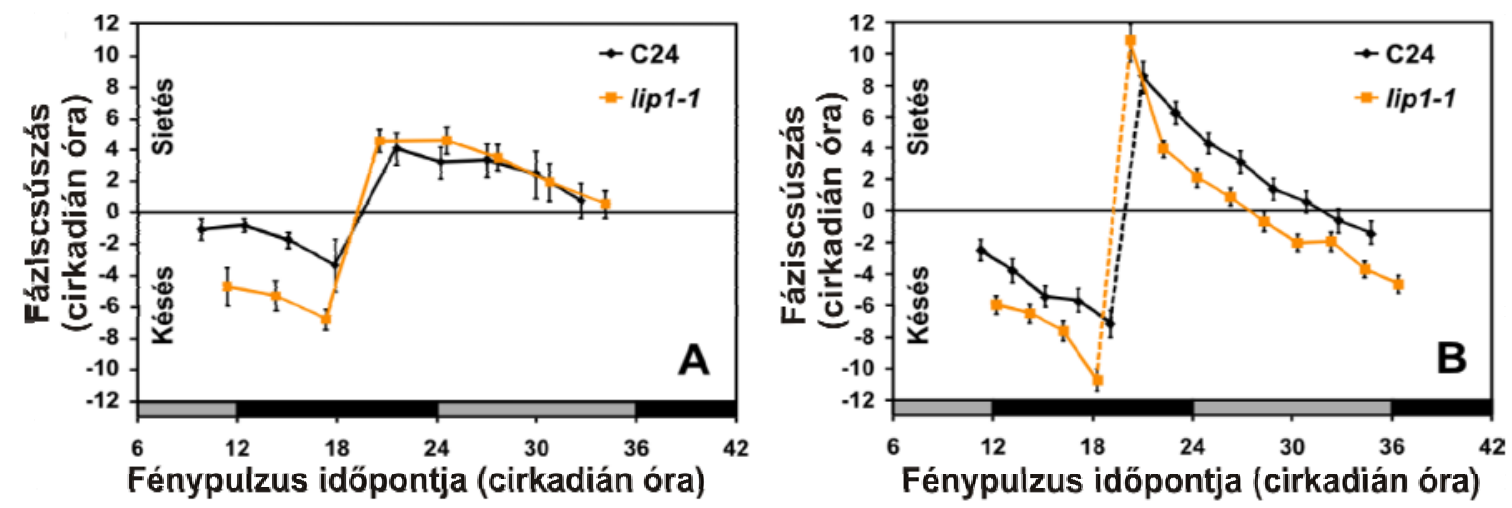

\section{6. ábra. A cirkadián óra beállíthatóságának vizsgálata fénypulzusokkal}

A CCR2:LUC markergént hordozó növényeket 12 óra fény/12 óra sötét ciklusokon nevelték 7 napig, majd folyamatos sötéthe helyezték őket. 3 óránként 1 órás, ugyanolyan erősségủ

(A) közepes vörös ( $18 \mu \mathrm{mol}$ foton $\left.\mathrm{m}^{-2} \mathrm{~s}^{-1}\right)$

(B) erös vörös $\left(150 \mu \mathrm{mol}\right.$ foton $\left.\mathrm{m}^{-2} \mathrm{~s}^{-1}\right)$ fénypulzust kaptak. A szürke sávok az időtengelyen a szubjektív nappalt jelölik. A lip 1-1-ben ugyanolyan fénypulzusokal nagyobb késéseket lehet kiváltani az éjszaka első felében, minta vad típusban.

A sietést kiváltó fényre a lip 1-1 vagy érzéketlenebb (B), vagy a vad típushoz hasonló (A) (Kevei és mtsai, 2007a).

\section{A LIP1 szerepe a fotomorfogenezis szabályozásában}

A mutánsban a kék és vörös fényre adott fotomorfogenikus válaszok megváltoznak, ez azonban nem a cirkadián óra hibás müködésének az eredménye (7. ábra). A LIP1 szerepet játszik a vörös és kék fény általi hipokotil megnyúlás gátlás szabályozásában, azonban a távoli-vörös fény által szabályozott folyamatban nincs szerepe. A lip1 mutáns növények szik alatti szára rövidebb, mint a vad típusé olyan nagy intenzitású vörös és kék fényben is, ahol a lip1 cirkadián fenotípusa már nem figyelhető meg. A cirkadián óra szabályozásában és a fotomorfogenikus folyamatokban betöltött szerepe a LIP1-nek ezért különválasztható (Kevei és mtsai, 2007a). 
A

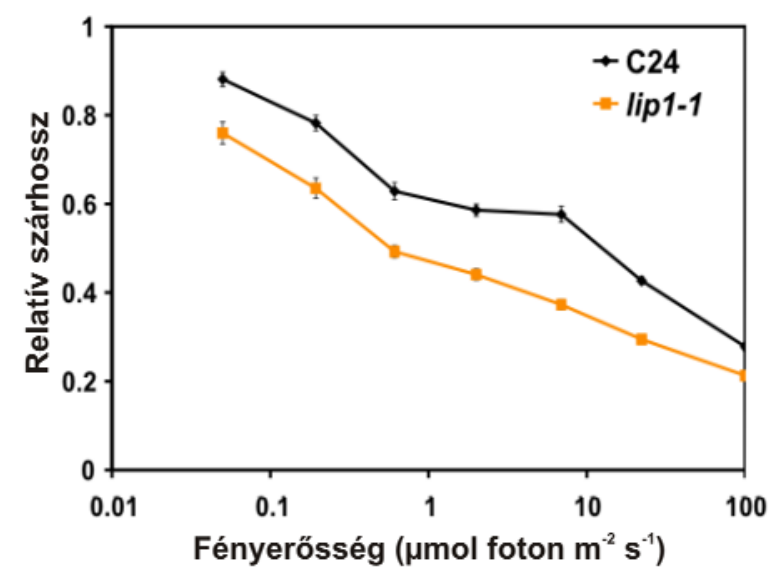

C

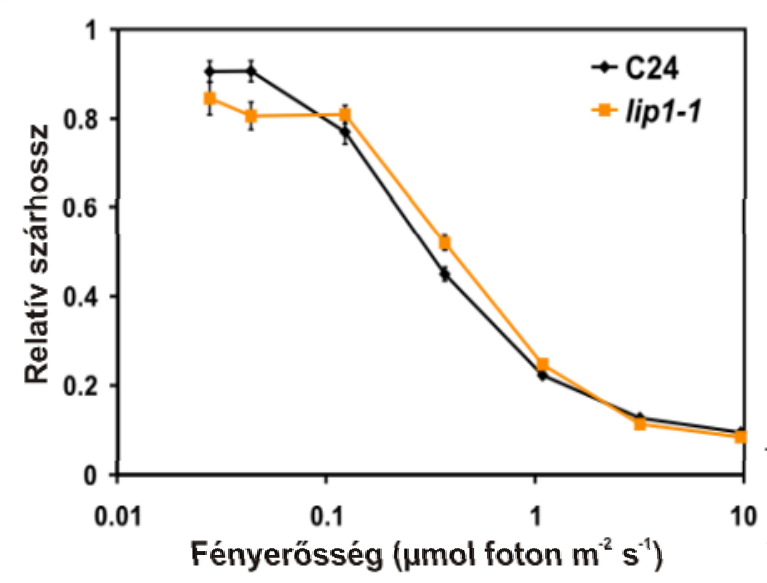

B

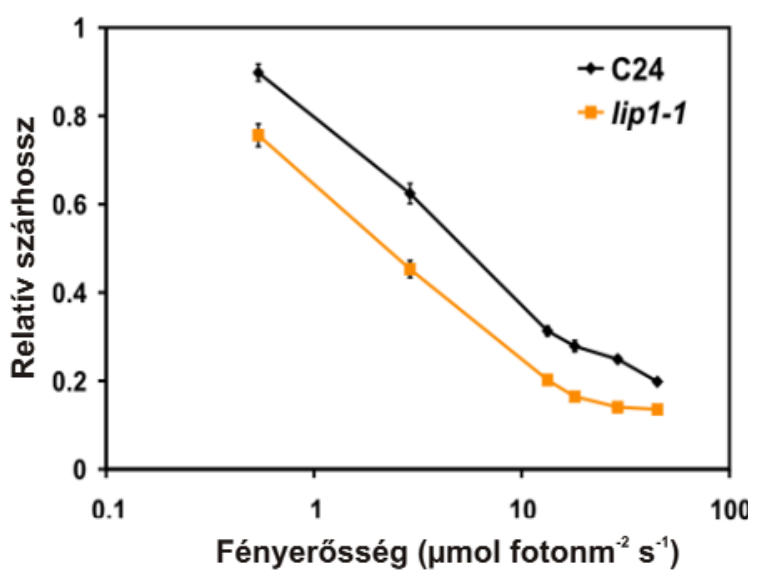

7. ábra. Ahipokotilhossz fényerősség-függése

A növényeket 4 napig nevelték monokromatikus fényen, állandó hőmérsékleten $\left(22^{\circ} \mathrm{C}\right)$. A szik alatti szár hosszát mérték, azonos ideig sötétben nevelt növények szárhosszára vonatkoztatták, majd az így kapott értékeket az alkalmazott fényerősség függvényében, logaritmusos skálán ábrázolták. A mintaszám $\mathrm{n}=50$, a hibahatárok a standard hibát jelölik (SE). A lipl-1 és a vad típusú növények hipokotiljának fényfüggő megnyúlása különbözik vörös (A) és kék (B) fényben, azonban távoli vörös (C) fënyben nem (Kevei és mtsai, 2007).

\section{A LIP1 gén egy atipikus kis GTP-kötő fehérjét kódol}

A LIP1 nagyfokú hasonlóságot mutat a kis GTP-kötő fehérjékkel (Vernoud és mtsai, 2003). A kis GTP-ázok 20-40 kDa molekulasúlyú fehérjék, amelyek guanozin-trifoszfát (GTP) kötésére képesek. Ezek a fehérjék alapállapotukban guanozin-difoszfátot (GDP-t) kötnek. Külső jel hatására egy nukleotidcserélő segédfehérje (GUANINE EXCHANGE FACTOR, GEF) a GDP-t GTP-re cseréli. A GTP-áz szerkezeti átrendeződésen megy keresztül, aminek eredményeképpen a célfehérjéivel képes kölcsönhatni. A nukleotidrögzítö segédfehérjék (GUANINE-NUCLEOTIDE DISSOCIATION INHIBITORS, GDI) a cserét gátolják. A GTP-kötött GTP-áz gyenge GTP-bontó képességgel is rendelkezik, ami lehetővé teszi az inaktív, GDP-kötött állapotba való visszaalakulást (Geyer és Wittinghofer, 1997; Paduch és mtsai, 2001). A kis GTP-kötő fehérjék változatos folyamatokat szabályoznak, például a növekedést, osztódást, sejtváz átrendeződését, sejtmozgást és a sejten belüli anyagmozgatást. A kis GTP-ázokat öt nagyobb és több kisebb családba sorolhatjuk. Az öt nagyobb család a Ras, Rho, Rab, Arf és a Ran (Takai és mtsai, 2001; Wennerberg és mtsai, 2005). Ezen kívül egyre több olyan GTP-ázt írnak le, amelyek sem szerkezetükben, sem müködésükben nem hasonlítanak a klasszikus kis GTP-kötő fehérjékre (Leipe és mtsai, 2002). 
Növényekben Ras és a Rho család teljesen hiányzik. Helyettük a RHO OF PLANTS (ROP) molekulák vannak jelen. Számos élettani folyamatot szabályoznak, például a sejtváz átrendeződésben van szerepük (Settleman, 2005). Növényekben a Plant RHO Nucleotid Exchanger (PRONE)-elemet tartalmazó RopGEF-ek végzik a nukleotidcserét (Berken és mtsai, 2005).

A LIP1 fehérjében több olyan motívum is található, ami a klasszikus kis GTP-kötő fehérjékre nem jellemző, valamint több konzervált aminosav esetében is eltéréseket mutat. Például a 94-es pozíciójú, igen konzervált glutamin (Vetter és Wittinghofer, 2001) helyett hisztidin található benne. Ennek a glutaminnak a mutációja a GTP-áz aktivitás elvesztéséhez vezet a klasszikus GTP-kötő fehérjék esetében, bár a GTP-kötő képességük megmarad. A C és az $\mathrm{N}$ terminálison másodlagos fehérje módosulásokért felelős szakaszok is hiányoznak a LIP1 molekuláról, melyek lipidmódosításokon keresztül a sejthártyához való kötődésért felelősek más kis GTP-kötő fehérjék esetében. A LIP1 a kis GTP-kötő fehérjék egy új alcsaládjába sorolható, GTP-kötő és bontó aktivitással is rendelkezik in vitro. Növények esetében ez az első kis GTP-kötő fehérje, amit kapcsolatba hoztak a cirkadián órával.

\section{Az abiotikus stressz-válaszokban szerepet játszó jelátviteli utak}

Az alacsony, illetve magas hőmérséklet, a szárazság és a magas só koncentráció olyan általános stressz körülmények, melyek károsíthatják a növények fejlődését és terméshozamát. A környezeti stresszre adott válasz molekuláris és sejtszintü folyamatainak megértése intenzíven kutatott tudományterület. A környezeti változásokra válaszként szignáltranszdukciós kaszkád útvonalak aktiválódnak, amelyek a fiziológiai és biokémiai folyamatokat koordinálják és az adaptációhoz szükségesek.

Egy általános szignál transzdukcó a szignál érzékelésével kezdődik, amit másodlagos hírvivő molekulák generálása követ (pl. $\mathrm{Ca}^{2+}$, reaktív oxigéngyökök (ROS), inozitolfoszfátok). A másodlagos hírvivők hatására az intercelluláris $\mathrm{Ca}^{2+}$ szint tovább változik, amit $\mathrm{Ca}^{2+}$ szenzorok érzékelnek. Ennek következményeképpen foszforillációs kaszkád indul meg, amit a fő stressz-válasz gének indukciója követ (Xiong és mtsai, 2002).

\section{Ionikus stressz}

A só stressz során a növények ionikus homeosztázisa sérül, ami a $\mathrm{Na}^{+}$toxikus felhalmozódásához vezet a citoplazmában, valamint olyan esszenciális ionok egyensúlyának felborulásához, mint például a $\mathrm{K}^{+}$. A SALT OVERLY SENSITIVE (SOS) útvonal nélkülözhetetlen a citoplazma megfelelő ion-koncentrációjának fenntartásához és a só stressz tolerálásához (Zhu, 2002). Az ozmotikus és ionikus stresszre adott válaszok több egymást 
követő, illetve párhuzamos lépésből adódnak össze (Yamaguchi-Shinozaki és Shinozaki, 1994). A korai válaszok során a sejten belüli $\mathrm{Ca}^{2+}$ szint megemelkedik, ez a sejtek ionháztartásának SOS fehérjék által szabályozott változásához vezet. $\mathrm{A} \mathrm{Ca}^{2+}$ szint megemelkedése és más másodlagos hírvivő molekulák megjelenése (foszfolipidek, reaktív oxigén gyökök) olyan kináz jelátviteli utakat aktivál, amik a korai stressz-válasz gének transzkripcióját serkentik. Az SOS3 egy $\mathrm{Ca}^{2+}$-kötő fehérje, ami a só stressz által indukált kalcium szignált érzékeli. Az SOS2 egy szerin/treonin típusú kináz, az SOS1 pedig egy $\mathrm{Na}^{+} / \mathrm{H}^{+}$antiporter a plazmamembránon (Shi és mtsai, 2000). A só stressz során az SOS2 és 3 komplexet képezve foszforilálja és aktiválja az SOS1 antiportert (Batelli és mtsai, 2007). Az SOS1 szerepe a $\mathrm{Na}^{+}$sejtből való eltávolítása.

\section{Szárazság és ozmotikus stressz}

Az ABA vízhiányos körülmények között termelödik, és fontos szerepet játszik a szárazság és a magas só koncentráció tolerálásában. Külsőleg adott ABA számos dehidrációban és hideg stresszben szerepet játszó gén kifejeződését serkenti. Azonban több olyan gént is leírtak, amelyek szárazság és hideg stressz esetén indukálódnak, azonban külsőleg adott ABA kezelés hatására nem (Zhu, 2002).

A COLD RESPONSIVE GENES/RESPONSIVE TO DESICCATION család tagja a COR78/RD29A szárazságra, hidegre és exogén ABA kezelésre egyaránt indukálódó gén (Yamaguchi-Shinozaki és Shizonaki, 1993). Azonban ABA inszenzitív mutánsokban és ABA bioszintézis mutánsokban is kimutatható indukciója, ezért az ABA-függő és -független útvonalnak is része. A promóterében található DRE-elem (DEHYDRATION RESPONSIVE ELEMENT) fontos cisz-ható eleme az ABA független válaszoknak, és más szárazság, illetve hideg stresszre indukálódó gének promoterében is megtalálható (Yamaguchi-Shinozaki és Shizonaki, 1994). Az elemhez kötő transzkripciós faktorok a C-REPEAT BINDING FACTOR/DEHYDRATION RESPONSIVE ELEMENT BINDING 1 és 2 (CBF/DREB1 és 2). Előbbinek a hideg stressz-válaszokban, utóbbinak a szárazság stresszben van szerepe. Nyolc DREB2 homológot írtak le, ezek közül a DREB2A és B a szárazság stressz fö transzkripciós faktorai (Sakuma és mtsai, 2002). Az ABA-válaszelem (ABA RESPONSIVE ELEMENT, ABRE) az ABA-függő útvonal fontos cisz-ható eleme. Két ABRE motívum található például az RD29B esetében, melyekhez ABRE-kötő faktorok (ABRE-binding factor, ABF) kötnek és aktiválják az ABA-függő kifejeződést (Choi és mtsai, 2000). A MYC és MYB fehérjék szintén az ABA-függő útvonal aktivátorai, szintézisüket az endogén $\mathrm{ABA}$ koncentráció növekedése serkenti (Abe és mtsai, 2003). A RESPONSIVE TO ABA (RAB18) az ABA-függő útvonal részeként indukálódó ozmoprotektáns fehérje. Egyaránt serkenti 
kifejeződését szárazság és a só stressz, de a cukor és a foszfáthiány is (Cieszko és Kleczkowski, 2002). Kifejeződésének serkentésében fontos szerepe van az intracelluláris $\mathrm{Ca}^{2+}$ koncentráció változásának (Ghelis és mtsai, 2000).

\section{A cirkadián óra szerepe a stressz-folyamatok szabályozásában}

A cirkadián órának rendkívül fontos szerepe van a stressz-válaszok időbeli szervezésében. A fény ugyan elsődlegesen energiaforrás a növények számára, de a túl sok fény káros lehet a fényelnyelő rendszerekre és a DNS-re is. A fény által okozott károk csökkentése érdekében a növényekben már a napfelkelte elött megkezdődik a fényvédő molekulák (fenilpropanoidok) képződéséért felelős enzimek génjeinek kifejeződése (Harmer és mtsai, 2000). Nappal a sok fény mellett a magas hömérséklet és a szárazság, valamint a talajvízben oldott anyagok koncentrálódása miatt a só és az ozmotikus stressz okozhat problémát. A gázcserenyílások nyitódását, valamint ioncsatornák és pumpák génjeinek kifejeződését is időzíti az óra ilyenkor. Éjszaka a hideg jelenti a legnagyobb gondot. Erre felkészülendő a növényekben a. deszaturázok szintje kezd emelkedni már naplemente előtt, a membránok fagyállóképességét növelve. A növények a cirkadián óra kapuzási folyamata miatt nem azonos mértékben érzékenyek a hidegre és a melegre a nap során: kimutatták például, hogy a gyapot növény a hidegre a nap elején érzékenyebb, a melegre pedig a nap végén (Rikin és mtsai, 1993).

A vegetatív növekedési fázisban a cirkadián óra szabályozza a fény mellett a hőmérsékletváltozásokra adott válaszokat is. Az olyan fiziológiás határon kívül eső hőmérséklet, mint a fagyás vagy a hőség stressz-válaszokat idéznek elő. A fagytürésben szerepet játszó CBF1/DREB1 családba tartozó transzkripciós faktorok ritmikus kifejeződést mutatnak a nap folyamán (Fowler és mtsai, 2005), mivel cirkadián kontoroll alatt állnak. Az óra képes gátolni a $C B F$ gének válaszképességét hideg stresszre a nap folyamán, ezáltal a maximális fagytürő képességet éjszakára időzíteni, amikor arra a legnagyobb szükség van. A CBF3 esetében kimutatták, hogy kifejeződését a délután folyamán a TOC1 gátolja, a PIF7 transzkripciós faktorral történő kölcsönhatás révén (Kidokoro és mtsai, 2009).

Az órát érintő mutációk is hatással lehetnek a hidegtürő képességre. A GI gén mutációja fokozott érzékenységet okoz a hideggel szemben és ez a hatás a CBF útvonaltól független (Cao és mtsai, 2005). A gi mutáns megnövekedett toleranciát mutat oxidatív stresszel szemben, ami emelkedett szuperoxid-dizmutáz és aszkorbinsav-peroxidáz szinttel párosul (Kurepa és mtsai, 1998; Cao és mtsai, 2005). A GI szerepét leírták továbbá a keményítő metabolizmusban is, a gi mutánsban a keményítő felhalmozódása figyelhető meg, pedig a GI maga nem egy keményítő metabolizmusban részt vevő enzim (Eimert és mtsai, 1995). Megfigyelhető továbbá a mutánsban az egyszerü szénhidrátok felhalmozódása is (Messerli és 
mtsai, 2007). Az lhy ccal dupla mutáns enyhén érzékeny só, ozmotikus és hő-stresszre (Kant és mtsai, 2008).

$\mathrm{Az}$ óra és a szárazság-stresszre adott válasz közti kapcsolat már bizonyított az $\mathrm{ABA}$ jelátviteli útvonal által (Legnaioli és mtsai, 2009). Nem meglepő az a tény, hogy a szárazság, só és ozmotikus stresszben fontos szerepet játszó gének nagy része szintén cirkadián kontroll alatt áll (Covington és mtsai, 2008). Emelkedett TOC1 szint a szárazságtürő képesség csökkenéséhez vezet, míg csökkent TOC1 szint emelkedett szárazságtürést okoz. Ez a jelenség összefüggésbe hozható azzal, hogy a TOC1 képes az ABA-BINDING PROTEIN/GENOME UNCOUPLED 5 (ABAR/GUN5) gén promoteréhez cirkadián módon kötni, ezzel a gén kifejeződését az este folyamán gátolni. Az ABAR/GUN5 szerepe a szárazságtürésben a gázcserenyílás méretének szabályozása. Nemcsak az óra képes az ABA függő útvonalat szabályozni, hanem a hormon is képes akut módon befolyásolni a TOC1 gén kifejeződését (Legnaioli és mtsai, 2009). Ez a visszacsatolás biztosítja az ABA jelátvitel és a sztómanyitás megfelelő időzítését és érzékenységét. Az ABA-val indukálható gének kifejeződése eltérő a nap folyamán, továbbá az ABA prekurzorainak, illetve a bioszintézisében szerepet játszó enzimek egy részének kifejeződése is cirkadián szabályozás alatt áll (Covington és mtsai, 2008). Az ABA egyes prekurzorai, a bioszintézisben résztvevő gének és több ABA jelátvitelben résztvevő gén is diurnális kifejeződést mutat, valamint transzkripciójuk megváltozik cirkadián óra mutánsokban, például a prr9 prr7 prr5 tripla mutánsban vagy a CCA1 fehérjét túltermelö növényekben (Fukushima és mtsai, 2009). Az aritmiás prr5 prr 7 prr 9 tripla mutánsban ozmolitok, $\mathrm{ABA}$, antioxidánsok és a trikarbonsav ciklus intermediereinek emelkedett szintje figyelhető meg (Fukushima és mtsai, 2009; Nakamichi és mtsai, 2009). A prr9 prr7 prr5 háromszoros mutánsban az ABA-független DREB1/CBF magasabb szinten fejeződik ki, ez fokozott só-, szárazság- és hidegtürést okoz (Nakamichi és mtsai, 2009), míg ugyanez a gén alacsonyabb szinten fejeződik ki a ccal lhy kétszeres mutánsban, ezért ezek a növények érzékenyebbek a hideg és só stresszre (Kant és mtsai, 2008; Dong és mtsai, 2011).

\section{Endoreduplikáció}

Az eukarióta sejtek osztódása rendszerint a mitotikus sejtciklussal megy végbe, ahol a sejt DNS tartalma állandó marad az egyes osztódási ciklusok után. A sejtciklus sokféleképpen módosulhat attól függően, hogy az adott sejttípusnak milyen környezeti vagy fiziológiai követelményeknek kell megfelelnie (Jakoby és Schnittger, 2004). Egy extrém példája ennek a virágos növények endospermiumának első osztódása, ahol a megtermékenyítést követően a központi sejtben csupán a sejtmagok sorozatos osztódása történik meg citokinézis nélkül, ezzel 
sokmagvas struktúrát, azaz szincíciumot hozva létre (Boisnard-Lorig és mtsai, 2001). Egy másik példa a szkotomorfogenezis során a hipokotil nagymértékü megnyúlása, ahol a sejtméret növekedése nem jár együtt sejtosztódással (Gendreau és mtsai, 1997).

Az endoreduplikáció során a sejt a DNS tartalmát folyamatosan duplikálja, poliploid (több kromoszómakészlettel rendelkező) sejtet hozva létre. A folyamat növényi és állati sejtekben egyaránt megfigyelhető, főként a magas metabolikus aktivitású sejtekre jellemző. Az endoreduplikáció lehetőséget nyújt a DNS templát mennyiségének növelésére, ezáltal a génexpresszió hatékonyságának növelésére. Az endoreduplikáció során létrejött magas ploidiájú sejt gyakorlatilag funkcionálisan több diploid sejtnek felel meg (D’Amato, 1964). Jellemzően az endoreduplikálódó sejtek nagyobb méretűek, mint a normálisan osztódó sejtek. Az endoreduplikáció gyakran figyelhető meg gazdaságilag fontos növényi szerveknél. Például raktározó képleteknél, mint a búzaszem endospermiuma (Sabelli és Larkins, 2009) vagy a pillangósvirágúak nitrogén-fixáló gyökérgümőinél (Kondorosi és Kondorosi, 2004). Arabidopsis esetében az endoreduplikáció megfigyelhető felszíni szervek szőrképleteinek sejtjeiben (Hülskamp és mtsai, 1994), de a sziklevelek bőrszöveti sejtjeiben is gyakran megfigyelhető emelkedett kromatintartalom (Galbraith és mtsai, 1991).

Ahogyan az endoreduplikációra képes sejtek is sokfélék, az endoreduplikáció maga is többféleképpen mehet végbe. Az endomitózis a mitózis egy formája, melyben a DNS megkettőződése után a sejt nem válik ketté, olyan sejtet eredményezve, melynek kromoszómaszáma jóval több, mint a normális. A parciális endoreduplikáció esetében pedig az újra replikálódások száma korlátozott.

A szabályos mitotikus ciklus négy szakaszból áll: két ún. növekedési fázis (G1 és G2), a DNS replikáció (S fázis) és a kromoszómák szétválása (M fázis) (Gutierrez, 2009). Az endoreduplikáció során a genom amplifikációja a kromatin kondenzációja és szegregációja nélkül, valamint citokinézis nélkül következik be. Normál esetben a kromoszómák egyszer osztódnak egy sejtciklus folyamán. A sejtciklus során a G1-S és a G2-M fázisátmeneteket a ciklin-dependens kinázok (CYCLIN DEPENDENT KINASE, CDK) szabályozzák, mégpedig úgy, hogy a sejtciklus egyes fázisaiból más fázisokba való átlépést szabályozó fehérjéket foszforilálnak (Gutierrez, 2009). Arabidopsisban két csoportjukat különböztetjük meg, az Aés B-típust. Az A-típusú CDK a G1-S és a G2-M fázisátmenetek szabályozásában fontos. A B-típus eukarióták közül csak a növényekben fordul elö. A B-típusba tartozik a CDKB1 és CDKB2, előbbi a sejtciklus elején már kifejeződik, utóbbi pedig a G2-M átmenet alatt. Mindkettő a G2-M átmenetben játszik fontos szerepet. 
Működésükhöz és aktiválódásukhoz ciklinekre van szükség. Arabidopsisban három ciklin típust különböztetünk meg. A CYCLIN A (CYCA) az S fázis fenntartásában és a G2-M átmenetben fontos, a CYCB a G2-M átmenetben és a mitózis fenntartásában játszik szerepet, a CYCD pedig összehangolja a környezeti jeleket és a sejtciklus során végbemenő szignalizációs útvonalat. A ciklinek különböző mennyiségben fejeződnek ki a sejtciklus során, attól függően, hogy melyik fázisban tart éppen a ciklus (Wang és mtsai, 2004).

\section{Az endoreduplikációs ciklusba lépés}

Az endoreduplikáció során a normál mitotikus ciklus megváltozik. Az endoreduplikációs ciklus fenntartásához a ciklinek aktivitását megfelelően alacsony szinten kell tartani, hogy a mitózist még ne serkentsék. Ez például a mitotikus és premitotikus szabályozó faktorok müködésének befolyásolásán keresztül valósulhat meg (Jakoby és Schnittger, 2004). Arabidopsis levél fejlődése során a mitotikus $C D K$ és ciklin gének transzkripciójának csökkenése egybeesik az endociklus kezdetével (Boudolf és mtsai, 2004). Az endociklus kezdetének első lépése lehet a CDKB1 aktivitásának részleges vagy teljes csökkentése a G2M átmenet során. Egy másik lehetséges módja az endociklusba lépésnek az ún. hármas ismétlődésű MYB fehérjék (MYB3R) ciklinek általi foszforilálódásának elmaradása. Ezek a fehérjék a G2-M átmenet során a kifejeződő gének transzkripcióját szabályozzák, többek között a B- típusú ciklinekét is (Ito és mtsai, 2001). Így a MYB3R foszforilálódásának hiánya végső soron az M fázisban fontos gének kifejeződésének elmaradásához vezet (Wildermuth, 2010). A mitotikus CDK-ciklin komplex inaktiválásának egy lehetséges módja a ciklin lebontása az ANAPHASE PROMOTING COMPLEX/CYCLOSOME (APC/C) segítségével, ami egy E3 ubiquitin ligáz és a fehérjék 26S proteaszóma általi lebontásában van szerepe.

A mitotikus ciklinek aktivitása egy harmadik útvonalon is csökkenthető, CDK inhibitorok (CKI) közremüködésével. A SIAMASE-RELEATED családba tartozó SIAMASE (SIM) gén kódolja azt a CKI fehérjét, ami az endoreduplikációs ciklusba lépésért felel (Churchman és mtsai, 2006).

\section{Az endoreduplikációs ciklus fenntartása}

Az endociklusba lépés folyamata sokkal jobban ismert, mint az, ahogyan a ciklus fennmarad. Feltehetően minden egyes endociklikus körbe való belépés alapja a CDK aktivitás ciklikus változása. A ciklus fenntartásában feltehetőleg szerepe van a KIP-RELATED PROTEIN (KRP)/INTERACTOR OF CDK családba tartozó KRP1 és 2 fehérjéknek, melyek a SIM-hez hasonlóan CKI funkciót töltenek be. Ezek a fehérjék a CDKA-CYCD komplexet gátolják, túltermelésük mitotikusan aktív sejtekben a sejtosztódást gátolja és az endoreduplikációt serkenti (Verkest és mtsai, 2005). A KRP-k dózis-függő módon hatnak, kis 
mennyiségben a mitotikus sejtciklust gátolják, nagy mennyiségben pedig az endoreduplikációt serkentik. Matematikai modellek alapján feltételezhető, hogy az endociklus fenntartásához elegendő a KRP-k ciklikus felhalmozódása, ami periodikusan gátolja a CDK aktivitást a G1-S átmenetben, valamint a SIM fehérjék által kifejtett specifikus gátló hatást a G2-M átmenetnél (Roodbarkelari és mtsai, 2010).

Az E2F/DP családba olyan transzkripciós faktorok tartoznak (E2Fa, E2Fb, E2Fc), amelyek a DNS replikációhoz szükséges gének kifejeződését befolyásolják. Az E2F/DP-szerü fehérjék (E2Fd, E2Fe, E2Ff) olyan transzkripciós faktorok, amelyek az osztódó sejtek differenciációs eseményeit szabályozzák, így az endoreduplikációt és a sejt növekedését is. Az E2Fe/DEL1 az endociklusba lépés fontos negatív regulátora. Az osztódó szövetekben a DEL1 mennyisége az E2Fb-től és E2Fc-től függ. Az E2Fb a DEL1 génkifejeződés aktivátora, míg az E2Fc a represszora. Az E2Fc fényben az SCF ubikvitin-ligáz komplex által ubiquinfüggő módon gyorsan lebomlik (del Pozo és mtsai, 2002). Az E2Fb sötétben bomlik le, ez a folyamat a COP1 által szabályozott. Ezért fényben a DEL1 felhalmozódik és az endociklusba való lépést gátolja, míg sötétben inaktiválódik, így az endociklus végbemehet. A DEL1 fényszabályozása az E2Fb és E2Fc egyensúlyán keresztül valósul meg (Berckmans és mtsai, 2011).

\section{Fiziológiai tényezők hatása az endoreduplikációra}

A sötétben nevelt Arabidopsis csíranövények esetében a fény hiánya a hipokotil sejtjeiben egy extra endoreduplikációs ciklust eredményez (Gendreau és mtsai, 1997). Fotomorfogenikus mutánsok vizsgálata során kiderült, hogy a sötét által indukált endoreduplikációban a fitokrómoknak fontos szerepe van, és hogy ez a szkotomorfogenikus fejlődés fontos lépése (Gendreau és mtsai, 1998). Az endociklus hozzájárulhat a hipokotil sejtjeinek megnyúlásos növekedéséhez, de a DNS tartalom növekedése és a sejt méretének növekedése közti összefüggés nem teljesen tisztázott még. Arabidopsis növények árnyékban nőtt leveleiben a DNS tartalom csökkenése figyelhető meg (Cookson és Granier, 2006). A levelek és a hipokotil esetében tehát ellentétes hatás figyelhető meg az endoreduplikációra a fényviszonyok tekintetében. A ploidia szám növekedése előnyt jelent vízhiányos körülmények között. A vízhiány következtében a vad típusú Arabidopsis növények esetében a sejtméret és a DNS tartalom csökkenése figyelhető meg, ami a levélméret csökkenéséhez vezet. Magasabb endoreduplikációs szintet mutató transzgenikus növények esetében azonban a ploidia függvényében sejt-, illetve szervméret növekedés figyelhető meg (Cookson és Granier, 2006). 
A magasabb ploidia előnyt jelent az UV-B sugárzással szemben is. Akut UV-B kezelés következtében vad típusú Arabidopsis növények esetében sejtszám és sejtméret csökkenés figyelhető meg. Azok a növények azonban, amelyek az endoreduplikációs ciklus egyik regulátorára az $E 2 \mathrm{Fe} / \mathrm{DEL} 1$-re mutációt hordoznak, a sejtméret és a sejtszám csökkenése nem olyan mértékü, mint a vad típusban (Radziejwoski és mtsai, 2011).

\section{A fitokrómok szerepe az endoreduplikáció szabályozásában}

Mint már említettem, Arabidopsisban többek között a hipokotil sejtjeiben figyelhető meg az endoreduplikáció. A csírázás során két endociklus zajlik le úgy, hogy nem elözi meg érdemi sejtméret növekedés. A sejtméretet drámaian csökkentő cpm17 mutációnak például nincs hatása a harmadik endociklus kimenetelére. A cpm17 egy brasszinoszteroid bioszintézis mutáns, melynek szik alatti szára folyamatos sötétben jóval rövidebb, mint a vad típusé, viszont DNS tartalma csaknem azonos vele. Ez arra utal, hogy az endoreduplikáció és a sejméret szabályozása között nem egyszerü visszacsatolásos kapcsolat van (Gendreau és mtsai, 1998). Fitokróm mutánsokkal végzett kísérletek igazolták, hogy a harmadik endociklus hiánya távoli-vörös fényben a fitokróm A jelátviteli utakhoz köthető, valamint kisebb mértékben ugyan, de vörös és fehér fényben a fitokróm B-hez. Utóbbi esetben feltehetőleg egyéb fény-stabil fitokrómok szerepe sem zárható ki (Gendreau és mtsai, 1998). A fitokrómok által közvetített fényjel egyaránt limitálja a sejtméret növekedését és az endoreduplikációt, azonban a két jelenség közt feltehetőleg bonyolultabb kapcsolat van az egyszerü ok-okozati összefüggésnél.

\section{A cirkadián óra és az endoreduplikáció kapcsolata}

Növények esetében ezidáig nincs olyan irodalmi adat, ami megerősítené a cirkadián óra és az endoreduplikáció közötti kapcsolatot. Emlős sejtek esetében is csak nemrégiben írtak le kapcsolatot a sejtciklus és a cirkadián óra között. A sejtciklus bonyolult hálózatának sok eleme áll cirkadián szabályozás alatt emlős sejtekben. Például a ciklin-dependens kinázok közül a Wee kináz, ami a G2-M fázisátmenetet gátolja, a CLOCK/BMAL1 komplex (Gekakis és mtsai, 1998) szabályozása alatt áll (Matsuo és mtsai, 2003), ami az emlős cirkadián óra egyik kulcseleme. Kimutatták, hogy a sejtciklus is képes 24, illetve 48 órás periódussal ismétlődni. A sejtciklus periódusának beállítása nem mindig áll cirkadián szabályozás alatt, egy bizonyos beállító tartományon kívül a két ritmus szétkapcsolódik, illetve a sejtciklus olyan rendhagyó ciklikusan ismétlődő folyamatra válthat át, mint például az endoreduplikáció. A modell szerint a 24, illetve 48 órás ciklusra való beállás akkor következhet be például, amikor bizonyos növekedési faktorok szintje egy kritikus érték alá csökken (Gérard és Goldbeter, 2012). 
Allotetraploid (olyan poliploid alak, ami két különböző genomú diploid faj hibridizációja és a hibrid kromoszóma-garnitúrájának kétszereződésével jön létre) Arabidopsis növények esetében írták le, hogy a bennük magasabb kifejeződést mutató kb. 130 gén közel egyharmada tartalmaz vagy CCA1-kötő vagy esti elemet (Wang és mtsai, 2006; Chen, 2010). Ezek egy része a klorofill bioszintézisében szerepet játszó gén, más részük pedig a cukrok transzportjában, illetve a keményítő metabolizmusban játszik szerepet (Ni és mtsai, 2009). Ezek az adatok közvetetten a cirkadián óra és az endoreduplikáció közti kapcsolatra utalnak. 


\section{CÉLKITÜZÉSEK}

A cirkadián óra részletes tanulmányozása során egyre több órakomponensről és óra kapcsolt elemről derül ki, hogy pleiotróp funkciókkal rendelkeznek, és fontos szerepük van a sejtek legkülönbözőbb folyamatainak szabályozásában. Nem egy órakomponensről kimutatták nemrégiben azt, hogy szerepet játszik a stressz-válaszok kialakításában, befolyásolja a hormonrendszer müködését, vagy éppen a metabolikus folyamatok szabályozásában vesz részt.

A laboratóriumunkban azonosított LIP1 fehérje

- az első kis GTP-áz, ami kapcsolatba hozható a cirkadián órával,

- részt vesz a fotomorfogenikus folyamatok szabályozásában,

- valamint megtalálható a sejtmagban és a citoplazmában egyaránt.

A közelmúltban végzett vizsgálatok során megállapítottuk, hogy a lip1 mutáns növények érzékenyek só stresszre, valamint hogy sziklevelük börszöveti sejtjei rendellenes morfológiát mutatnak.

Célunk annak megismerése és kiderítése volt, hogy a fent említett folyamatokban hogyan vesz részt a LIP1. Munkánk során az alábbi kérdések megválaszolásához végeztünk kísérleteket,

- mely órakomponenseken keresztül szabályozza a LIP1 a cirkadián óra működését,

- mely fotoreceptorokon keresztül vesz részt a fotomorfogenezisben,

- mi a szerepe a stressz-válaszok kialakításában,

- mi okozza a bőrszöveti sejtek morfológiájának elváltozását, továbbá hogy

- a LIP1 sejten belüli elhelyezkedésének van-e szerepe ezen funkciók ellátásában. 


\section{ANYAGOK ÉS MÓDSZEREK}

\section{Tápoldatok és táptalajok}

\section{Bakteriális táptalajok}

LB (Luria-Bertani medium): $10 \mathrm{~g} / 1$ tripton (Reanal), $5 \mathrm{~g} / 1$ élesztő kivonat (Reanal), $10 \mathrm{~g} / 1$ $\mathrm{NaCl}$ (Reanal); táptalajhoz szükség esetén: $15 \mathrm{~g} / \mathrm{l}$ agar (Reanal), kiegészítve $5 \mathrm{M} \mathrm{KOH}$-dal pH 7.0-ra

YEB (Yeast Beef, Agrobacterium táptalaj)(pH 7.0): 5g/l marhahús kivonat (Difco), 1g/1 élesztő kivonat, 5g/1 Bacto ${ }^{\circledR}$ pepton (Difco), $5 \mathrm{~g} / 1$ szaharóz (Reanal), $2 \mathrm{mM} \mathrm{MgSO}_{4}$ (csíramentesre szürve, autoklávozás után hozzáadva; Reanal); táptalajhoz szükség esetén: $15 \mathrm{~g} / 1$ Bacto $^{\circledR}$ agar (Difco)

\section{Növényi táptalajok}

- MS3 (Murashige-Skoog medium) (pH 5.6): 4.3 g/1 MS por (Murashige-Skoog sókeverék, Sigma), 3\% szaharóz, 1\% agar (Difco)

- 1/2MS1 (Murashige-Skoog Medium) (pH 5.6): 2.16 g/l MS por (Murashige-Skoog sókeverék, Sigma), 1\% szaharóz, 1\% agar (Difco)

- $\mathrm{AM}$ (Arabidopsis Medium) (pH 5.6): $2.16 \mathrm{~g} / \mathrm{l}$ MS por, 1\% szaharóz, 0.2\% phytagel (Sigma)

Munkánk során az 1. táblázatban feltüntetett antibiotikum törzsoldatokat használtuk, melyeket csíramentesre szürve a tápoldatba, ill. táptalajba autoklávozás $\left(121^{\circ} \mathrm{C}, 25\right.$ perc $)$ és $60{ }^{\circ} \mathrm{C}$-ra hütés után kevertünk. A klaforánt a baktériumfertőzés csökkentése érdekében használtuk, a Basta ${ }^{\circledR}$ pedig az AgrEvo (Bad Soden, Németország) cég által forgalmazott glufozinát hatóanyagú gyomirtószer, amit transzgenikus növények szelektálására használtunk. 


\begin{tabular}{|c|c|c|}
\hline Szervezet & Szelektáló ágens & Koncentráció \\
\hline \multirow{2}{*}{$\begin{array}{c}\text { Escherichia } \\
\text { coli }\end{array}$} & Ampicillin (Amp) & $100 \mu \mathrm{g} / \mathrm{ml}$ \\
\cline { 2 - 3 } Agrobacterium \\
\begin{tabular}{c} 
tumefaciens \\
\cline { 2 - 3 }
\end{tabular} & Kanamicin (Km) & $50 \mu \mathrm{g} / \mathrm{ml}$ \\
\cline { 2 - 3 } & Karbenicillin (Cb) & $100 \mu \mathrm{g} / \mathrm{ml}$ \\
\cline { 2 - 3 } Arabidopsis & Rifampicin (Rif) & $200 \mu \mathrm{g} / \mathrm{ml}$ \\
\cline { 2 - 3 } thaliana & Higromicin (Hyg) & $25 \mu \mathrm{g} / \mathrm{ml}$ \\
\cline { 2 - 3 } & Klaforán (Cf) & $250 \mu \mathrm{g} / \mathrm{ml}$ \\
\cline { 2 - 3 } & Basta ${ }^{\circledR}$ & $20000 \mathrm{x}$ \\
\hline
\end{tabular}

1. táblázat. A munkánk során szelektáláshoz használt ágensek

\section{Kísérleti élőlények}

Növények

Kísérleteinkhez Arabidopsis thaliana Columbia-0 és a vele nagyfokú rokonságot mutató C24 ökotípusait használtuk, valamint a 2. táblázatban összefoglalt mutáns növényvonalakat:

\begin{tabular}{|c|c|c|c|}
\hline Vonal & Hivatkozás & Mutáció típusa & Háttér \\
\hline lip 1-1 & Kevei és mtsai, 2007 & deléció & $\mathrm{C} 24$ \\
\hline lip1-2 & Kevei és mtsai, 2007 & $\begin{array}{l}\text { T-DNS } \\
\text { inszerció }\end{array}$ & Col-3 \\
\hline ccal-1 & Green és Tobin, 1999 & $\begin{array}{l}\text { T-DNS } \\
\text { inszerció }\end{array}$ & Col-0 \\
\hline gi (SALK 092757) & - & $\begin{array}{c}\text { T-DNS } \\
\text { inszerció }\end{array}$ & Col-0 \\
\hline prr5-1 & $\begin{array}{l}\text { Eriksson és mtsai, } \\
2003\end{array}$ & $\begin{array}{c}\text { T-DNS } \\
\text { inszerció }\end{array}$ & Col-0 \\
\hline prr9-1 & $\begin{array}{l}\text { Eriksson és mtsai, } \\
2003\end{array}$ & $\begin{array}{l}\text { T-DNS } \\
\text { inszerció }\end{array}$ & Col-0 \\
\hline tocl-4 & $\begin{array}{c}\text { Hazen és mtsai, } \\
2005 \mathrm{a}\end{array}$ & Q103STOP & Col-0 \\
\hline phyA-211 & Reed, 1994 & deléció & $\begin{array}{c}\text { Col- } \\
\text { pOCA107-2 }\end{array}$ \\
\hline phyB-9 & Reed, 1993 & W397STOP & Col-0 \\
\hline $\begin{array}{c}\text { cry } 1-304 \text { cry2-1 } \\
(\text { crylcry2) }\end{array}$ & $\begin{array}{c}\text { Mockler és mtsai, } \\
1999\end{array}$ & deléció & Col-0 \\
\hline
\end{tabular}

2. táblázat. A vizsgálatok során használt mutáns Arabidopsis thaliana növények 


\section{Baktériumok}

A klónozó müveletekhez az Escherichia coli XL-1 Blue törzsét használtuk (Stratagene). A növénybe juttatandó T-DNS alapú plazmidokat elöször Escherichia coli S17-1 törzsébe vittük be. Ez a konjugatív funkciókat hordozó törzs képes plazmidot átadni az Agrobacterium tumefaciens GV3101 törzsének. Utóbbi két törzs Dr. Koncz Csaba laboratóriumából származik (Max-Planck Intézet, Köln).

\section{Molekuláris biológiai és biokémiai módszerek}

\section{Plazmidok}

A növényekbe juttatandó konstrukciókat általában pBluescript ${ }^{\circledR}$ II KS/SK plazmidban (Stratagene) állítottuk össze, vagy a célplazmidban hoztuk létre. Célplazmidunk a pPCV (Plant Cloning Vector) volt, melyet Dr. Koncz Csaba csoportja fejlesztett ki. Két változatát használtuk ennek a plazmidnak, a higromicin rezisztenciáért felelős higromicinfoszfotranszferáz gént tartalmazó (pPCVH), valamint a glufozinát rezisztenciáért felelős foszfinotricin-acetiltranszferáz gént tartalmazó változatot (pPCVB). Ezek a plazmidok az Agrobacterium tumefaciens Ti-plazmidján alapulnak. Ennek jobb és bal oldali határoló szekvenciái közötti DNS szakaszt (T-DNS) az Agrobacterium képes bejuttatni növényi sejtekbe, ahol azok véletlenszerüen beépülnek a növény génállományába. A pPCV plazmid olyan elemeket is tartalmaz $\left(\mathrm{ORI}_{\mathrm{ColE} 1}\right.$ replikációs origó és az ampicillin/karbenicillin rezisztenciáért felelős $\beta$-laktamáz gén), amelyek lehetővé teszik fennmaradását Escherichia coli sejtekben.

\section{Riportergén és génkonstrukciók készítése}

A promóter aktivitás vizsgálatok elvégzéséhez a CAB2:LUC, CCR2:LUC, CCA1:LUC, LHY:LUC, PRR9:LUC, GI:LUC markergéneket használtuk. Ezeket a következő elemekből építettük fel:

- $C A B 2$ promóter - $C A B 2$ gén kódoló része előtti 320 bp-os szakasz

(Millar és mtsai, 1992)

- CCR2 promóter - a gén kódoló része előtti 2233 bp-os szakasz

(Doyle és mtsai, 2002)

- CCA1 promóter - a gén kódoló része előtti 1128 bp-os szakasz

(Doyle és mtsai, 2002) 
- LHY promóter - a gén kódoló része előtti 1812 bp-os szakasz (Kevei és mtsai, 2007a)

- GI promóter - a gén kódoló része előtti 2749 bp-os szakasz (Palágyi és mtsai, 2010)

- PRR9 promóter - a gén kódoló része elötti 1330 bp-os szakasz (Palágyi és mtsai, 2010).

A teljes hosszúságú LIP1 cDNS klónozásához a RIKEN intézettől (Yokohama) vásárolt pda02083 jelölésü cDNS klónt használtuk. A restrikciós endonukleáz emésztéseket és egyéb DNS módosító kezeléseket a forgalmazó (ThermoScientific) által szállított pufferekben és körülmények között végeztük. A termékeket agaróz gélen (SeaKem ${ }^{\circledR}$ LE, Cambrex), elektroforézissel választottuk el, a megfelelő DNS darabokat a gélből kivágtuk és fenolozással tisztítottuk. A DNS szakaszokat a T4 DNS ligázzal a forgalmazó (ThermoScientific) útmutatásai alapján kapcsoltuk össze. A ligált DNS-eket Inoue (1990) módszere szerint előkészített XL-1 Blue sejtekbe egy gyors és hatékony transzformációs módszerrel (Pope és Kent, 1996) juttattuk be. A plazmidot hordozó baktériumsejtek szelektálását a megfelelő antibiotikumot tartalmazó LB lemezeken $37{ }^{\circ} \mathrm{C}$-on, 16 órán át végeztük. A plazmidokat az Escherichia coli sejtekből a hagyományos lúgos feltárás módosított változatával tisztítottuk (Ahn és mtsai, 2000), majd felépítésüket restrikciós enzimekkel ellenőriztük. A lip1-2 mutáció komplementálásához a 35S:YFP-LIP1, 35S:YFP-LIP1-NES és 35S:YFP-LIP1-NLS konstrukciókat készítettük el. A 35S:YFP-LIPl esetében a laboratóriumunkban már elkészített konstrukciót használtuk (Kevei és mtsai, 2007a). Az SV40 NLS és a PKI (protein kináz inhibítor) NES elemeket tartalmazó konstrukciók elkészítéséhez az elemeket és a dohánymozaik vírus $35 \mathrm{~S}$ promoterét, illetve az YFP stop kodon nélküli változatát már tartalmazó, szintén laboratóriumunkban előállított pPCV alapú konstrukciókat használtuk fel (Palágyi és mtsai, 2010).

\section{Növényi DNS tisztítása}

Körülbelül $1 \mathrm{~cm}^{2}$ felületü levél mintát folyékony nitrogénben lefagyasztottunk, majd 1.5 ml-es centrifugacsőben elporítottunk. A mintára $500 \mu \mathrm{l}$ CTAB (cetil-trimetil-ammónium bromid) puffert (1\% CTAB, $100 \mathrm{mM}$ Tris $\cdot \mathrm{HCl}$ pH 8.0, $20 \mathrm{mM}$ EDTA, $1.42 \mathrm{M} \mathrm{NaCl,} \mathrm{1 \%} \mathrm{PVP}$ 40 (polivinil-pirrolidon 40), 0.5\% $\beta$-merkaptoetanol) mértünk, majd többször összerázva a csövet, 30 percig $65^{\circ} \mathrm{C}$-on inkubáltuk. 10 perc centrifugálás után (szobahőmérséklet, 10000g) a tiszta felülúszót új csőbe mértük át, és azonos térfogatú kloroformmal ráztuk össze. A vizes és a szerves fázist 10 perc centrifugálással választottuk szét. A felső vizes fázisból a DNS-t 
0.75x térfogatnyi 2-propanollal csaptuk ki szobahőmérsékleten 10 perc alatt, majd 10 perc centrifugálással ülepítettük. A csapadékot 70\%-os etanollal mostuk, légszivattyúval szárítottuk és $100 \mu \mathrm{l}$ desztillált vízben feloldottuk. A mintát $10 \mu \mathrm{g}$ RNáz-A enzimmel kezeltük $37{ }^{\circ} \mathrm{C}$-on 1 órán át, majd fenol-kloroform (1:1) elegyével extraháltuk. Centrifugálás után a vizes fázist kloroformmal is tisztítottuk, majd a vizes fázisból a DNS-t 0.2 térfogatnyi $3 \mathrm{M}$ nátrium-acetát ( $\mathrm{pH}$ 5.2) és 0.75 térfogatnyi 2-propanol hozzáadásával szobahőmérsékleten 10 perc alatt csaptuk ki. Centrifugálás és 70\%-os etanollal történő mosás után a csapadékot megszárítottuk és $100 \mu \mathrm{l}$ desztillált vízben oldottuk fel.

\section{Növényi RNS tisztítása}

Össz-RNS-t $\sim 100 \mathrm{mg}$, folyékony nitrogénben porított növényi anyagból a Qiagen RNeasy ${ }^{\circledR}$ Plant Mini Kit-jével tisztítottunk (oszlopon történő RNáz-mentes DNáz kezeléssel kiegészítve) a gyártó leírása alapján. A kapott RNS mennyiségét és minőségét a minta 260 és 280 nm-en mért fényelnyeléséből határoztuk meg.

\section{mRNS szint meghatározása valós idejü PCR-rel}

Mérési pontonként $\sim 100 \mathrm{db}$ csíranövényböl tisztítottunk össz-RNS-t. $1 \mu \mathrm{g}$ RNS-ből cDNS-t a ThermoScientific által gyártott RevertAid ${ }^{\mathrm{TM}}$ First-Strand cDNA Synthesis Kit segítségével készítettünk a gyártó útmutatásának megfelelően. A méréseket valós idejü PCRrel ABI PRISM ${ }^{\circledR} 7300$ (Applied Biosystems) gépen, ABI Power SYBR ${ }^{\circledR}$ Green PCR Master Mix (Applied Biosystems) használatával végeztük.

Minden primerpár esetében kalibrációs egyenest készítettünk, és az egyes mintákban az mRNS szintet ennek segítségével határoztuk meg (Standard Curve Method, a PCR készülék gyártójának útmutatása alapján). A kapott értékeket a minták $\beta$-TUBULIN 2 és $\beta-T U B U L I N 3$ mRNS szintjére vonatkoztattuk, a dolgozatban a továbbiakban TUBULIN-ként feltüntetve. Minden mintán három párhuzamos mérést végeztünk. A használt primerek az alábbiak voltak:

CCA1 RT-PCR F: 5'-CTGTGTCTGACGAGGGTCGAA-3'

CCA1 RT-PCR R: 5'-ATATGTAAAACTTTGCGGCAATACCT-3'

GI RT-PCR F: $\quad$ 5'-AATTCAGCACGCGCCTATTG -3'

GI RT-PCR R: $\quad$ 5'-GTTGCTTCTGCTGCAGGAACTT -3'

PRR9 RT-PCR F: 5'- GCCTTCTCAAGATTTGAGGAAAGC -3'

PRR9 RT-PCR R: 5'- TTTGGCTCACCTGAAGTACTCTC -3'

TOC1 RT-PCR F: 5'-ATCTTCGCAGAATCCCTGTGATA-3'

TOC1 RT-PCR R: 5'-GCACCTAGCTTCAAGCACTTTACA-3'

RD29A RT-PCR F: 5'- ATCCCACCAAAGAAGAAACTG -3' 
RD29A RT-PCR R: 5' - TCAGGAGACTCATCAGTCAC -3'

RD29B RT-PCR F: 5'- GATGAGTATGACGAGCAAGAC -3'

RD29B RT-PCR R: 5'- GACTTAGGTTTACCCGTTACAC -3'

SOS2 RT-PCR F: 5'- TACACGAAACTTCAAGACAAGG -3'

SOS2 RT-PCR R: 5'- CCACCTCGTAAATCTCTATCAC -3'

RAB18 RT-PCR F: 5'- GCTTAAGACAAGAAGAACATGG -3'

RAB18 RT-PCR R: 5' - ATTTCCGTACTCGTCATACTG -3'

DEL1 RT-PCR F: 5'- TGTCTTGTCGTCAATGAATCTC -3'

DEL1 RT-PCR R: 5'- CTCACCATTGTACCCTAACC -3'

TUB2/3 RT-PCR F: 5'- CCAGCTTTGGTGATTTGAAC -3'

TUB2/3 RT-PCR R:5' - CAAGCTTTCGGAGGTCAGAG -3'

A PCR körülményei az alábbiak voltak: $94{ }^{\circ} \mathrm{C} 2.5$ perc, 40 ciklus $\left(95{ }^{\circ} \mathrm{C} 15 \mathrm{mp}, 60{ }^{\circ} \mathrm{C} 1\right.$ perc), $95^{\circ} \mathrm{C} 15 \mathrm{mp}, 60^{\circ} \mathrm{C} 15 \mathrm{mp}$.

\section{Növényi összfehérje tisztítása}

50-100 mg növényi anyagot folyékony nitrogénben lefagyasztottunk és 1.5 ml-es csőben porrá őröltük. Az elporított mintára 100 mg-onként $200 \mu \mathrm{l} 95{ }^{\circ} \mathrm{C}$-ra elömelegített feltárópuffert mértünk (4 M urea, 5\% SDS, 5\% $\beta$-merkaptoetanol, 16.66\% glicerin). A mintákat homogenizáltuk, majd $95{ }^{\circ} \mathrm{C}$-os vízfürdőbe helyeztük öket 10 percre. Többször összeráztuk a csöveket. A törmeléket ezután 30 perc szobahőmérsékletű centrifugálással távolítottuk el. A tiszta felülúszót új csövekbe mértük át. Az így elkészített mintákat vittük fel SDS poliakrilamid gélre.

\section{Relatív fehérjemennyiségek meghatározása immunoblot módszerrel}

Mintánként $20 \mu \mathrm{g}$ fehérjekivonatot analizáltunk 10\%-os SDS-poliakrilamid gélen Tris/glicin/SDS futattópufferben. A gélből az elválasztott fehérjéket elektroblot készülékkel (Bio-Rad; $100 \mathrm{~V}, 2 \mathrm{~h}$ ) átvittük Immobilon ${ }^{\circledR} \mathrm{P}$ PVDF (polivinilidén-difluorid) műanyag membránra (Millipore). Az átvitel után a membránt TBST pufferrel $(20 \mathrm{mM}$ Tris $\cdot \mathrm{HCl} \mathrm{pH} 7.5$, $150 \mathrm{mM} \mathrm{NaCl}, 0.05 \%$ Tween $^{\circledR} 20$ ) öblítettük át. A szabadon maradt kötőhelyeket 5\% sovány tejporral kiegészített TBST pufferben semlegesítettük $4{ }^{\circ} \mathrm{C}$-on egy éjszakán át. Ezután a membránt YFP elleni elsődleges ellenanyaggal kezeltük (Clontech, Living Colors A.v. Monoclonal Antibody JL-8, 500-szoros hígításban TBST pufferben). Az ellenanyagot egy órán keresztül hagytuk a membránon, majd 3×10 perc TBST pufferes mosással távolítottuk el az ellenanyag maradványokat. Ezután TBST pufferben 10.000-szeresre hígított, alkalikusfoszfatázhoz kapcsolt egér-IgG elleni másodlagos ellenanyaggal (Sigma, A-3562) kezeltük a 
membránt szobahőmérsékleten egy óráig. Ezt követően $3 \times 10$ percig TBST pufferben mostuk. A folyadék eltávolítása után $100 \mathrm{mM}$ Tris $\mathrm{HCl} \mathrm{pH}$ 9.7, $100 \mathrm{mM} \mathrm{NaCl}, 50 \mathrm{mM} \mathrm{MgCl} 2,0.02 \%$ BCIP (5-bróm-4-klór-3-indolil foszfát), 0.03\% NBT (nitroblue-tetrazólium) összetételü, szobahőmérsékletű előhívó oldatba helyeztük a membránt,és addig hagytuk benne, amíg a fehérje sávok láthatóvá nem váltak. A reakciót vizes öblítéssel leállítottuk, majd a membránt megszárítottuk és képet készítettünk róla.

\section{Növények előkészítése és nevelése, alkalmazott vizsgálatok}

\section{Magsterilezés, növénynevelés}

Az Arabidopsis thaliana magokat legalább három napig desztillált vízben $4{ }^{\circ} \mathrm{C}$-on sötétben hidegkezeltük, majd felszínüket 10 percig $0.5-1 \%$-os nátrium hipoklorit oldatban sterilizáltuk. Ezután csíramentes desztillált vízzel ötször átmostuk. Az így kezelt magokat szelekcióhoz AM, lumineszcencia mérésekhez, stresszvizsgálatokhoz és só indukált gének RNS szintü vizsgálatához MS3, endoreduplikáció és sejtalak vizsgálatokhoz pedig 1/2MS1 lemezekre szélesztettük. A növényeket $22^{\circ} \mathrm{C}$-on, 12 óra sötét/12 óra fehér fény (50 $\mu \mathrm{mol}$ foton $\mathrm{m}^{-2} \mathrm{~s}^{-1}$ ) cikluson neveltük növénynevelő kamrában (MLR-350, Sanyo) hét napig (a továbbiakban 12:12 LD kezelésként feltüntetve, az angol light és dark megjelölések rövidítéseként). Az ettől eltérő nevelési körülmények a dolgozatban külön jelölve vannak. A szik alatti szár megnyúlásának vizsgálatához a növényvonalak magjait nedves szürőpapírra szélesztettük, három napig $4{ }^{\circ} \mathrm{C}$-on sötétben hidegkezeltük. Majd $22{ }^{\circ} \mathrm{C}$-on $50 \mu \mathrm{mol}$ foton $\mathrm{m}^{-2}$ $\mathrm{s}^{-1}$ fehér fénnyel négy órán keresztül indukáltuk a csírázást, ezután 20 óra $22{ }^{\circ} \mathrm{C}$ sötét kezelést alkalmaztunk, majd a megfelelő monokromatikus fényforrás alá helyeztük őket a kívánt fényintenzitáson. A növényeket ezután agar lemezre fektettük és a szik alatti szár hosszát az ImageJ program segítségével mértük.

A stressz vizsgálatokhoz a csíranövényeket 12:12 LD cikluson 14 napig só, illetve ozmotikum tartalmú táptalajon neveltük. A só csírázásra gyakorolt hatását $200 \mathrm{mM} \mathrm{NaCl}$ tartalmú MS3 lemezen vizsgáltuk. A csírázó magokat naponta számoltuk öt napig. Csírázó magnak azt a magot tekintettük, amelynek a gyököcskéje megjelent. Sötétben és 12:12 LD cikluson nevelt növényeket vizsgáltunk. A sötétben tartott minták esetében a csírázást naponta új lemezen számoltuk. A gyökérhossz méréshez a növényeket 12:12 LD cikluson neveltük hét napig sómentes MS3 táptalajon, majd különböző koncentrációjú NaCl-ot tartalmazó, függőleges helyzetü lemezre helyeztük át őket. A gyökér hosszát az ImageJ program segítségével mértük, az értékeket sómentes talajon nevelt növények gyökérhosszára normalizáltuk. 
Az ABA csírázásra gyakorolt hatását 0.3 és $0.5 \mu \mathrm{M}$ ABA tartalmú MS3 lemezen vizsgáltuk. A lemezeket 12:12 LD ciklusra vagy folyamatos sötétbe helyeztük. A csírázó magokat naponta számoltuk öt napig.

\section{Transzgenikus növények előállítása}

A növényekbe juttatni kívánt pPCV alapú plazmidot először Escherichia coli S17-1 törzsbe vittük be, amely képes konjugációra a növényi transzformáció során használt Agrobacterium tumefaciens GV3101 PMP90RK háromszoros rezisztenciát hordozó törzsével. A két baktériumtenyészetből folyadékkultúrát neveltünk, 0.5-0.5 ml-t összekevertünk, a sejteket ülepítettük, majd a tömény baktérium keveréket YEB táplemezen növesztettük. A 24 óra után a növekedésnek indult baktériumtenyészetből kis mennyiséget rifampicin, karbenicillin és kanamicin tartalmú YEB lemezre szélesztettünk. A felnövekvő Agrobacterium telepeket legalább három alkalommal passzáltuk, hogy az E. colitól megtisztítsuk, mielőtt a növények kezeléséhez használtuk volna őket.

Az Agrobacterium által hordozott konstrukció növényekbe juttatásához Arabidopsis növények virágzatát mártogattunk bele folyadékkultúrában nevelt baktériumok 3\%-os szachazózban felszuszpendált oldatába (Clough és Bent, 1998). A felnevelt növényekről magot gyüjtöttünk. Megfelelő szelektív ágensekkel kiegészített AM táptalajon csíramentes körülmények között válogattuk ki a rezisztens egyedeket. Ezeket kellően erőteljes gyökérzet kialakulása után (10-12 nap) földbe ültettük és felneveltük üvegházi körülmények között. Általában 20-30 független T1 vonalat állítottunk elő. Vizsgálatainkat a T3 nemzedék homozigóta egyedein végeztük.

\section{Fénykezelések}

A fénykezelésekhez Quantum Devices Inc. (USA) Snaplite ${ }^{\mathrm{TM}}$ LED-eket tartalmazó monokromatikus fényforrásokat használtuk. Az alkalmazott vörös fény hullámhossza $665 \pm 15$ nm, a távoli-vörös fény hullámhossza $730 \pm 15 \mathrm{~nm}$, a kék fény hullámhossza pedig $470 \pm 15 \mathrm{~nm}$ volt. A használt fényintenzitást a kísérletek leírásánál külön tüntettük fel.

\section{Lumineszcencia-mérés élö növényben}

A luciferázos markergéneket kifejező csíranövényeket 12:12 LD cikluson állandó $22{ }^{\circ} \mathrm{C}$ on hét napig neveltük MS3 lemezeken. A mérés kezdete előtt 6-8 órával a csíranövényeket steril körülmények között 96 zsebes mikrotiterlemezbe helyeztük, melynek minden zsebe 0.25 ml MS3 táptalajt tartalmazott. Minden egyes növényre $20 \mu \mathrm{l} 2.5 \mathrm{mM}$-os luciferin (DLuciferin Firefly, Biosynth $\mathrm{AG}$ ) oldatot cseppentettünk. A mérés a csírázást követő hetedik 
napon indult. A méréseket TopCount ${ }^{\circledR} \mathrm{NXT}^{\mathrm{TM}}$ önmüködő luminométerrel (PerkinElmer) végeztük, amely a lemez zsebeiben elhelyezett csíranövény által kibocsátott fényt a mérési idő végéig folyamatosan rögzítette (Hall és Brown, 2007). A luminométerben a mintákat az egyes kísérleteknél külön leírt fényviszonyok között tartottuk. A folyamatos fényben levő minták csak a mérés idejére (1-2 óránként 3 percre) kerültek a mérőtérben sötétbe, ami a cirkadián óra müködését nem befolyásolta (Millar és mtsai, 1995). A mérési eredmények feldolgozása a TopTempII nevü Microsoft Excel makróval (Dr. Andrew Millar fejlesztése) történt. A luminométer által mért értékek az egy másodperc alatt beérkezett fotonok számát (count per seconds, cps) mutatják. Az egyedi növények esetében mért értékeket az adott növény összes mért értékének átlagával osztottuk el. Ezt az értéket az idő függvényében ábrázoltuk. Az ábrákon legalább 16 csíranövény lumineszcencia értékéből számolt átlagértéket tüntettük fel. A periódushossz mérését a Biological Rhythms Analysis Software System (BRASS) (Locke és mtsai, 2005) segítségével végeztük el. Ezzel a Microsoft Excel alapú makróval a TopCount ${ }^{\circledR} \mathrm{NXT}^{\mathrm{TM}}$ luminométerrel mért adatok kiértékelhetőek. A program a „Fast Fourier Transform-Non-Linear Least Squares (FFT-NLLS)” módszerrel (Plautz és mtsai, 1997) minden egyedi növény adatsorára illesztett görbe alapján ad becslést a periódusra. Minden kísérletben 80-120 órás mérési időtartamból származó adatokat használtunk fel. Csoportonként legalább 20 növény periódusát mértük. A periódus becslése során csak azokat az értékeket vettük figyelembe, amelyek a 20 és 28 óra közti cirkadián tartományba estek. A hibahatárokat a standard hiba (Standard Error, SE) középértékeként $( \pm \mathrm{SEM})$ tüntettük fel minden esetben.

\section{Alkalmazott mikroszkópos eljárások}

\section{Epifluoreszcens mikroszkópia}

Az epifluoreszcens vizsgálatokat Axioskop Zeiss mikroszkóppal végeztük, Axiocam Zeiss kamerarendszerrel kombinálva. Az YFP nyomonkövetéséhez YFP-szürőkészletet használtunk (AHF Analysentechnik).

\section{Pásztázó elektronmikroszkópia (SEM)}

A pásztázó elektronmikroszkópos képek Zeiss Supra 40VP (Carl Zeiss SMT AG) hidegkatódos Emitech K1250X (Quorum Emitech) transzfer rendszerrel kombinált készülékkel készültek. A biológiai mintákat kriogenizációs eljárással készítettük elő, a friss növényi szövetet Tissue-Tec (O.C.T. Compound) ragasztóval rögzítettük a mintatartó asztalhoz és arany/palládium réteggel vontuk be vezetőrétegként. 


\section{Differenciál interferencia kontraszt (DIC) mikroszkópia és a sejtalak faktor számítása}

A vizsgálandó növényi mintát 12 órán át áztattunk 160 g klór-hidrát (Sigma-Aldrich) 100 $\mathrm{ml}$ vízzel és $50 \mathrm{ml}$ glicerinnel készített oldatában. DIC optikával (Leica) felszerelt Leica DMRB mikroszkóppal vizsgáltuk az így előkészített szikleveleket. A képeket Leica DFC 490 kamerával készítettük a Leica Application Suite 2.5.0 szoftvert használva. A bőrszöveti sejtek kerületét és területét az ImageJ program segítségével mértük meg, és a sejtalak faktort $4 \pi$ terület/kerület ${ }^{2}$ formájában adtuk meg. A szignifikanciát t-teszt alapján a SigmaStat 3.5 szoftver segítségével határoztuk meg.

\section{Konfokális lézer pásztázó mikroszkópia}

A csíranövények festetlen szikleveleit vizsgáltuk. Az YFP fluoreszcens jelét 40× és $63 \times$ lencsékkel, valamint argon/kripton lézerrel és $405 \mathrm{~nm}$ dióda lézerrel (Leica) felszerelt Leica TCS SP2 AOBS CLSM mikroszkóppal detektáltuk.

\section{DNS tartalom meghatározása áramlási citometriával}

A vizsgálandó növényi anyagot homogenizáltuk, CyStain UV precise P DNA festékkel (Partec) festettük. $50 \mu \mathrm{m}$ átméröjü filter segítségével távolítottuk el a törmeléket. A ploidia szintet Ploidy Analyser PA-1 (Partec) segítségével mértük és FloMax 2.52 szoftverrel (Partec) értékeltük az eredményeket.

\section{Statisztikai analízis}

A szignifikanciát Student-féle t-teszttel vizsgáltuk, illetve ahol páronkénti összehasonlítás volt szükséges több adatsor esetén (ploidia és szik alatti szár mérések lip1 mutációval kombinált fotoreceptor mutánsokban), ott Tukey-féle eljárás és egyutas ANOVA módszerekkel a SigmaStat 3.5 szoftver segítségével határoztuk meg, hogy a tapasztalt különbség szignifikáns-e. A P-érték jelöli ki azt a szignifikancia-tartományt, amelyen belül már biztosan nincs szignifikáns különbség az összehasonlított adatsorok között. Ha a P-érték nagy, akkor a két mintasor között nincs szignifikáns különbség $(\mathrm{P}<0.05)$, míg ha kicsi, akkor biztosan szignifikánsan különböznek $(\mathrm{P}<0.001)$.A dolgozatban használt jelölések: *** $\mathrm{P}$ $<0.001, * * \mathrm{P}<0.01$, és $* \mathrm{P}<0.05$. 


\section{EREDMÉNYEK}

\section{A LIP1 fehérje hiányában megváltozik a sziklevél felszíni bőrszöveti sejtjeinek alakja}

A lip1-1 és lip1-2 mutáns csíranövények mikroszkópos analízise azt mutatta, hogy a mutáció a sziklevelek felszíni bőrszöveti sejtejeinek rendellenes fejlődését okozza. A növényeket 12:12 LD körülmények között neveltük 7 napig, majd a C24 és a lip1-1, valamint a Col-0 és a lip1-2 csíranövények sziklevelének epidermisz sejtjeit mikroszkóppal vizsgáltuk. A fényen nevelt lip1-1 és lip1-2 mutáns csíranövények bőrszöveti sejtjeinek alakja jellegzetes módon eltér a vad típusétól (8. ábra A), mivel nem alakul ki a vad típusra jellemző, karéjos sejtalak. Azonban az etiolált növények esetében különbség nem figyelhető meg (8. ábra F). A fényen nőtt lip 1-1 és lip1-2 mutánsok bőrszöveti sejtjei kisebbek, mint a vad típusé. A sejtalak lekerekítettebb, a sejtek alakja kevésbé összetett. A sejt alak faktor ami a sejtek gömbölyüségének mértékét adja meg, szignifikáns különbséget mutat t-teszt alapján a vad típus és a lipl mutánsok sejtalakja között (8. ábra B).

C24 és lip1-1, valamint Col-0 és lip1-2 növényeket 12:12 LD cikluson neveltük 7 napig majd a csíranövények sziklevelét pásztázó elektronmikroszkóppal vizsgáltuk. A lip1-2 mutánsok esetében azt tapasztaltuk, hogy a sziklevelek széle jellegzetesen felfelé görbül (8. ábra C). Ezt a morfológiai változást az okozza, hogy az epidermális sejtek nem hoznak létre összefüggő réteget a levél felszínén. Ez az elváltozás vad típusú növények esetében nem figyelhető meg. A jelenséget feltehetően egyes bőrszöveti sejtek elhalása okozza, az elhalt gázcserenyílások zárósejtjeinek és az elhalt bőrszöveti sejteknek a helye is tisztán kivehető a készített felvételeken (8. ábra D).

A lip 1-2 mutánssal ellentétben a lip1-1 esetében összefüggő bőrszöveti réteg figyelhető meg (8. ábra C), ami ökotípusok közötti eltérésre utal, tekintve hogy mindkét allél funkcióvesztéses mutáció. Továbbá, adataink azt mutatják, hogy a sejtalak megváltozása és a nem összefüggő bőrszöveti sejtréteg a fejlődés bizonyos szakaszában alakul ki, mivel lip1-1 és lip 1-2 mutáns növények első igazi levelein ezek az elváltozások nem láthatóak (8. ábra E). A növényeket ennek vizsgálatához 12:12 LD cikluson neveltük 21 napig, majd a Col-0 és a lip1-2 csíranövények sziklevelének epidermisz sejtjeit mikroszkóppal vizsgáltuk. A karéjos sejtek egyértelmüen kivehetőek voltak a lip1-2 mutánsok esetében is. Ezek a megfigyelések arra utalnak, hogy a LIP1 fehérjének fontos szerepe van a növényi életciklus korai szakaszában. 
A

Col

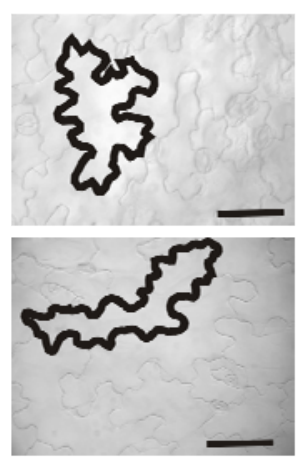

C24

C

Col
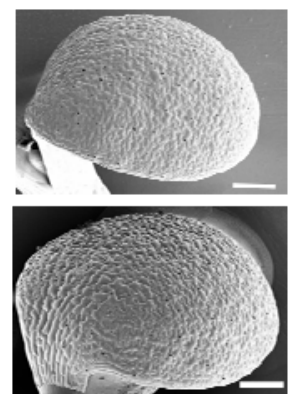

C24 lip1-2

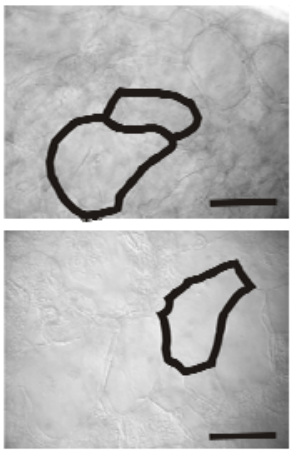

lip 1-1

lip1-2
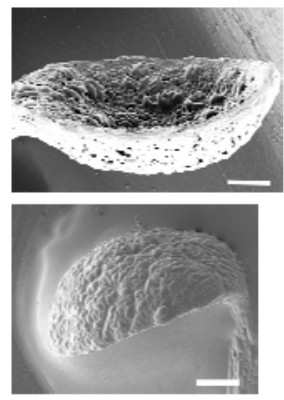

lip1-1
E

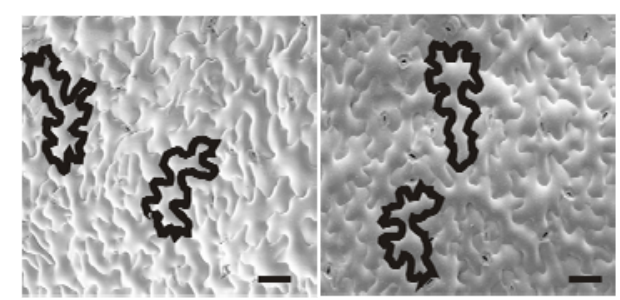

Col

lip 1-2

F

B

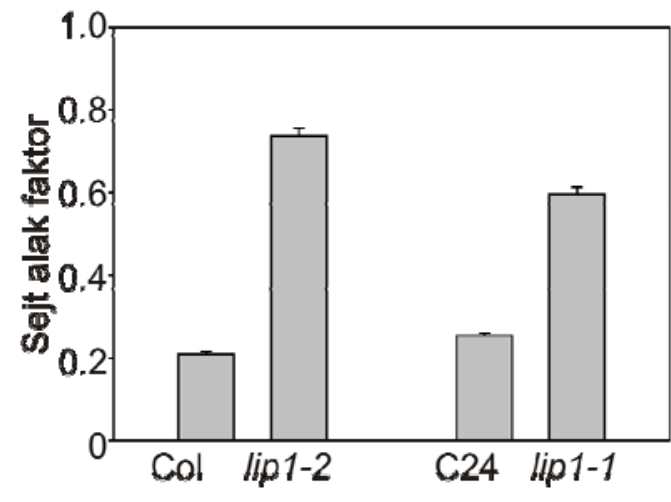

D

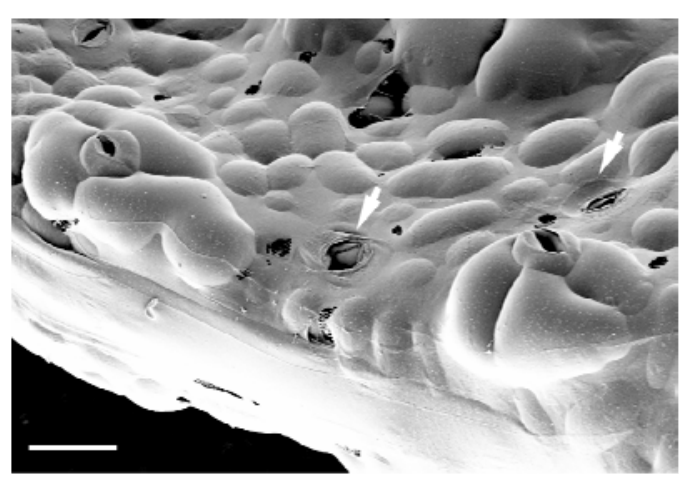

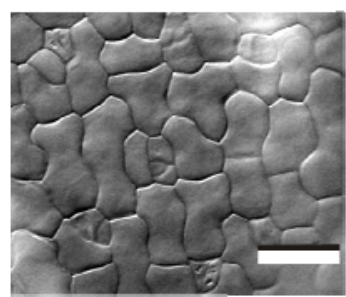

C24

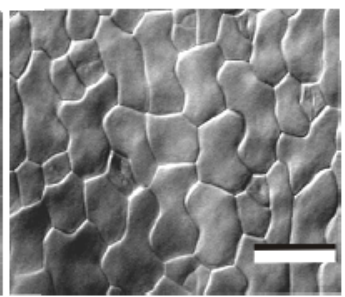

lip 1-1

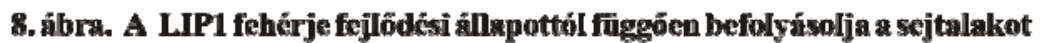

A vizsgálatokhoz a nōvényeket 12:12 LD cikluson neveltük 7(A, B, C, D) illetve 21 napig (E).

(A) Epidermisz sejtek alakja fenymikroszkóppal vizasálva, Col-0, lipl-2, C24 és lipl-1 növények sziklevelében. Skála: $50 \mu \mathrm{m}$.

(B) Sejt alak faktor a sziklevél epidermális sejtjeinek területébōl és kerületébōl számolva. 43-54 sejtet mértūnk vonalankẻnt, t-teszt: $\mathrm{P}<0.001$ minden mintảra. A hibahatárok a standard hibát jelölik (SE).

(C) SEM képek Col-0, lipl-2, C24 és lipI-1 nōvények szikleveléról. Skảla: 200 um.

(D) Közeli SEMkép lippl-2 levél fékzinérơl. Anyilakaz elhalt sztóma záróssejtekre mutatnak. Skála: $20 \mu \mathrm{m}$.

(E) SEM kćpck Col-0 ćs lipl-2 nōyényck clsơ igazi lcvelénck félkzinćrôl. Skála: 50 um.

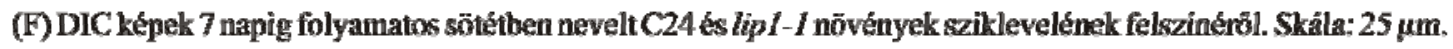




\section{A lip1 mutáns növényekben megnő a magi DNS mennyisége}

\section{A LIP1 fehérje hatása a csíranövények kromatintartalmára}

Mivel a sejtalak változása gyakran összefüggésbe hozható az örökítő anyag mennyiségének megváltozásával (Guimil és Dunand, 2007), meghatároztuk a magi DNS mennyiségét lip1 mutáns növények sziklevelében áramlási citometriával. A növényeket 12:12 LD cikluson neveltük 7 napig a mérést megelőzően. Azt tapasztaltuk, hogy a mutánsokban megnőtt az olyan sejtmagok százalékos aránya, amelyek emelkedett mennyiségü DNS-t tartalmaztak. Különösképpen megnőtt a 16-szoros kromoszómakészlettel (16C) rendelkező sejtmagok aránya, valamint a vad típussal ellentétben a lip1-2 mutánsok sziklevelében 32szeres kromoszómakészlettel (32C) rendelkező magok is detektálhatóak voltak (9. ábra A és B).
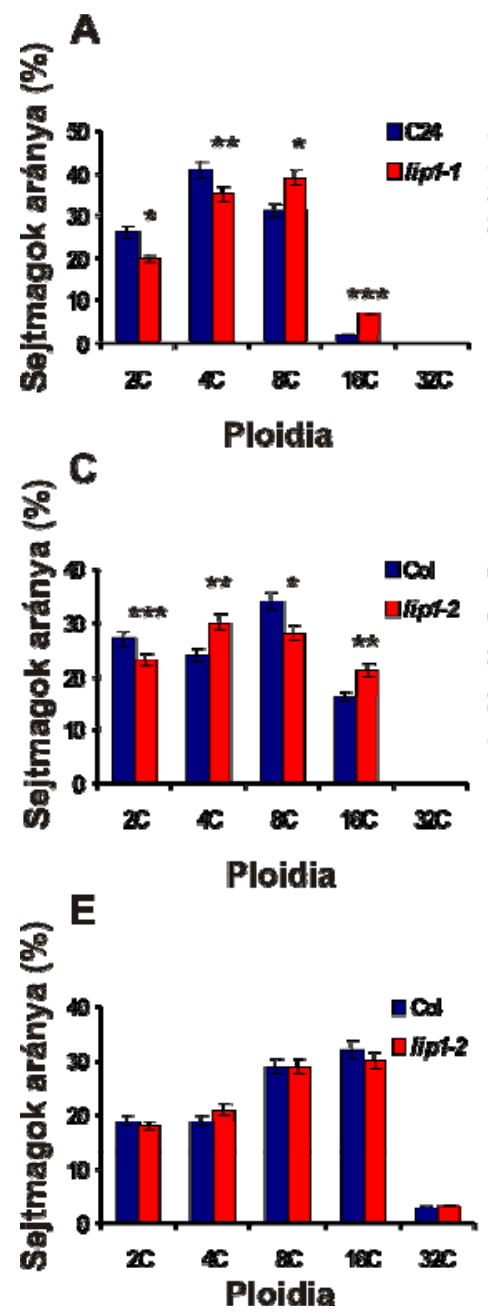

\section{$\mathbf{B}$}

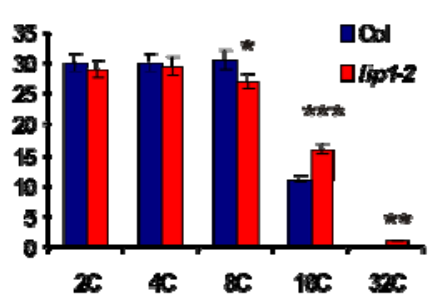

Ploldla
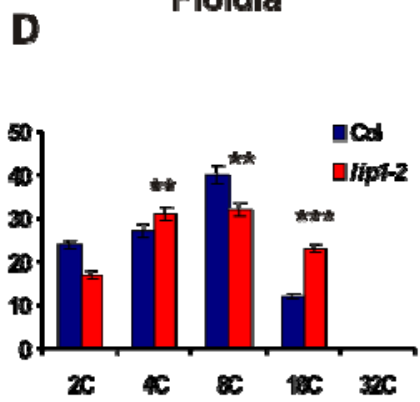

Ploidia

9. åbra. A tịp 1 mutánsokban megnổ a magi örōkítăanyag mennyisége A ploidia szintet vad típusú és lipl mutáns növényck kūlönbōzō szerveiben mértūk. A nôvényeket 12:12 LD cikluson neveltük 7 (A, B, C, D) illetve 21 (E) napig. Vizsgáltuk a szilklevelet (A, B), szárat (C), teljess nōvênyt (D) és az elsō igazi levelet (E).

A feltūntetett DNS mennyiséget tartalmazó sejtmagok százalekkos arányắt tüntettiük fél. Mérésenként 4 párhuzamos mintát vizsgaltunk. Egy minta $10 \mathrm{db}$ sziklevelet (A, B), 10 db szik alatti szárat (C), 5 db csiranövényt (D) vagy $4 \mathrm{db}$ levelct (E) tartalmazott.

A hibahatárok standand eltérés (SD) formájában vannak feltüntetve.

A ploidia szint változása gyakran jár együtt megváltozott sejtszámmal is (Sabelli és Larkins, 2009). A sejtszám változását vizsgáltuk lip1-1 mutáns és vad típusú növények sziklevelének bőrszöveti, valamint mezofill sejtjeire vonatkozóan fény/sötét cikluson nevelt (3. táblázat) és etiolált (4. táblázat) növényekben is. 


\begin{tabular}{|c|c|c|c|c|c|}
\hline \multirow[b]{2}{*}{ Genotipus } & \multirow[b]{2}{*}{$\begin{array}{c}\text { Szilkkvel méret } \\
\left(\mathrm{mm}^{2}\right)\end{array}$} & \multicolumn{2}{|c|}{$\begin{array}{l}\text { Sziklevél fekzími bōrszōveti } \\
\text { sejtck }\end{array}$} & \multicolumn{2}{|c|}{ Oszlopos parenhima } \\
\hline & & $\begin{array}{l}\text { Számiszikkevél } \\
\text { fekzzín }\end{array}$ & Méret $\left(\mu \mathrm{m}^{2}\right)$ & Szám/sziklkvêl & Méret $\left(\mu \mathrm{m}^{2}\right)$ \\
\hline $\mathrm{C24}$ & $\begin{array}{l}2.082 \pm 0.176 \\
1.568 \pm 0.194\end{array}$ & $\begin{array}{l}561 \pm 61 \\
528 \pm 77\end{array}$ & $\begin{array}{l}3697 \pm 202 \\
2874 \pm 175\end{array}$ & $\begin{array}{l}1797 \pm 253 \\
1894 \pm 310\end{array}$ & $\begin{array}{c}1165 \pm 156 \\
821 \pm 129\end{array}$ \\
\hline$P$ & $<0.001$ & 0.53 & $<0.001$ & 0.29 & 0.0041 \\
\hline
\end{tabular}

3. táblázat. Szikelevelek bôrszòveti és oszlopos parenchima sejtjeinek fỏbb jellemzôi fény/sôtét cikluson nevelt csíranövênyekben

12:12 LD cikluson7 napig nevelt növények sziklevelének felszinérōl készítettūnk digitảlis képeket. A sziklevelek (10-15 db mérésenként) és a sejtek méretét (16-22 sziklevelenként) vizsgáltuk. A mérések átlagát tūntettük fel, a hibahatárokat standard eltérés (SD) formájában adtuk meg.

\begin{tabular}{|c|c|c|c|c|c|}
\hline \multirow[b]{2}{*}{ Genotípus } & \multirow[b]{2}{*}{$\begin{array}{c}\text { Szikkevíl méret } \\
\left(\mathrm{mm}^{2}\right)\end{array}$} & \multicolumn{2}{|c|}{$\begin{array}{c}\text { Sziklevél fekzzini bōrszôveti } \\
\text { sejtek }\end{array}$} & \multicolumn{2}{|c|}{ Oszlopos parenhima } \\
\hline & & $\begin{array}{l}\text { Szán/sziklevél } \\
\text { feksin }\end{array}$ & Méret $\left(\mu \mathrm{m}^{2}\right)$ & Számiszikkevêl & Méret $\left(\mu \mathrm{m}^{2}\right)$ \\
\hline $\begin{array}{c}\mathrm{C} 24 \\
\text { lipl-1 }\end{array}$ & $\begin{array}{l}0.229 \pm 0.039 \\
0.207 \pm 0.031\end{array}$ & $\begin{array}{l}581 \pm 75 \\
549 \pm 83\end{array}$ & $\begin{array}{l}394 \pm 61 \\
368 \pm 69\end{array}$ & $\begin{array}{l}1423 \pm 281 \\
1321 \pm 235\end{array}$ & $\begin{array}{l}161 \pm 31 \\
136 \pm 27\end{array}$ \\
\hline$P$ & 0.09 & 0.47 & 0.39 & 0.18 & 0.12 \\
\hline
\end{tabular}

4. tảhlázat. SzikeIevelek hôrszồveti és oszlopos parenchima sejtjeinek fôbh jellemzôi etiolâit cxíranōvényekben

7 napig sötétben nevelt növények sziklevelének fêlszinérōl készítethünk digitális képeket. A sziklevelek (9-11 db mérésenként) és a sejtek méretét (35-60 db szilklevelenként) vizsgáltuk. A mérések ảtlagát tūntettük fel, a hỉbahatảrokat standard eltérés (SD) formájában ađtukmeg.

Érdekes módon a lip1-1 mutáns növények esetében tapasztalható megnövekedett örökítőanyag tartalom a sejtméret csökkenésével járt együtt, azonban az össz sejtszámra nem volt hatással. Következésképpen a lip1-1 mutáns növények sziklevelének mérete kisebb, mint a vad típusé. Hogy ellenőrizzük a lip1 mutáció okozta megnövekedett örökítőanyag tartalom szövetspecifikus mivoltát, szik alatti szár és teljes növény tartalmú mintákat is megvizsgáltunk az örökítőanyag mennyiségét tekintve (9. ábra C és D). A ploidia szint ezekben a mintákban nagyon hasonlított a sziklevél esetében mért szintre, ami arra utal, hogy a LIP1 által a DNS tartalomban kozott változás nem szövetspecifikus. Az első igazi levelek esetében pedig nem tapasztaltunk különbséget a ploidia szintekben lip1-2 mutáns és vad típusú növények között (9. ábra E), ami arra utal, hogy a LIP1 fejlődési stádiumtól-függő módon játszik szerepet a ploidia szint befolyásolásában.

\section{A LIP1 fényfüggő módon gátolja az endoreduplikációt}

A sejt DNS tartalma az endoreduplikáció során megnő. Sötétben nevelt Arabidopsis csíranövények szik alatti szárában négy endoreduplikációs ciklus játszódhat le, ami 32-szeres kromoszómakészletet eredményez (32C). A negyedik ciklus fény által gátolt (Gendreau és 
mtsai, 1998). Mivel a LIP1 szerepet játszik a cirkadián óra és a fotomorfogenikus folyamatok fény általi szabályozásában (Kevei és mtsai, 2007a), kíváncsiak voltunk, hogyan változik a ploidia mintázat különböző fényviszonyok között nevelt lipl mutáns növényekben.

A növényeket 6 napig neveltük folyamatos sötétben, 12:12 LD cikluson, illetve folyamatos, $80 \mu \mathrm{mol}$ foton $\mathrm{m}^{-2} \mathrm{~s}^{-1}$ intenzitású fehér fényen. A ploidia szint emelkedését tapasztaltuk fény/sötét ciklusokon nevelt lip1 mutánsok esetében (10. ábra C és D), valamint a DNS tartalom tovább nőtt a folyamatos fényen nevelt mutáns növényekből származó mintákban (10. ábra E és F). Azonban etiolált lipl mutáns és vad típusú növények között nem tapasztalható eltérés a ploidiát tekintve (10. ábra A és B), ami arra utal, hogy a LIP1 gátló hatása az endoreduplikációra fényfüggő.

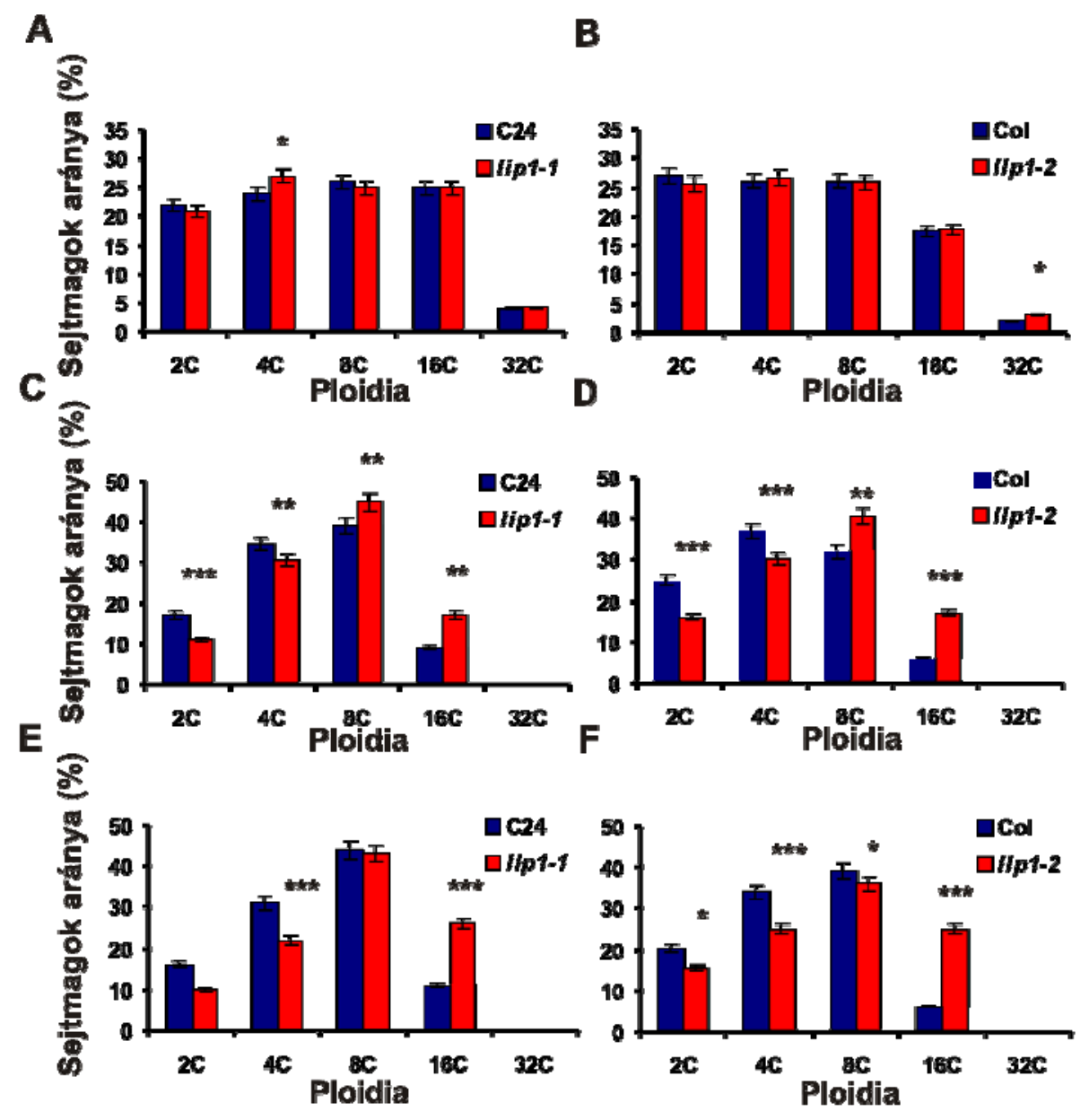

\section{0. ábra. A LIP1 hatása fény-függơ a ploidia szintjẹne}

C24 és lipl-1 (A, C, E), valamìnt Col-0és lipl-2 (B, D, F) növényeket neveltūnk

(A,B) folyamaiossötétben,

(C,D) 12:12LD cikluson,

(E, F) folyamatos $80 \mu \mathrm{mol}$ foton $\mathrm{m}^{-2} \mathrm{~s}^{-1}$ intenzitású fehér fényben 6 napig. A ploidia szint méréséhez teljes csíranöyényeket használtunk. Az adott DNS mennyiséget tartalmazó sejtmagok százalékos arányát tüntettūk fel. Méresenként 4 páhuzzamos mintát vizsgáltunk. A hibahatárok astandant hibát jelölik (SD). 
Folyamatos vörös fényben az endoreduplikáció fény-általi gátlása a fitokróm $\mathrm{B}$ fotoreceptortól függ, mivel sötétben, illetve vörös fényben nevelt fitokróm $B$ mutánsokban egyformán magas ploidia szint mérhető (Gendreau és mtsai, 1998). Hogy teszteljük a LIPl és a fitokróm $B$ közti génkölcsönhatást (episztatikus hatást) a vörös fényfüggő endoreduplikáció szabályozásában, megmértük a kromatintartalmat lip 1-2 és phyB-9 egyszeres, valamint lip1-2 phyB-9 kétszeres mutánsokban.

A növényeket 7 napig neveltük folyamatos vörös fényben $\left(40 \mu \mathrm{mol}\right.$ foton $\left.\mathrm{m}^{-2} \mathrm{~s}^{-1}\right)$, a méréshez teljes csíranövényeket használtunk. Mind a lip-2, mind a phyB-9 egyszeres mutánsok esetében azt tapasztaltuk, hogy a 16-szoros kromatintartalmú magok aránya megemelkedett a mintákban (11. ábra B). A mérés statisztikai analízisét egy utas ANOVA és Tukey-féle eljárás segítségével végeztük el, melyek eredményeként az mondható el szintén, hogy a legkevésbé szignifikáns eltérés a lip-2 phyB-9 és phyB-9 mintapárok között volt. Ez azt jelenti, hogy a lip-2 phyB-9 kétszeres mutáns esetében a két mutáció hatása nem összegződött, a kromatintartalom az egyszeres phyB-9 mutánshoz hasonlóan változott a vad típushoz képest. Vagyis a fitokróm $B$ gén episzatikus hatása érvényesül a LIP1 gén felett. Sötétben nevelt növények esetében a DNS tartalom megegyezett a mutánsokban a vad típuséval, ami a mutációk fényfüggő hatását bizonyítja ismételten (11. ábra A).

Az előző kísérlet mintájára megvizsgáltuk a génkölcsönhatásokat kriptokróm 1 , kriptokróm 2 és lip1-2 között. A növényeket folyamatos kék fényben (40 $\mu \mathrm{mol}$ foton $\left.\mathrm{m}^{-2} \mathrm{~s}^{-1}\right)$ (11. ábra D), neveltük 7 napig, a méréshez teljes csíranövényeket használtunk fel. A lip1-2 mutáns esetében a ploidia szint jelentősen megnőtt folyamatos kék fényben a vad típushoz képest (11. ábra D). A lip1 cryl cry2 háromszoros mutáns kromatintartalma hasonló volt a cry1 cry2 kétszeres mutánshoz. A statisztikai analízis alapján a legkevésbé szignifikáns eltérés a lip-2 cryl cry2 és cryl cry2 mintapárok között volt.

A phyA-211 mutáció hatását folyamatos távoli vörös fényben $\left(5 \mu \mathrm{mol}\right.$ foton $\left.\mathrm{m}^{-2} \mathrm{~s}^{-1}\right)(11$. ábra E) 7 napig nevelt növényeken vizsgáltuk. A lip1-2 mutáns esetében a ploidia szint megkülönböztethetetlen volt a vad típustól folyamatos távoli vörös fényben, míg a lip1-2 phyA-211 dupla mutánsban a kromatintartalom a phyA211 egyszeres mutánssal egyezett meg. Sötétben nevelt phyA-211 és lip1-2 phyA-211 növényekben a ploidia szint nem különbözött a Col-0 -tól, illetve a lip1-2 mutánstól szignifikánsan.

Ezek az adatok arra utalnak, hogy a LIP1 fehérje fontos szerepet játszik az endoreduplikáció kék, illetve vörös fény általi szabályozásában, továbbá úgy tünik, hogy a szignalizációs útban a LIP1 a fitokróm B valamint a kriptokróm 1 és kriptokróm 2 alatt helyezkedik el. 
Egy atipikus E2F transzkripciós faktor, a DEL1 fény által szabályozott transzkripciójáról mutatták ki nemrégiben, hogy fontos szerepet játszik az endoreduplikáció fény-általi szabályozásában (Berckmans és mtsai, 2011). Megvizsgáltuk, hogy a LIP1, illetve a fitokróm B szerepet játszik-e a DEL1 fényfüggő traszkripciójában. A növényeket 7 napig neveltük folyamatos sötétben, illetve folyamatos vörös fényben $\left(40 \mu \mathrm{mol}\right.$ foton $\left.\mathrm{m}^{-2} \mathrm{~s}^{-1}\right)$ a mintaszedést megelőzően. A DEL1 mRNS szintjét mértük vad típusú, lip1-2 és phyB-9 egyszeres, illetve lip1-2 phyB-9 kétszeres mutánsokban valós idejü PCR segítségével. Vad típusú növényekben a DEL1 mRNS szint magasabb volt fényen, mint sötétben (11. ábra F). Azonban, a fénykezelés által okozott emelkedett szintü DEL1 kifejeződés minden mintaában tapasztalható volt (11. ábra F). Ezek az eredmények arra utalnak, hogy vörös fényben a LIP1 és a fitokróm B az endoreduplikációt nem a DEL1 transzkripció befolyásolásán keresztül szabályozzák.

A

C

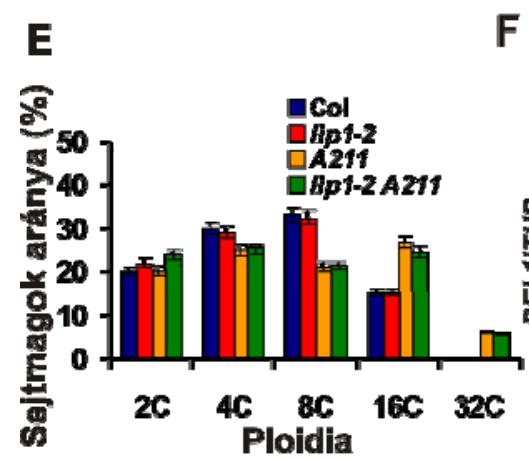

B

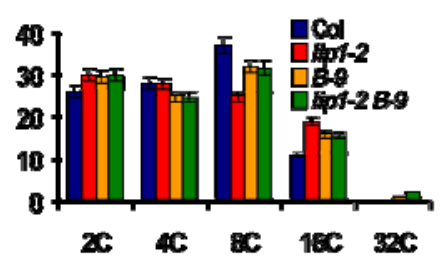

Ploidia

D

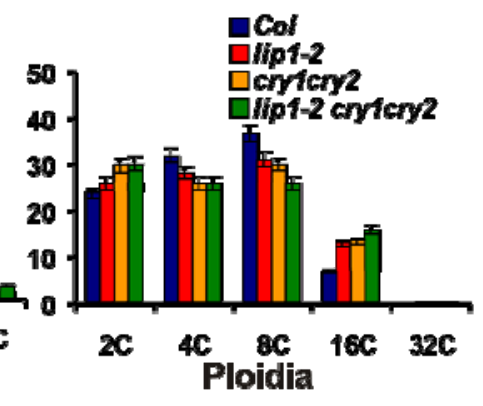

$\mathbf{F}$

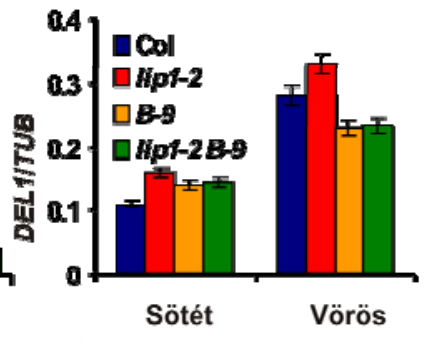

11. å̉bra. A LIP1 fehérje csäkkenti az endoredurplikácíó mértékét vōrōs és kẻk fényhen, de távoli vỏröshen nem Ajelölt genotípusú nōvényeket 7 napig (A, C, F) folyamatos sötetben, $(B, F)$ vörös fênyben

(40 $\mu \mathrm{mol}$ foton $\mathrm{m}^{-2} \mathrm{~s}^{-1}$ ),

(D) kék fênyben (40 $\mu \mathrm{mol}$ foton $\left.\mathrm{m}^{-2} \mathrm{~s}^{-1}\right)$, (E) távoli vörōs fényben ( $5 \mu \mathrm{mol}$ foton $\mathrm{m}^{-2} \mathrm{~s}^{-1}$ ) neveltük. Egessz csíranōvényeket használtunk a ploidia méréshez.

A hibahatárok a standard eltérést (SD) jelölik.

(F) A DELI fẻnyindukált kifejezỏdését valós idejū PCR-al mértīk. Az értékeket TUBULIN mRNS szintre normalizáltuk. Három független mérés átlagát ábrázoltuk. A hibahatárok a standard hibát (SE) jelölik. T-teszt alapjản a mért kũ]lönbségek nem szignifikánsak ( $P>0.1)$ a viżgált körülmények között. A $B-9$ ábrafelirat utal a $P h y B-9, A 211$ a PhyA-2Il mutánsra 


\section{A LIP1 szerepe a fotomorfogenezis szabályozásában a fitokróm B-től és}

\section{a kriptokróm 1-2-től függ, de a fitokróm A-tól nem}

Mint azt korábban laboratóriumunkban már korábban kimutatták, lip1-1 mutáns növényekben a hipokotil hossza vörös és kék fényben megváltozik, a távoli vörös fénytől függő jelátviteli út azonban érintetlen (Kevei és mtsai, 2007a). Hogy többet tudjunk meg a LIP1 szerepéről a fitokrómok és kriptokrómok által szabályozott fényfüggő jelátvitelben, megmértük a hipokotil hosszának változását lip-2 phyB-9, lip1-2 phyA-211, lip1-2 cry1 cry2 többszörös mutánsokban vörös, távoli vörös, illetve kék fényben.

A növényeket nedves szürőpapíron csíráztattuk, majd 4 napra monokromatikus vörös, kék és távoli vörös fénybe helyeztük különböző intenzitásokon. Folyamatos vörös fényben a lip12 mutánsok szik alatti szárának hossza szignifikánsan rövidebb volt, mint a vad típusé, azonban a lip-2 phyB-9 kétszeres mutáns hipokotilja jelentősen hosszabb volt, mint a vad típusé, és csak alig volt rövidebb, mint a phyB-9 egyszeres mutánsé (12. ábra A). Folyamatos kék fényben a lip1-2 mutánsok szik alatti szárának hossza, ha nem is jelentősen, de szignifikánsan rövidebb volt, mint a vad típusé, azonban a lip1-2 cry1 cry2 háromszoros mutáns hipokotilja a cryl cry2 dupla mutánshoz hasonlóan hosszú volt (12. ábra B). Folyamatos távoli vörös fényben a lip 1-2 mutáns a vad típushoz hasonlóan viselkedett, a lip12 phyA-211 dupla mutáns pedig a phyA-211 mutánssal megegyező hipokotil hosszúságú volt (12. ábra C).

Ezek az adatok megerősítik, hogy a LIP1 nem vesz részt a fitokróm A által szabályozott távoli vörös fényfüggő folyamatokban. A lip1 mutáns vörös fényben tapasztalható fotomorfogenikus fenotípusa a fitokróm B által szabályozott jelátviteli út zavarával magyarázható, melyhez kisebb mértékben hozzájárulnak egyéb fitokrómok is (fitokróm $\mathrm{C}, \mathrm{D}$, E). Ezen kívül a lip1 mutáns fenotípusa kék fényben a kriptokróm 1 és kriptokróm 2 fotoreceptoroktól függ. 

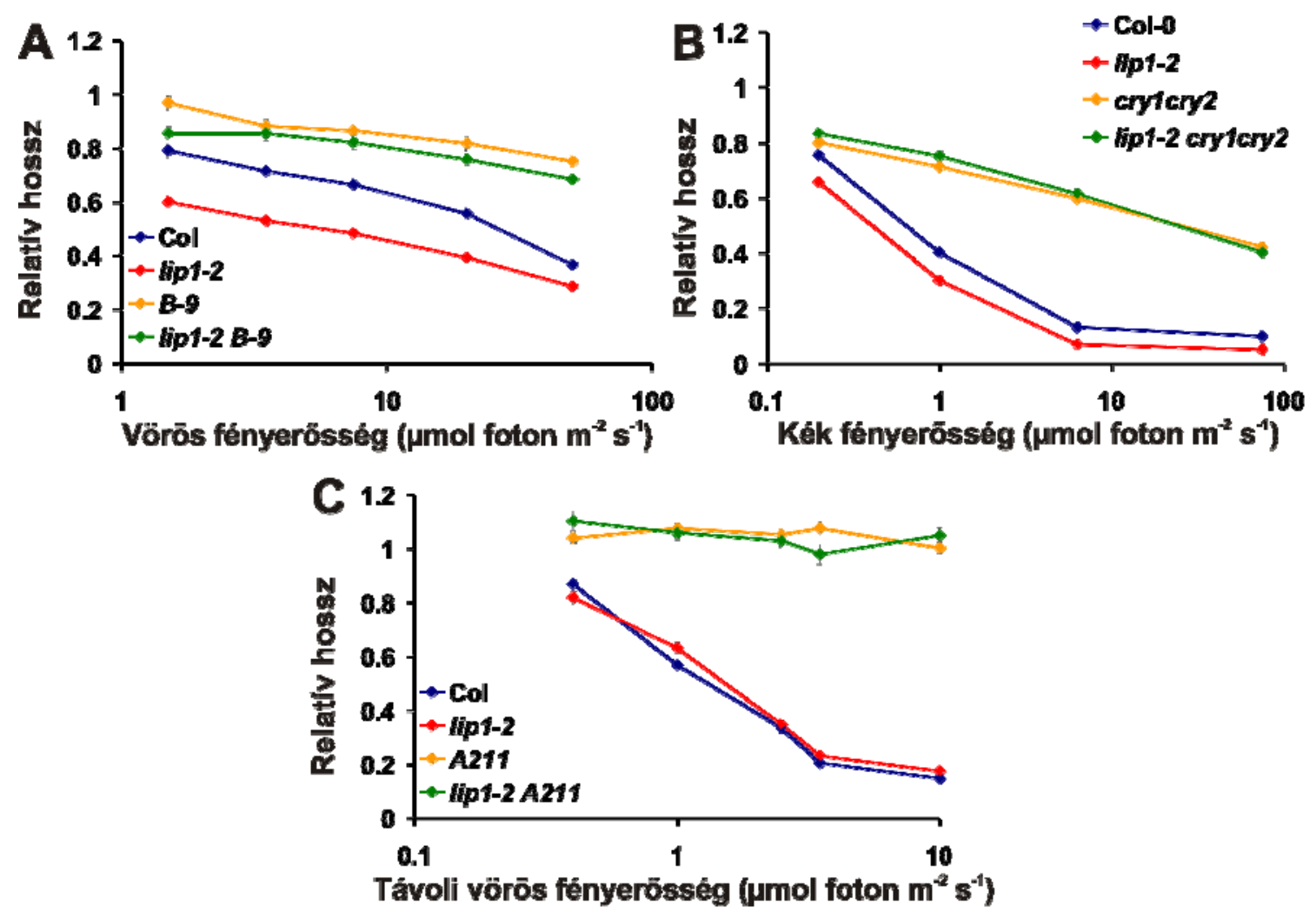

\section{2. ábra. Fényre adott fiziológiai válaszok lïpl-2 mutảnsban}

A csíranōvényeket folyamatos vörös (A), kếk (B), távoli vōrös (C) fênyen neveltük a megadott fënyintenzitásokon 4 napig, majd a növények szik alatti szárának hosszát mértük. Az értékeket sötétben nevelt azonos korú nōvênyek szárának hosszâhoz viszonyitottuk. Az igy kapott értékeket a fênyintenzitás függyényében, logaritmusos skállán ábrázoltuk. Ahibahatárokat standard hibaként adtuk meg (SE), mintánként 28-32 növényt vizsgáltunk. A $B$-9 ábrafelirat utal a $P h y B-9$ mutảnsra, az $A 211$ a $P h y A-211$-re.

\section{A lip1 mutánsok fokozottan érzékenyek az abiotikus stresszre}

Hogy további információkat szerezzünk a LIP1 fehérje funkcióiról, megvizsgáltuk hogyan viselkednek a lip1 mutáns növények különféle abiotikus stressz körülmények között. Azt tapasztaltuk, hogy 12:12 LD cikluson nevelve fokozott érzékenységet mutatnak a tápközeg só ( $\mathrm{NaCl})$ tartalmának emelkedésére (13. ábra). $100 \mathrm{mM} \mathrm{NaCl-ot} \mathrm{vad} \mathrm{típusú} \mathrm{növények} \mathrm{még}$ képesek tolerálni, de a lip1 mutáns csíranövények növekedése és fejlödése ekkor már komoly zavart szenved.

A lip 1-1 mutánsok kevésbé érzékenyek sóra, mint a lip1-2 mutánsok, ami feltehetően ökotípusok közötti különbségekkel magyarázható, mivel a vad típusú C24 növények is toleránsabbak a sóstresszel szemben, mint a Columbia-0 növények. Nemcsak a növekedés és a fejlődés szenved zavart só jelenlétében a lip1 mutáns növényekben, hanem a csírázási képesség is (14. ábra B). 


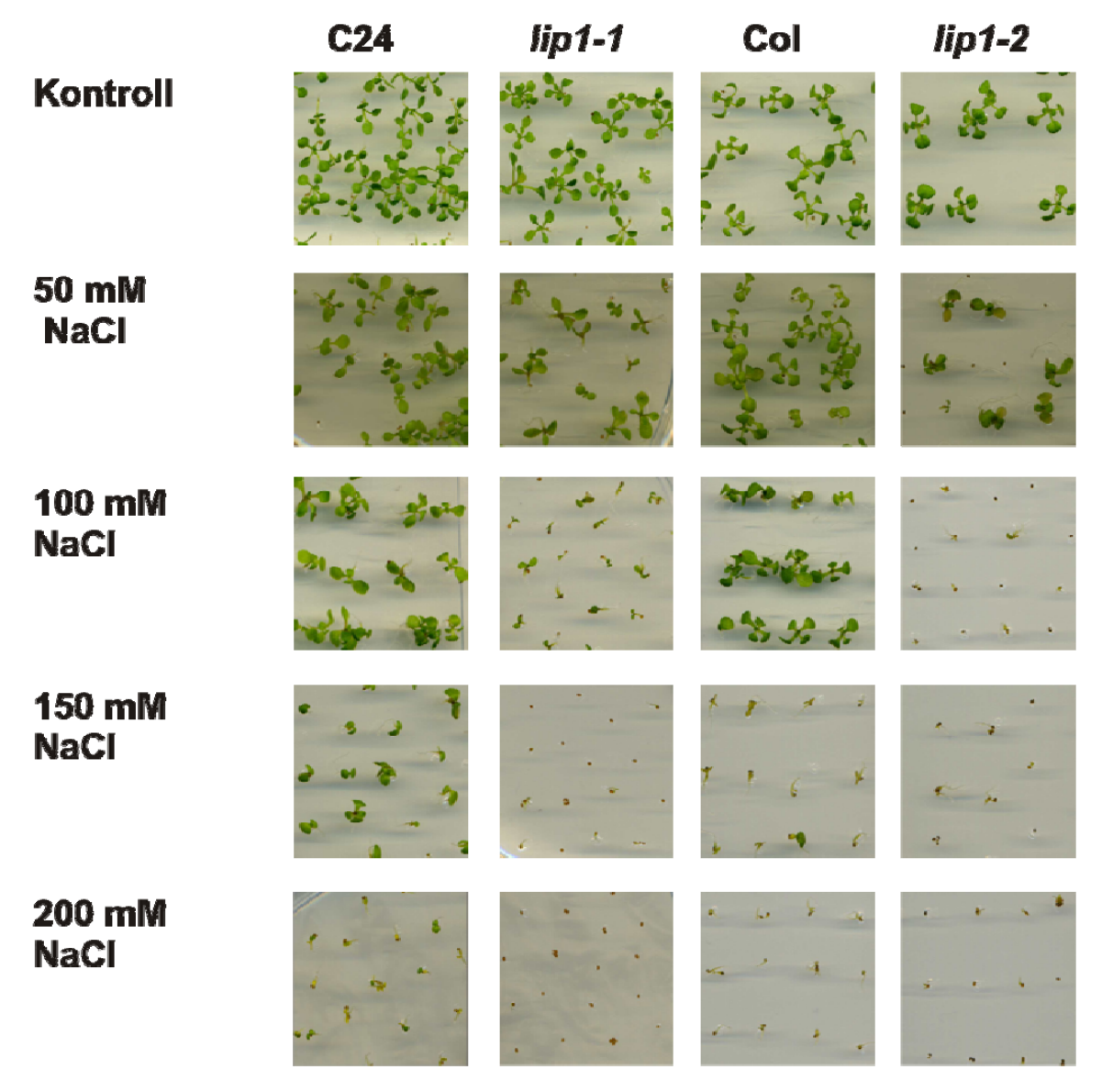

\section{3. álbra. A lipl mutáns uövények érzékenyek a tápközeg sótartalmára}

A csíranövényeket 12:12 LD cikluson neveltük 14 napig a feltüntetett NaCll koncentrációt tartalmazó MS3 táplemezeken. A lip I mutánsok mindkét ökotípus esetében fokozott érzékenységet mutattak a tápközeg sótartalmára.

A csírázási képességet vizsgáltuk a fény/sötét cikluson és a folyamatos sötétben nevelt növények esetében is. Vad típusú (Col-0) és mutáns (lip1-2) növények magjait szélesztettük MS3 táplemezre, valamint $200 \mathrm{mM} \mathrm{NaCl}$ tartalmú MS3 táplemezre. 3 nap $4{ }^{\circ} \mathrm{C}$ hidegkezelés után a magok $22{ }^{\circ} \mathrm{C}$-ra lettek helyezve 12:12 LD cikluson, illetve 4 óra fehér fénykezelés után folyamatos sötétbe. A lip1-2 mutáns növények mindkét esetben érzékenyebbek voltak a vad típusnál a tápközeg magas sókoncentrációjára, utalva ezzel arra, hogy a sóérzékenység nem egy fényfüggő zavar következménye (például a ploidia szint változásáé), viszont a fejlődést minden esetben gátolja. 
$\mathbf{A}$

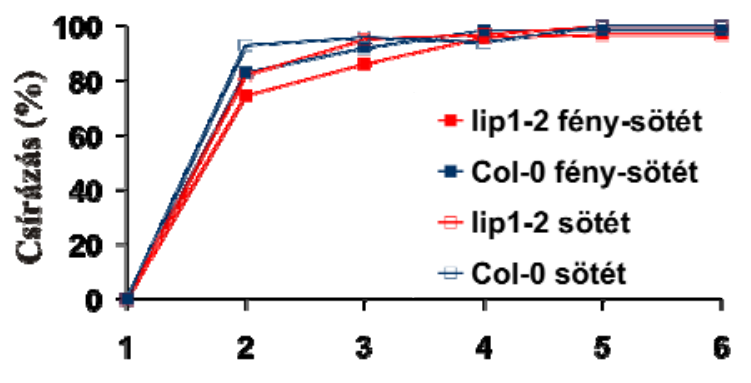

B

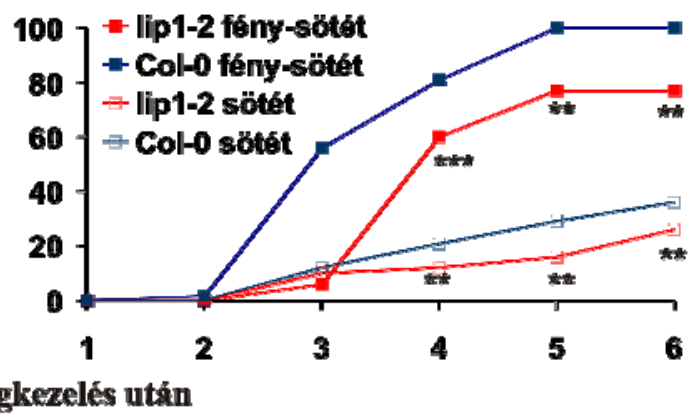

14. ábra. Sástressz hatása na csírñzásra lipp1-2 és Col-0 nōyênyekhen

Vad típusú (Col-0) és mutáns (lip/-2) növények magjaìt szélesztettïk MS3 táplemezre (A), valamint $200 \mathrm{mM}$ $\mathrm{NaCl}$ tartalmú MS3 táplemezre (B). 3 nap $4{ }^{\circ} \mathrm{C}$ hiđegkezelés után a magok $22^{\circ} \mathrm{C}$-ra lettek helyezve 12:12 LD cikluson (telt szimbólumok), illetve 4 óra fehér fĕny kezelés utản folyamatos sōtétbe (üres szimbólumok). A lipl-2 mutánst a piros szin jelöli, a Col-0-t pedig a kék.

A lipl-2 mutánsok csírázási képesságe só tartalmú táptalajon rosszabb, mint a vad típusé a vizsgált fényviszonyok között.

A következő kísérletben azt vizsgáltuk, hogy van-e összefüggés a lip1 mutánsban mérhető rövid periódus és a sóérzékeny fenotípus között. A méréshez a növényeket 12:12 LD cikluson neveltünk 7 napig 100, illetve $50 \mathrm{mM} \mathrm{NaCl}$-dal kiegészített MS3 táptalajon, majd folyamatos gyenge fehér fénybe helyeztük át öket $5 \mu \mathrm{mol}$ foton $\mathrm{m}^{-2} \mathrm{~s}^{-1}$ intenzitáson, szintén 100, illetve $50 \mathrm{mM} \mathrm{NaCl}$-dal kiegészített MS3 táptalajon. A CCR2:LUC markergén ritmikus kifejeződését mértük. A lip1-2 mutáció által okozott rövid periódusú fenotípust a sókezelés nem befolyásolta (5. táblázat).

\begin{tabular}{|c|c|c|c|}
\hline Vonal & NaCl & Periódushossz (óra) & I SEM \\
\hline Col-0 & - & 25.94 & 0.17 \\
Col-0 & $50 \mathrm{mM}$ & 25.78 & 0.19 \\
lipl-2 & - & 24.56 & 0.08 \\
lipl-2 & $50 \mathrm{mM}$ & 24.7 & 0.26 \\
& & & \\
Col-0 & - & 25.32 & 0.48 \\
Col-0 & $100 \mathrm{mM}$ & 25.81 & 0.32 \\
lipl-2 & - & 24.06 & 0.37 \\
lipl-2 & $100 \mathrm{mM}$ & 24.3 & 0.51 \\
\hline
\end{tabular}

\section{5. táblázat. A sóstressz nincs hatással a ĥp 1-2 mutáció okozta perióctus rövidũlésre}

A növényeket 12:12 LD cilcluson neveltünk 7 napig 100 illetve $50 \mathrm{mM} \mathrm{NaCl-dal} \mathrm{kiegészitett} \mathrm{MS3} \mathrm{táptalajon,}$ majd folyamatos gyenge fehér fernybe ( 5 umol foton $\left.\mathrm{m}^{-2} \mathrm{~s}^{-1}\right)$ helyeztïk ôket, szintén 100 illetve $50 \mathrm{mM} \mathrm{NaCl-dal}$ kiegészített MS3 táptalajon. A CCR2:LUC markergén ritmikus kifejezódését mértük. A periódushossz mérést a BRASS2 program segítségével végeztuik. A lip I-2 mutáció által okozott rövid periódusra a sókezelés nem volt hatással. 
A csírázás gátlása mellett a magas $\mathrm{NaCl}$ koncentráció zavart okoz a gyökér fejlődésében is. A növényeket 7 napig neveltük 12:12 LD cikluson MS3 táptalajon, majd áthelyeztük öket függőleges helyzetü, különböző koncentrációjú $\mathrm{NaCl}$ tartalmú lemezekre. A 15. ábra mutatja, hogy a gyökér növekedését a só erőteljesebben gátolja lip1 mutánsban, mint a vad típusban.

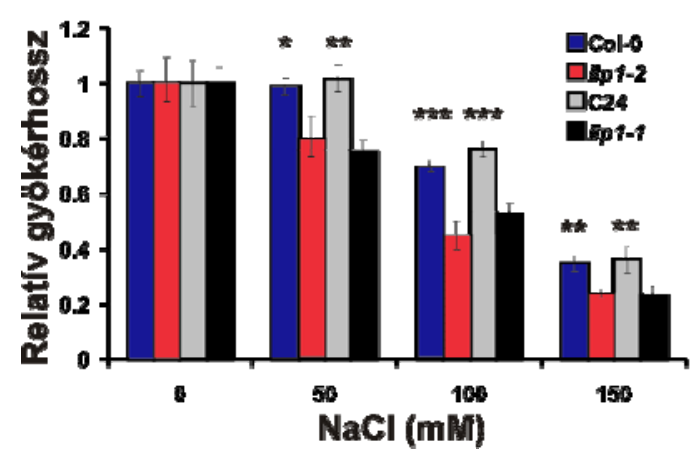

15. áhra. A só gấtolja a hịp1 növények gyäkérfejläđését Col-0, lipl-2, C24 és lipI-I növényeket 7 napig neveltünk 12:12 LD cikluson, majd eltérỏ $\mathrm{NaCl}$ tartalmú, függőleges helyzetū lemezekre helyeztưk ổket. A gyōkérhosszt az áthelyezést követó 7. napon mértük. Az értékeket sómentes táptalajon nevelt nõvények gyökérhosszára normalizáltuk.

A hibahatárok a standard hibát jelölik (SE), a mintaszám mérésenként 17-20 volt.

A magas sókoncentráció ozmotikus és ionikus stresszt is jelent a növények számára. Az ozomotikus stressz korai stresszválasz gének indukciójához vezet. Ilyen gének az RD29A, $R D 29 B$ és a $R A B 18$. Az ionikus stressz (emelkedett $\mathrm{Na}^{+}$koncentráció a sejten belül) pedig az SOS2 indukcióját idézi elő, ami egy $\mathrm{Na}^{+} / \mathrm{H}^{+}$antiporter, az SOS1 aktivátora (Batelli és mtsai, 2007). Hogy megvizsgáljuk a LIP1 részt vesz-e ezekben a folyamatokban, 7 napos 12:12 LD cikluson nevelt lip1-2 mutáns és vad típusú növényeket helyeztünk $200 \mathrm{mM} \mathrm{NaCl}$ tartalmú táplemezre. 3 óránként mintát szedtünk és valós idejü PCR segítségével vizsgáltuk az RD29A (Yamaguchi-Shinozaki és Shizonaki, 1993), RD29B (Yamaguchi-Shinozaki és Shizonaki, 1993), RAB18 (Ciereszko és Kleczkowski, 2002) és SOS2 (Batelli és mtsai, 2007) gének só indukált kifejeződését. A 16. ábra mutatja, hogy nem volt jelentős különbség az indukció kinetikájában és mértékében egyik gén esetében sem a mutáns és a vad típus között. Ezek az adatok arra engednek következtetni, hogy a LIP1 szerepe elhanyagolható a só érzékelés jelátviteli folyamatában és a vizsgált sóstressz által indukálható gének transzkripciójának aktivációjában. Lehetséges azonban hogy a LIP1-nek nem transzkripciós szinten, hanem például poszt-transzlációs módosítások, vagy a sejten belüli elhelyezkedés változtatásának szintjén van szerepe ezen komponensek esetében. 

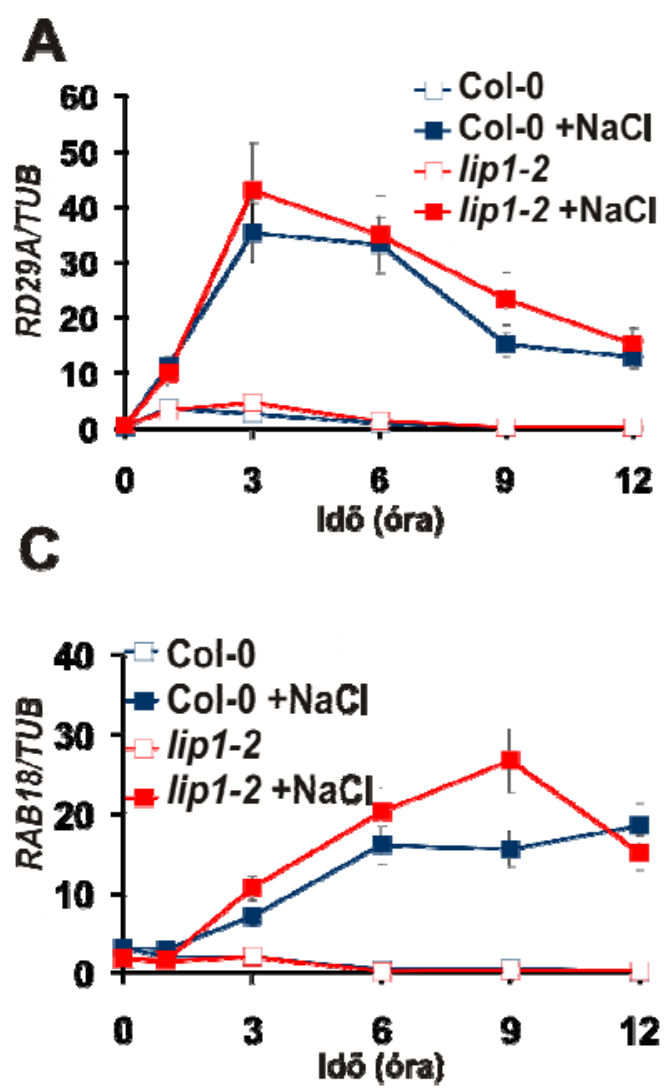

B
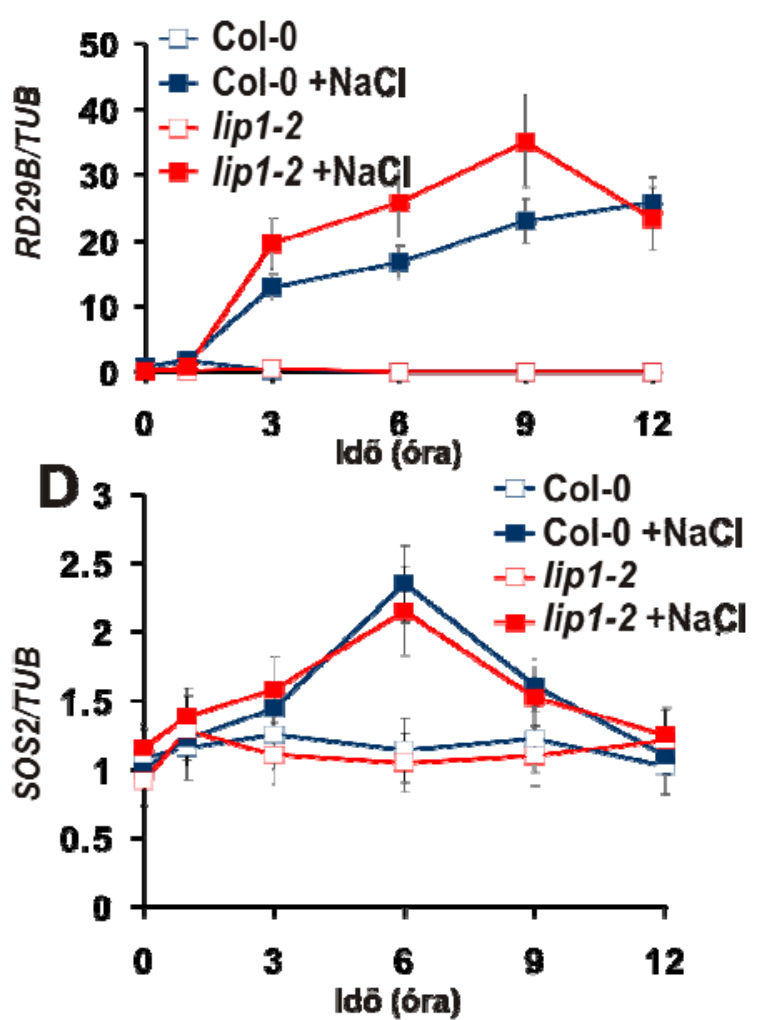

16. åbra. A LIP1 hatása a sóstresszel indukảlható gének expressziójára

Vad túpusá és lip 1-2 mutáns növényeket neveltữnk 7 napig 12:12 LD cikluson, majd helyeztūnk át $200 \mathrm{mM}$ $\mathrm{NaCl}$ tartalmí táptalajra 0 idôponthan. Mintaszedés a jelölt idōpontokban tơntént. $R D 29 A(\mathrm{~A}), R D 29 B(\mathrm{~B})$, RAB IS (C) és a SOS2 (D) gének kifejezódését vizsgâltuk valós idejū PCR segitségével.

Azértékeket TUBULIN szintjére normalizảltuk. Két független mérés eredményeinek ảtlagát ábrảzoltuk.

A hihahatárok a standard hibát(SE) jelzik.

Megvizsgáltuk hogyan képesek fejlődni a lip1-2 mutáns növények különféle ionikus $\left(\mathrm{K}^{+}\right.$, $\left.\mathrm{Cs}^{2+}, \mathrm{Li}^{2+}\right)$, ozmotikus és hőmérsékleti stresszhatások alatt, valamint hogyan változik a fejlődés, illetve a csírázás ABA hatására, ami bizonyos stressz-válaszutak fontos szabályozó eleme. Az ionikus-stressz vizsgálatok során azt tapasztaltuk, hogy a lip1 mutánsok 12:12 LD cikluson nevelve fokozott érzékenységet mutatnak a tápközeg $\mathrm{CsCl}_{2}(10 \mathrm{mM}), \mathrm{KCl}(150 \mathrm{mM})$, $\mathrm{LiCl}_{2}(20 \mathrm{mM})$ tartalmára egyaránt (17. ábra). Ez arra utal, hogy a lipl mutánsban nem specifikusan a nátrium érzékenység szenved zavart, és részben magyarázza, hogy a valós idejü PCR vizsgálatok során miért nem tapasztaltunk eltérést az SOS2 indukciójában. Az ozmotikus stresszre adott választ $250 \mathrm{mM}$ mannitolt tartalmazó táplemez segítségével vizsgáltuk. A lip 1-2 mutánsok ebben az esetben is érzékenyebbnek bizonyultak a vad típusnál (17. ábra). A hőmérséklet stressz során ismételten azt tapasztaltuk, hogy a lip1-2 mutáns növények fokozottan érzékenyen reagálnak a hőmérséklet emelkedésére. Ezen kísérlet során a növényeket 7 napig neveltük 12:12 LD cikluson $22{ }^{\circ} \mathrm{C}$-on, majd 2 napra $37^{\circ} \mathrm{C}$-ra helyeztük át öket. A 2. nap elteltével a növények visszakerültek $22{ }^{\circ} \mathrm{C}-$ ra további 7 napra. A lip 1-2 
mutánsok nem élték túl a kezelést, viszont a vad típusú növények normális fejlödést mutattak a 16. napon (17. ábra).
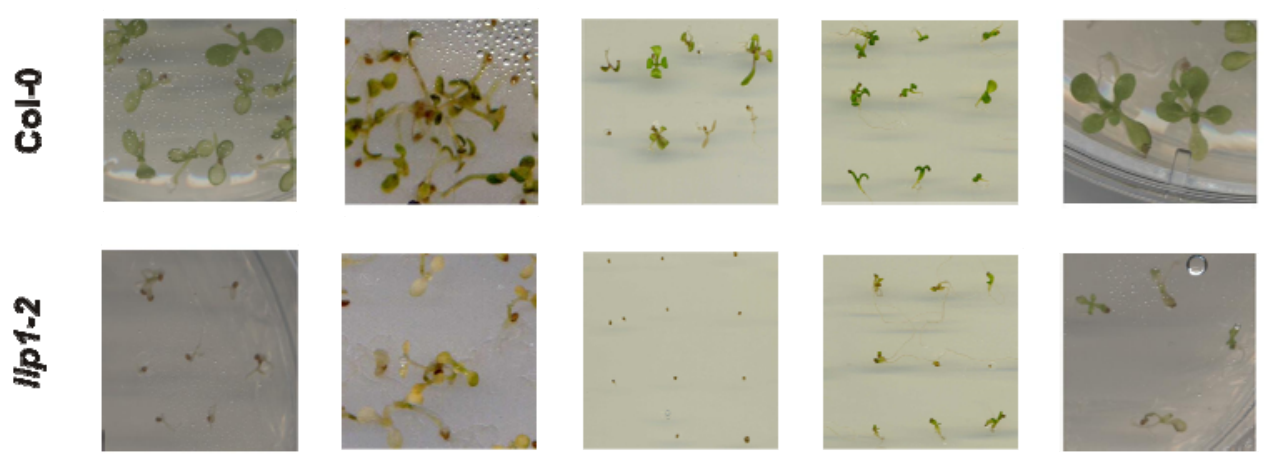

A

B

$\mathrm{CsCl}_{2}$

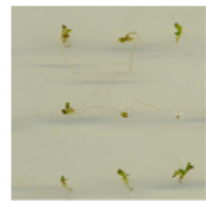

D

mannitol

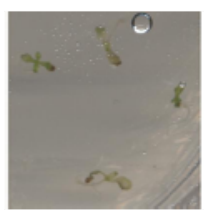

E

hö

17. ả̉bra. Ionikus, ozmotikus és hởmérsékJeti stressz hatása a lịp1-2 mutáns nōvẽnyekre

Col-0 és lip I-2 mutảns növényeket neveltīnk 14 napig 12:12 LD cikluson

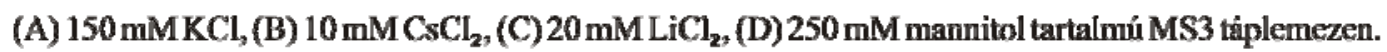

(E) A hơmérséklet șiressz vizsgálatához a nōvényeket 7 napigneveltūk 12 :12 LD cikluson

$22^{\circ} \mathrm{C}$-on, majd 2 napra $37^{\circ} \mathrm{C}$-ra helyeztūk át $\delta$ ket. A2 nap elteltével a nōvények visszakesīiltek $22^{\circ} \mathrm{C}$-ra további 7 napra. A lipl-2 mutánsok a vizsgált körülmények kỗzōtt érzékenyebbnek bizonyultak a stresszhatásokra a vad típusnảl.

Az ABA amellett, hogy fontos szerepe van stressz jelátviteli utak szabályozásában, csírázást gátló hatással is bír. Ezért megvizsgáltuk, hogy lip 1-2 mutáns növények hogyan képesek csírázni 0.3 és $0.5 \mathrm{mM}$ ABA tartalmú táplemezen. Azt tapasztaltuk, hogy a lip1-2 mutánsok csírázási képessége sokkal rosszabb ABA tartalmú táplemezen, mint a vad típusé (6. táblázat). A LIP1 negatívan szabályozza az ABA jelátvitel ezen ágát. Az RD29A és RD29B, valamint a $R A B 18$ az ABA-függő jelátviteli útvonal komponensei, kifejeződési mintázatuk azonban nem változott a lip1 mutánsban a vad típushoz képest (16. ábra).

Ezek a mérési eredmények arra utalnak, hogy a LIP1 többféle stresszfolyamatban is részt vesz, és feltehetően egy olyan cirkadián órát szabályozó elem, amely összeköttetéssel bír a cirkadián óra és a stressz folyamatok között. Egyre több cirkadián óra komponensről derült ki a közelmúltban, hogy szerepet játszik különféle stresszfolyamatok szabályozásában, illetve összeköttetést biztosít az óra és a stressz-válaszok között, hogy a növények a legmegfelelöbb időpontban legyenek felkészülve az őket várható módon érő stresszhatásokra (pl. hidegstressz hajnalban, szárazságstressz délben) (Sanchez és mtsai, 2011). 


\begin{tabular}{|c|c|c|c|c|}
\hline Csirázási arány (\%) & lipl-2 & Col-0 & lipl-I & C24 \\
\hline kontrol & $90+/-5$ & $97+/-2$ & $91+/-5$ & $96+/-2$ \\
$0.3 \mu$ M ABA & $25+/-3$ & $92.5+/-4$ & $66+/-12$ & $78.5+/-8$ \\
$0.5 \mu M$ ABA & $9.2+/-1.5$ & $85+/-2$ & $55+/-4$ & $65+/-2$ \\
\hline
\end{tabular}

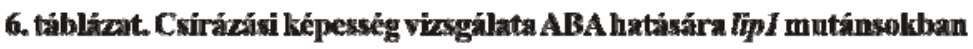

Col-0, lipl $1-2, \mathrm{C} 24$ és lippl-1 nơvények magjait $4^{0} \mathrm{C}$-on hidegkezeltunk 3 napig, majd $22^{\circ} \mathrm{C}$-on ABA tartalmú táplemezen folyamatos gyenge fehér fänybe helyeztük. A4, napon vizsgáltuk a çírárisi képessśget . Mind a lipl-2, mind a lipl-l rosszabb csirízísi kẻpességet mutatott mint a vad típus.

\section{A LIP1 sejten belüli elhelyezkedése}

\section{A sejten belüli elhelyezkedés módosítása}

Korábban már kimutattuk, hogy a LIP1 fehérje a citoplazmában és a sejmagban is egyaránt jelen van, valamint hogy eloszlását sem a fényviszonyok, sem a cirkadián óra nem befolyásolja (Kevei és mtsai, 2007a). Felmerült a kérdés, hogy a fent említett pleiotróp fenotípusok köthetőek-e sejten belüli elhelyezkedéshez, ezért olyan növényeket állítottunk elő, amelyek a lip1-2 mutáns háttérben YFP-LIP1 fúziós fehérjét fejeznek ki nukleáris lokalizációs szignállal (NLS), illetve nukleáris export szignállal (NES) ellátva (18. ábra A). Olyan transzgenikus vonalakat választottunk ki a további kísérletekhez, amelyekben a kifejeződési szintek összemérhetőek voltak (18. ábra B). A LIP1 fehérje mennyiségi vizsgálatát immunoblot módszerrel végeztük. A növényeket folyamatos fehér fényen (50 $\mu$ mol foton $\mathrm{m}^{-2} \mathrm{~s}^{-1}$ ) neveltük 4 napig a mintaszedést megelözően. A LIP1 fúziós fehérjék sejten belüli elhelyezkedését epifluoreszcens mikroszkópiával vizsgáltuk. A növényeket 10 napig neveltük 12:12 LD cikluson a mikroszkopizálást megelőzően. Az YFP-LIP1 fúziós fehérje detektálható volt a sejtmagban és a citoplazmában is, az YFP-LIP1-NLS a sejtmagban volt jelen, míg az YFP-LIP1-NES esetében az YFP jel a sejtmagban nem volt kimutatható (18. ábra C). 


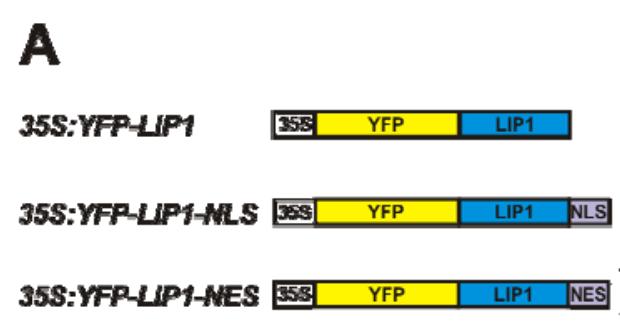

18. ảbra. YFP-LIP1 fủziés fehérje sej ten belîli lokalizáciôjảnak módosítása

(A) LIPI füziós konstrukciók sematikus ábrája.

YFP: yellow fluorescent protein; $N L S$ : magi lokalizációs szignả; NES: magi export szignál. A kifejezôdést dohánymozaik vírus 35S promotere biztosítja.

B
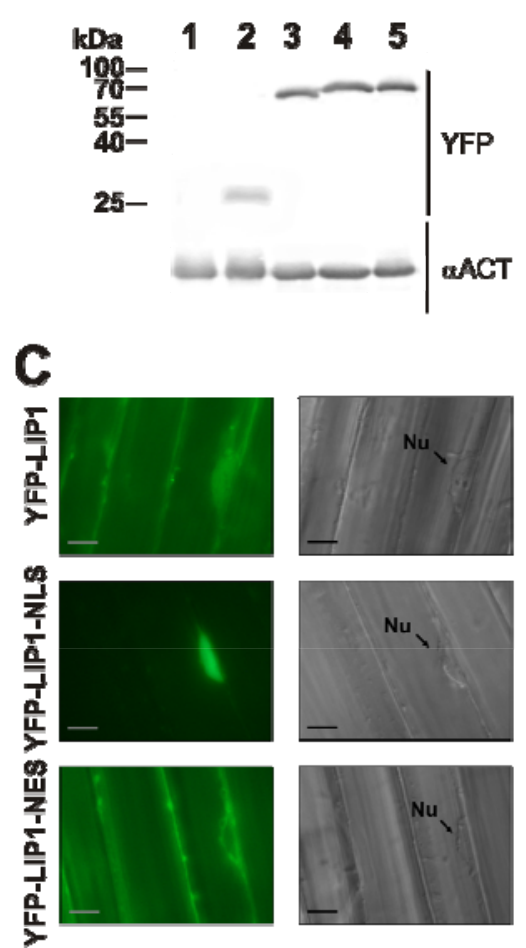

(B) LIP1 fehérje mennyiségi vizsgálata immunoblot módszerével. A nōvényeket folyamatos $50 \mu \mathrm{mol}$ foton $\mathrm{m}^{-2} \mathrm{~s}^{-1}$ intenzitású fehér fềnyen neveltük 4 napig a mintaszedést megelözöen.

(1) Nem transzformált Col-0,

(2) YFP-t 35S promoterről kifejezō Col-0, valamint

(3) YFP-LIP1,

(4) YFP-LIP1-NLS,

(5) YFP-LIP1-NES fỉziós fehérjèt kifejezó lip 1-2 mutáns.

Két egyforma gélt blottoltunk és kezeltünk YFP illetve aktin (aACT) specifikus ellenanyaggal. A bal oldalon látható fehérje molekulasúly marker az YFP-specifikus jelek méretét mutatja.

(C) YFP-LIPI füzziós fehérje sejten belüli elhelyezkedése.

A növényeket 10 napig neveltük 12:12 LD cikluson a mikroszkopizailást megelôzóen. A bal oldalon az epifluoreszcens képek, a jobb oldalon a referencia képek láthatóakYFP-LIP1, YFPLIPI-NLS és YFP-LIP1-NES füziós fehérjêket kifejezõ lip 1-2 nōvények szárának börszöveti sejteirōl.

Askála 10 um-t jelöl, nu: sejtmag.

\section{A LIP1 fehérje sejtmagi elhelyezkedése esszenciális a cirkadián funkció ellátásához}

A kiválaszott transzgenikus vonalakban vizsgáltuk a ploidia, só, fotomorfogenikus és cirkadián fenotípusok komplementálhatóságát. A növényeket folyamatos fehér fényen (80 $\mu$ mol foton $\mathrm{m}^{-2} \mathrm{~s}^{-1}$ ) neveltük 7 napig a ploidia méréshez. A 19. A ábra mutatja, hogy a lip1 mutáns háttérben kifejezett YFP-LIP1, YFP-LIP1-NES és YFP-LIP1-NLS fúziós fehérjék képesek helyreállítani a mutáció által okozott ploidia szint változást. Legjobban szemlélteti ezt a 16C DNS tartalmú magok aránya. A ploidia szinthez hasonlóan, a jellegzetes karéjos sejtalak is helyreállt a sziklevelek epidermisz sejtjein a komplementáló vonalakban (19. ábra B). A sejtalakot 7 napig folyamatos fehér fényen nőtt növények sziklevelének felszíni börszöveti sejtjein vizsgáltuk. 


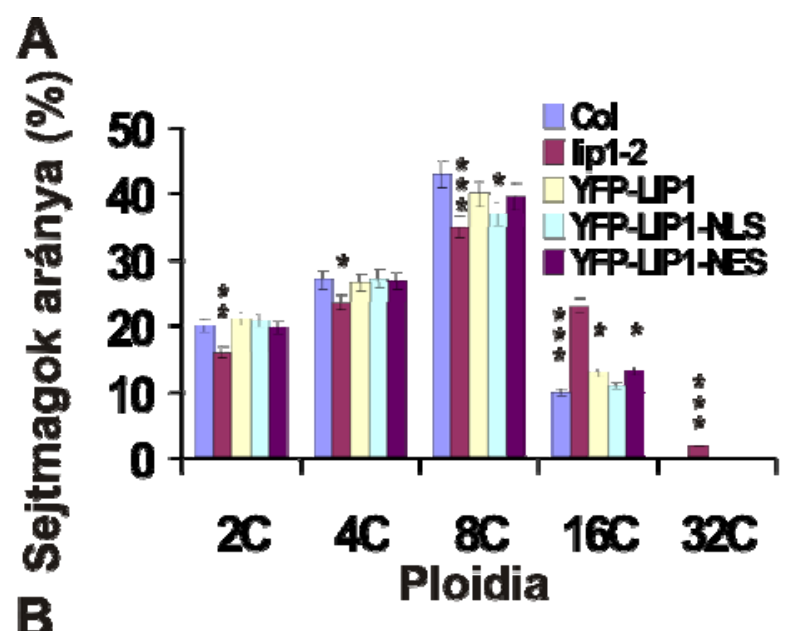

\section{YFP-LIP1 YFP-LIP1-NES YFP-LIP1-NLS}
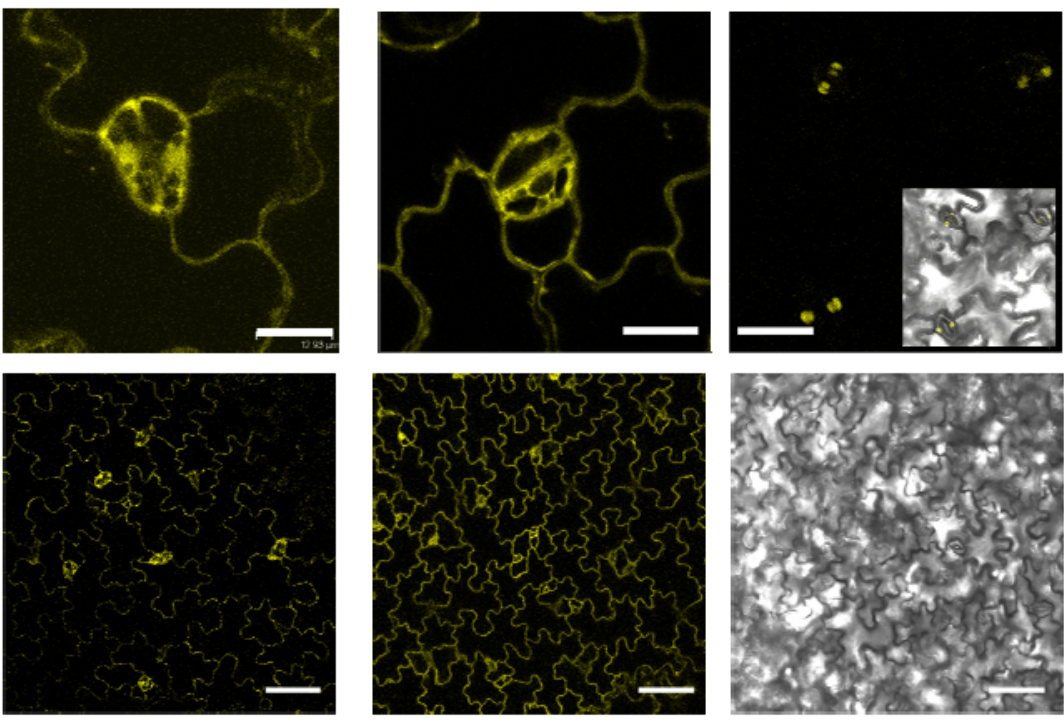

19. ábra. A ploidia és a bőrszōveti sejtalak fenotípus komplementálása LIPI fóziós fehérjékkel lipi-2 háttérben

Anövényeket folyamatos fehér fényen ( $80 \mu \mathrm{mol}$ foton $\mathrm{m}^{-2} \mathrm{~s}^{-1}$ ) neveltük 7 napig a vizsgálatokat megelözően.

(A) Ploidia szintek Col-0, lip1-2 mutáns és YFP-LIP1, YFP-LIP1-NLS vagy YFP-LIP1-NES füziós fehérjéket kifejezô lip 1-2 mutáns nôvényekben. Mérésenként 4 párhuzamos mintát vizsgáltunk.

Alibahatárok a standard eltérést(SD) jelölik.

(B) A szikleveleket fluoreszeens mikroszkóppal vizsgáltuk, kivéve az YFP-LIP1-NLS vonalat, ahol fénymikroszkớpot használtunk. Mivel a fluoreszcens jel ebben a vonalban a sejtmagra korlátozódik és nem rajzolódik ki emiatta sejtek kontúrja. A kis képen látható a fluoreszcens és a fénymikroszkópos kép âtfedése.

Askála a felsõ sorban 13 , az alsósorban $50 \mu \mathrm{m}-\mathrm{t}$ jelöl.

A füziós fehérjékkel mindkét vizsgált fenotipus komplementálható volt. 
Vizsgáltuk a fúziós fehérjéket kifejező növényvonalak sótürő képességét is. A kontroll és a fúziós fehérjéket kifejező lip1-2 mutáns növényeket 14 napig neveltük $100 \mathrm{mM}$ NaCl-ot tartalmazó táplemezen.. Az YFP-LIP1, YFP-LIP1-NLS, YFP-LIP1-NES fúziós fehérjéket kifejező lip1-2 mutáns növények képesek voltak tolerálni 100 mM NaCl-ot a tápközegben, akárcsak a vad típusú növények (20. ábra).

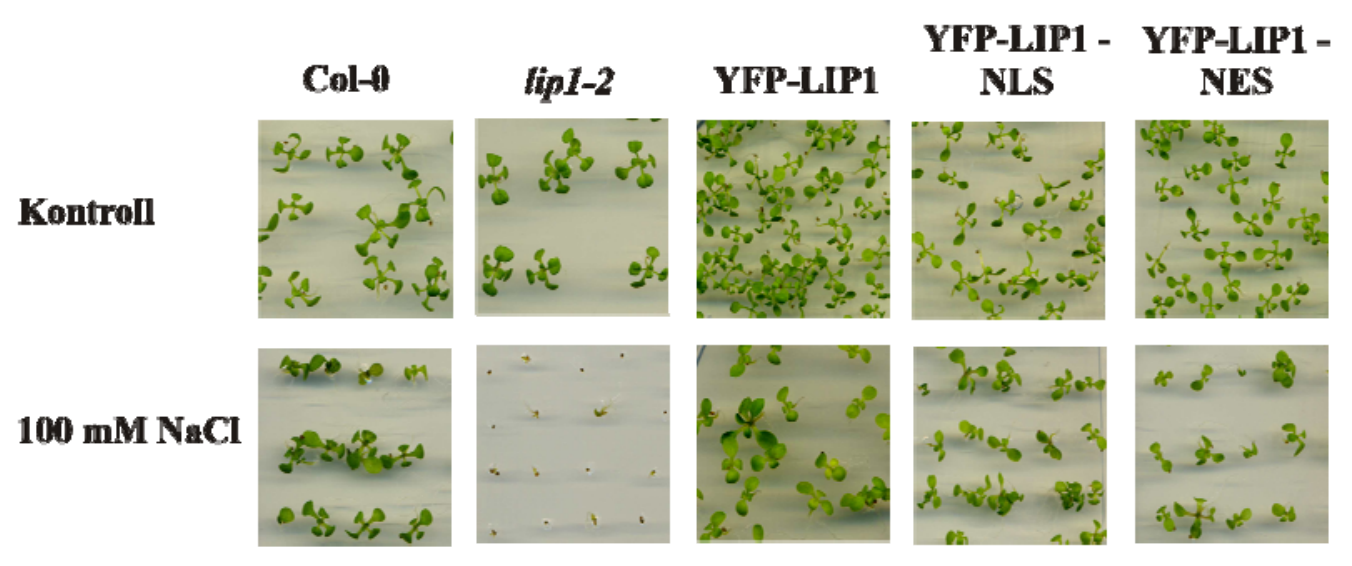

20. áhra. ALIP1 fúziós fehérjékkel komplementált lip1-2növênyeknem tólérzékenyek sóstresszze.

Col-0, lip J-2, valamint YFP-LIP1, YFP-LIP1-NLS, és YFP-LIPI-NES füziós fehériéket lip 1-2 mutáns háttéren kifejezỗ nōvényeket 12:12 LD cikluson neveltünk $22^{\circ} \mathrm{C}$-on 14 napig MS3 és $100 \mathrm{mM} \mathrm{NaCl-al} \mathrm{kiegészített} \mathrm{MS3}$ táptalajon. A komplementáló konstrukciókat hordozó mutáns vonalak egyike sem mutatott a vad típusnál nagyobb mértêkñ érzékenysśget a tấpközeg sótartalmára.

A fotomorfogenikus fenotípus vizsgálatához a fúziós fehérjéket lip 1-2 háttérben kifejező csíranövényeket különböző intenzitású monokromatikus vörös (21. ábra A), kék (21. ábra B), távoli vörös (21. ábra C) fényen neveltük 4 napig, majd a növények szik alatti szárának hosszát mértük. A szik alatti szár hossza nem tért el szignifikánsan a komplementáló vonalak esetében a vad típustól vörös, kék, illetve távoli vörös fényben sem. A mérési eredmények alapján a LIP1 fehérje kompartmentalizációja nem szükséges ezekben a funkciókban betöltött szerepéhez. Vagyis nem zárható ki, hogy az a minimális mennyiségü fehérje, ami az NLS/NES motívum ellenére is a citoplazmában/sejtmagban helyezkedik el, elegendő a sikeres komplementáláshoz. 


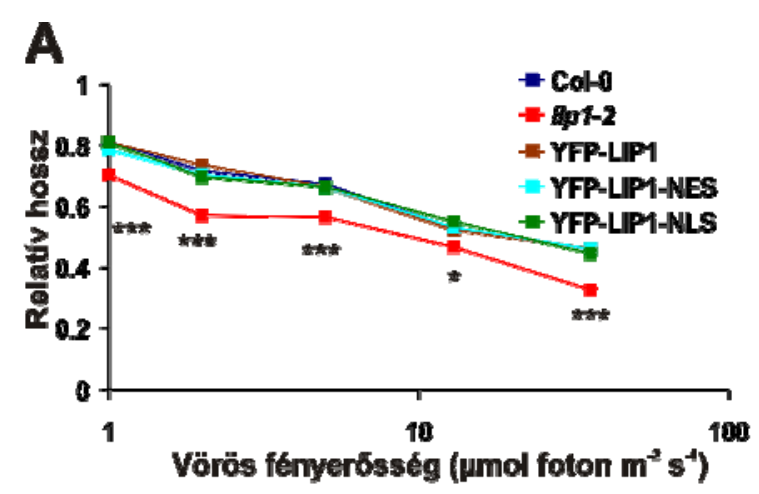

B
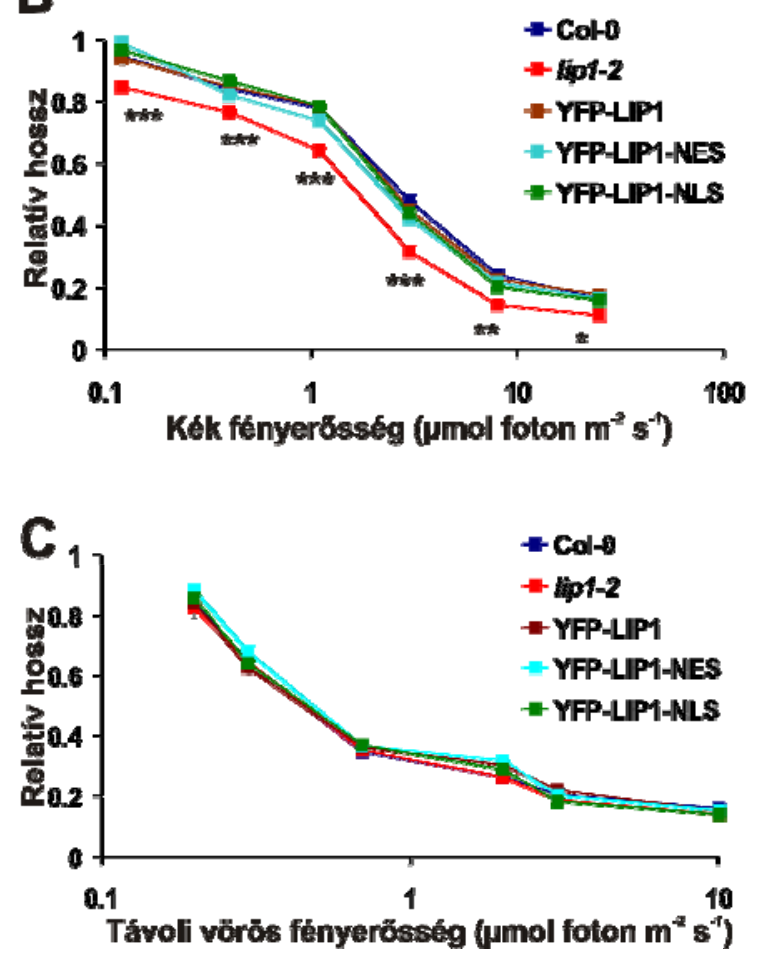

21. ábra. lipI-2 mutáns fotomorfogenikus fenotípusának komplementả̉ása LIP1 fúziós fehérjékkel

Hipokotil megnyúlás fểnyvãlasz görbéje

(A) folyamatos vōrỗs,

(B) kék ,

(C) távoli-vōrös fẻnyben.

Col-0, lipl-2,

valamint YFP-LIP1, YFP-LIP1-NLS és YFP-LIP1NES fúziós fehérjéket lipl-2 háttérben kífejezó növényeket neveltũk a megadott fényintenzitásokon négy napig majd a növények hipokotilhosszát mértük. Az értékeket sötétben nevelt azonos konú növẻnyek szárának hosszához viszonyítottuk. Az így kapott értéket a fênyintenzitás tüggvényẻben, logaritmusos skálán ábrázsıltuk.

A hibahatárokat standard hibaként adtukmeg (SE), a mintaszám 28-32 volt mérési pontonként.

A fẽnyviszonyoktól függetlenül nem tapasztaltunk szignifikảns eltérést a vad típus és a füziós fehérjéket kifejező vonalak kōzött.

Teszteltük a cirkadián fenotípus komplementálhatóságát is. A fúziós fehérjéket kifejező lip1-2 mutáns növényeket 12:12 LD cikluson neveltünk 7 napig, majd folyamatos $3 \mu \mathrm{mol}$ foton $\mathrm{m}^{-2} \mathrm{~s}^{-1}$ intenzitású vörös fénybe helyeztük át. A CCR2:LUC markergén ritmikus kifejeződését mértük. Az YFP-LIP1 és YFP-LIP1-NLS fúziós fehérjéket kifejező lip1-2 mutánsok esetében a mutáció okozta rövid periódus nem látható (22. ábra A és B; 7. táblázat), míg az YFP-LIP1-NES-t kifejező vonalak esetében a periódus a lip1-2 mutánsban mérhető periódushosszal egyezett meg (22. ábra C, 7. táblázat). 

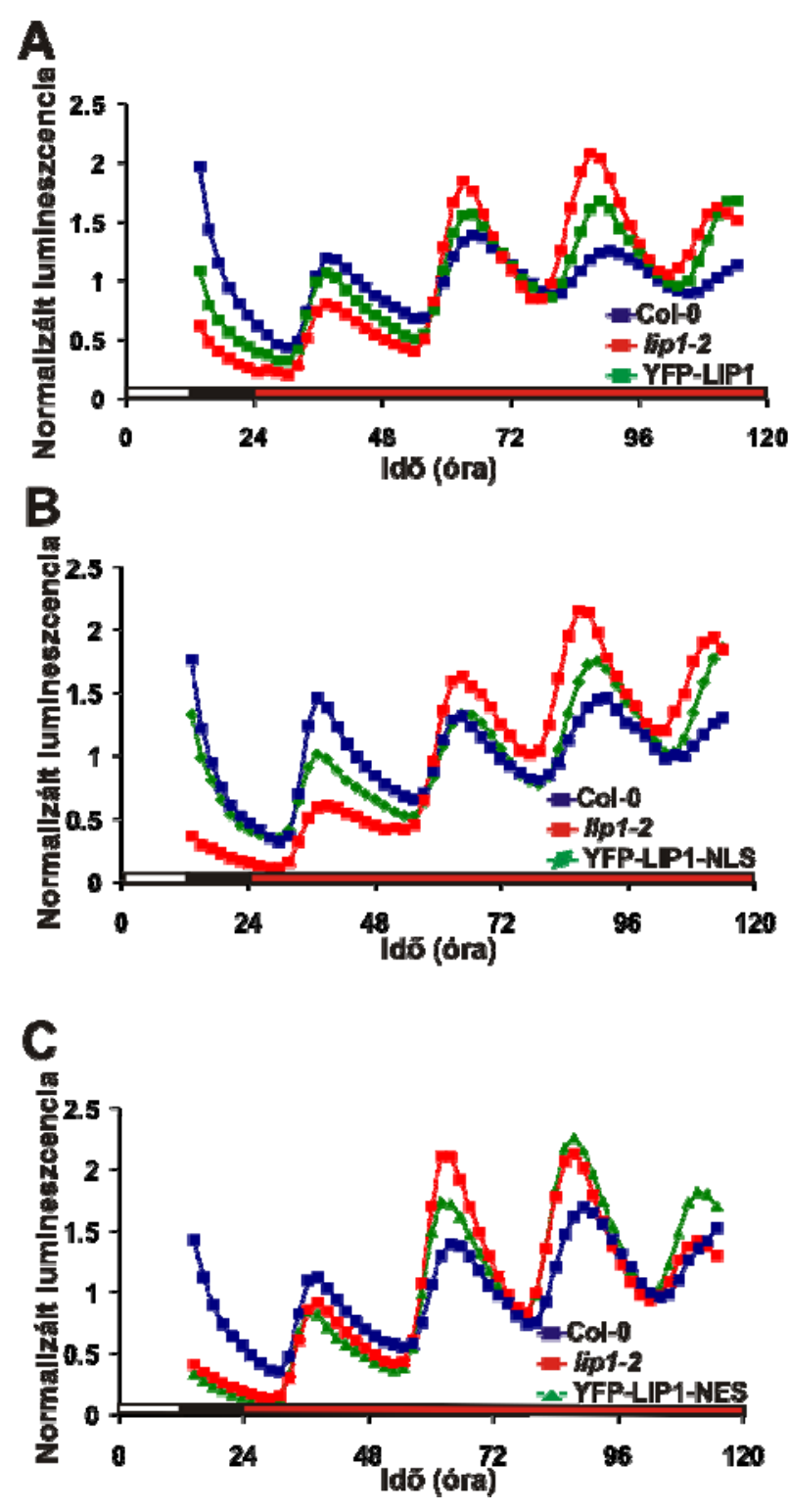

22. ábra. lipi-2 mutảns cirkadián fenotípusának komplementálása LIP1 fúziós fehêrjểkkel

Col-0, lipl-2, valamint

(D) YFP-LIP1,

(E) YFP-LIP1-NLS,

(F) YFP-LIPI-NES fuzziós fehérjéket kifejezō lipl-2 mutáns nôvénycket 12:12 LD cikluson neveltuink 7 napig, majd folyamatos $3 \mu \mathrm{mol}$ foton $\mathrm{m}^{-2} \mathrm{~s}^{-1}$ intenzitásí vörös fẽnybe helyeztük át.

A CCR2:LUC markergén ritmikus kifejezōdését mértük, a feltūntetett értékek az átlagra lettek normalizálva.

Három független transzgenikus vonalat mértünk minden konstrukcióra nézve ugyanazzal az eredménnyel. Az YFP-LIP1 és YFP-LIP1-NLS fứziós fehérjék teljes mértékben képesek voltak helyreállituni a rôvid periódusú fenotipust, mig az YFP-LIPI-NES esetében komplementáció nem lâthatỏ.

A cirkadián óra szabályozásában betöltött szerepének ellátásához a LIP1 fehérje jelentős részének sejtmagi elhelyezkedése elengedhetetlen. Ez a megfigyelés arra enged következtetni, hogy a LIP1 cirkadián órában betöltött szerepe különválasztható a fejlődésben, endoreduplikációban, stressztoleranciában, illetve fotomorfogenezisben betöltött szerepétől.

\begin{tabular}{|c|c|c|}
\hline Vonal & Periódushosz (óra) & \pm SEM \\
\hline Col-0 & 29.95 & 0.28 \\
lipl-2 & 27.37 & 0.77 \\
YFP-LIP1 & 29.74 & 0.36 \\
YFP-LIP1-NLS & 29.33 & 0.7 \\
YFP-LIP1-NES & 27.42 & 0.31 \\
\hline
\end{tabular}

\section{7. táblázat.A cirkadiân fenotípus komplementálása LIP1 fú́ziós fehérjékkkel}

A nōvényeket 12:12 LD cikluson neveltük 7 napig, majd $5 \mu \mathrm{mol}$ foton $\mathrm{m}^{-2} \mathrm{~s}^{-1}$ intenzitású folyamatos vōrös fënybe helyeztük öket. A CCR2:LUC markergén ritmikus kifejezódését mértük. A periódushossz mérést a BRASS2 program segitségével végeztük. Az YFP-LIP1 és YFP-LIP1-NLS fủziók komplementálták a rōvid periódust, míg az YFP-LIP1-NES füzió nem. 


\section{A LIP1 szerepe a cirkadián óra szabályozásában}

\section{A kimeneti elemek időbeli mintázatának vizsgálata}

A cirkadián óra tanulmányozásának legáltalánosabb módja, ha valamely kimeneti elemének időbeli mintázatát figyeljük. A fó órakomponensek promotereit (CCA1, LHY, GI, PRR9) kimeneti elemként használva megvizsgáltuk, hogy a LIP1 hiánya milyen változást okoz. Korábbi vizsgálatokból már ismert volt, hogy a LIP1 hiányában rövid periódus figyelhetö meg a reggel kifejeződő CAB2 (CHLOROPHYLL A/B-BINDING 2) és az este kifejeződő CCR2 (COLD-AND CIRCADIAN REGULATED 2) általánosan használt kimeneti elemek esetében (Kevei és mtsai, 2007a). A promoterek működését a szentjánosbogár luciferáz enzim aktivitásának nyomonkövetésével vizsgáltuk in vivo. CCA1:LUC, LHY:LUC, GI:LUC, PRR9:LUC markergének kifejeződését teszteltük Col-0 és lip1-2 mutáns növényekben.

A markergének müködését gyenge vörös fényben követtük nyomon luminométerrel. A lip1-1 rövid periódusa ilyen körülmények között már szembetünő (Kevei és mtsai, 2007a). Minden markergén esetében a CCR2:LUC és CAB2:LUC markergéneknél már korábban leírt rövid periódust tapasztaltuk (8. táblázat). Ezek az eredmények azt is bizonyítják, hogy a LIP1 nem egy mellékszabályozókör része, mivel hiánya több különböző kimenetet is hasonló módon érint.

\begin{tabular}{|c|c|c|c|}
\hline Vonal & Kimenet & Periódushossz (óra) & \pm SEM \\
\hline Col-0 & CAB & 26.71 & 0.25 \\
lipl-2 & & 23.41 & 0.29 \\
\hline Col-0 & CCR2 & 27.01 & 0.51 \\
lipl-2 & & 25.42 & 0.32 \\
\hline Col-0 & CCAI & 26.71 & 0.54 \\
lipl-2 & & 23.88 & 0.65 \\
\hline Col-0 & LHY & 26.4 & 0.28 \\
lipl-2 & & 24.63 & 0.23 \\
\hline Col-0 & GI & 26.28 & 0.45 \\
lipl-2 & & 25.75 & 0.35 \\
\hline Col-0 & PRR & 26.78 & 0.46 \\
lipl-2 & & 23.98 & 0.45 \\
\hline
\end{tabular}

\section{8. táblázat. Óragének kífejezódésének mintázata lip1-2 mutánsban}

A nōvényeket 12:12 LD cikluson neveltünk 7 napig, majd $5 \mu \mathrm{mol} \mathrm{foton} \mathrm{m}^{-2} \mathrm{~s}^{-1}$ intenzitású folyamatos vörös fênybe helyeztük ôket. A felltūntetett markergének ritmikus kifejezõdését mértük. A periodushossz mérést a BRASS2 program segítségével végeztük. Minden kimeneti gén esetében a periódus a lip 1-2 mutánsban rõvidebb volt mint a vad típusban. 


\section{RNS szintü vizsgálatok}

A jelenlegi modell szerint a növényi cirkadián óra az óragének transzkripcióján és az mRNS molekulák transzlációján alapuló visszacsatolási körökből épül fel. Az elmélet szerint az óragének mRNS szintjének változása szükséges a ritmikus mintázat létrehozásához (McWatters és Devlin, 2011). Az mRNS szint változásának ezek szerint hatással kellene lennie a periódusra és a beállíthatóságra is. Számos olyan kísérleti eredmény létezik azonban, amelyek szerint az mRNS szintü szabályozás nem lényeges a ritmus létrehozása szempontjából, hanem csak kiegészítő szerepe van (Harmer és Kay, 2005). Egyre több olyan óraelemet azonosítanak, amelyek nem a transzkripció szintjén befolyásolják az óra müködését (Kim és mtsai, 2007; Martin-Tryon és Kay, 2008).

A jelenlegi óramodell szerint ha az egyik hurkot elrontjuk egy komponens mutációjával, az nem állítja meg az órát, mert a többi hurok bizonyos mértékben képes azt továbbvinni (McWatters és Devlin, 2011). Az mRNS szintekben bekövetkező változások azonban jellemzőek lehetnek egy-egy hurokra, így egy elrontott génről meg lehet mondani, hogy melyik hurok müködésére van hatással. Annak kiderítésére, hogy milyen hatással van a LIP1 a központi óraelemek mRNS mintázatára, megvizsgáltuk a reggeli $C C A 1$ és $P R R 9$, valamint az esti TOC1 és GI gének időbeli kifejeződését lip1-2 mutáns háttérben. A CCA1, PRR9, TOC1 és a GI mRNS szintjét 12 óra sötét/12 óra gyenge fehér fény $\left(5 \mu \mathrm{mol}\right.$ foton $\left.\mathrm{m}^{-2} \mathrm{~s}^{-1}\right)$ cikluson nevelt csíranövényekben mértük valós idejü PCR segítségével. A kifejeződési szint maximuma jelentősen lecsökkent a CCA1 és TOC1 gének esetében a lip1-2 mutánsban (23. ábra A és B). A GI és a $P R R 9$ gének kifejeződésének mintázata nem változott számottevően a mutánsban a vad típushoz képest (23. ábra C és D). A lip1 mutáció a fenntiek alapján negatív hatással lehet a TOC1 transzkripciójára, ami viszont a CCA1 transzkripciót serkentené, ez magyarázza, hogy a lip1-2 mutánsban mindkettő csökkent kifejeződést mutat. 
A
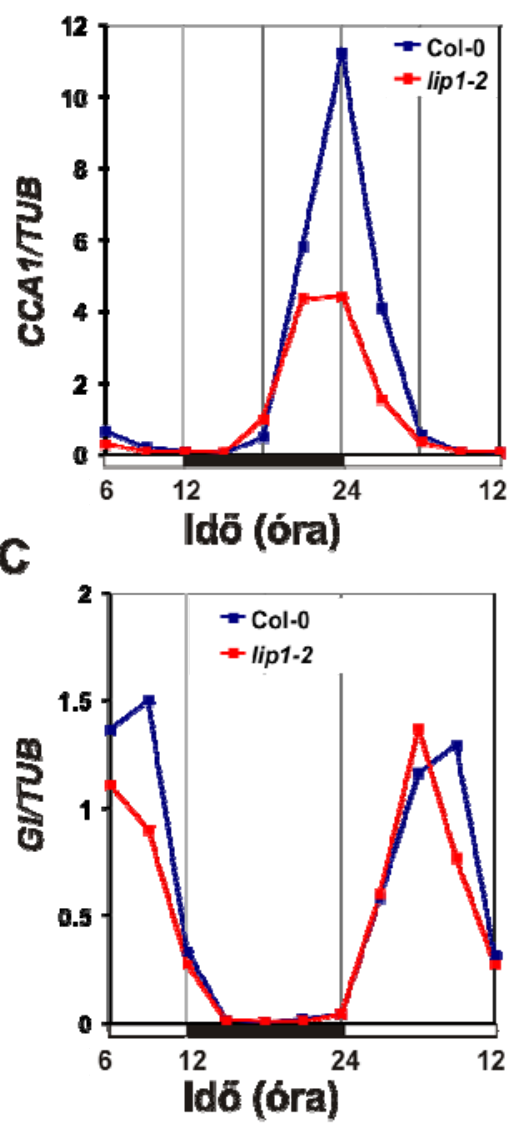

B

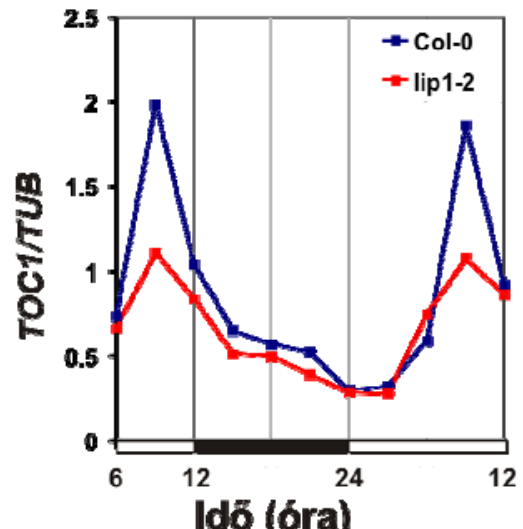

D

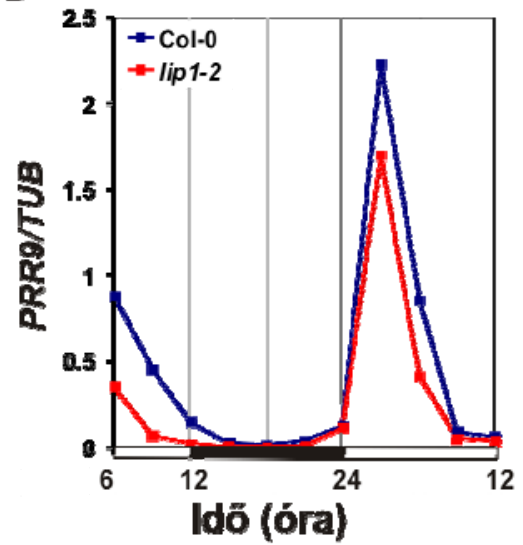

23. álbra. A kō̉zponti óragének mRNS szintjének idob̉heli változása diurnảlis körüllmények közzött

Anövényeket 12 óra sōtét/12 óra gyenge fehér fény ( $5 \mu \mathrm{mol}$ foton $\left.\mathrm{m}^{-2} \mathrm{~s}^{-1}\right)$ cikluson neveltük 9 napig, majd 3 óránként mintát vettünk be[ơlük 30 órán keresztül, amibő] ōssz-RNS-t tisztítottunk. A kōzponti óragénekmRNS-szintjét valós idejú PCR segítségével határoztuk meg, az értékeket a TUBULIN mRNS szintjęhez viszonyitva ábrázoltuk. Az $\mathrm{x}$ tengelyen a fehér sávok a nappalt, a fekete sáv a as̆̉tétet jelöli, 0-24 óra egy fẻny/sōtét ciklus.

(A) CCAI (reggeli gén), (B) TOCI (esti gén), (C) GI (esti gén), (D) PRR (reggeli gén) géneket vizsgáltuk.

A maximális kitérés csōkkenése tapasztalható a $C C A I$ és $T O C I$ gének esetében. Ez arra utal, hogy a vizsgált

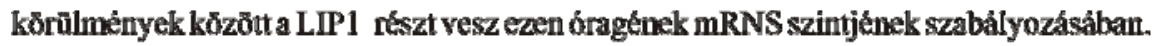

\section{Episztatikus génkölcsönhatások vizsgálata}

A következő kísérletsorozatban gének közötti kölcsönhatásokat (episztatikus hatásokat) vizsgáltunk a LIPl és központi óragének között, hogy többet tudjunk meg arról, mely órakomponenseken keresztül befolyásolja a LIP1 a cirkadián óra müködését. A vizsgálatokhoz a CCA1, GI, TOC1, PRR9, PRR5 óragéneket választottuk ki és a ccal-1, gi, toc1-4, prr9-1 és prr5-1 Columbia-0 hátterü mutánsokat használtuk fel, hogy kétszeres mutánsokat hozzunk létre. A növényeket 12:12 LD cikluson neveltük 7 napig, majd lumineszcencia méréseket végeztünk a CCR2:LUC markergént használva (kivéve a toc1-4 esetében, ahol a CAB2:LUC markert használtuk). Különböző monokromatikus fényforrásokat és különböző fényintenzitásokat alkalmaztunk, hogy olyan optimális fénykörülmények között tudjunk vizsgálódni, ahol mindkét mutáció fenotípusa megbízhatóan érvényesül. 

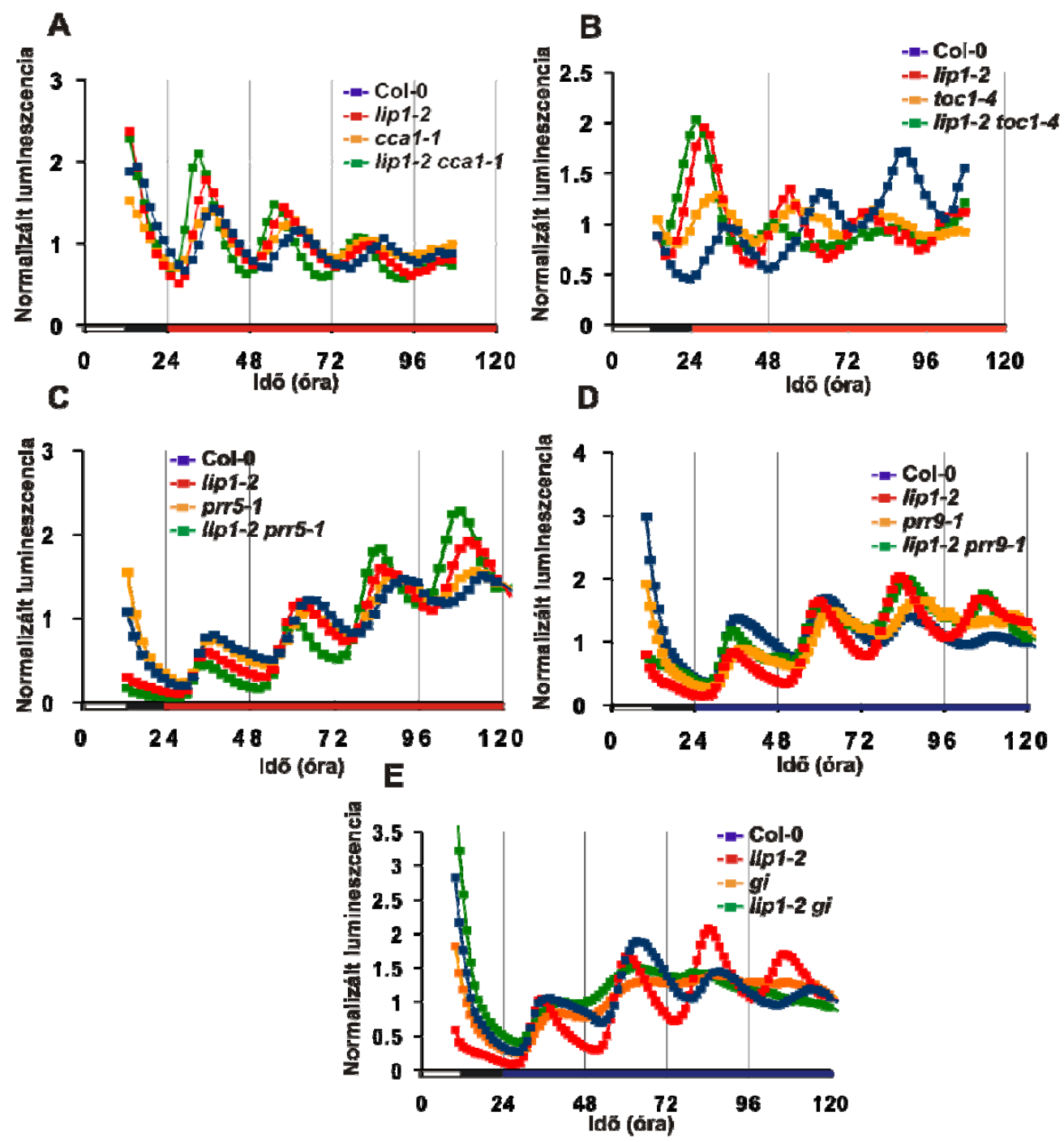

24. ábra.Jelzōgének kifejezôdési mintázata lippl-2 és óragén kétszeres mutánsokban

Anövényeket 12:12 LD cikluson neveltük 7 napig, majd

(A, C) folyamatos vörös fénybe $\left(16 \mu \mathrm{mol}\right.$ foton $\left.\mathrm{m}^{-2} \mathrm{~s}^{-1}\right)$

(D, E) folyamatos kék fénybe $\left(10 \mu \mathrm{mol}\right.$ foton $\left.\mathrm{m}^{-2} \mathrm{~s}^{-1}\right)$

(B) folyamatos gyenge vörös fênybe (1 $\mu \mathrm{mol}$ foton $\left.\mathrm{m}^{-2} \mathrm{~s}^{-1}\right)$ helyeztïk öket. A markergènek müködését 4 napig követüïk nyomon Juminométerrel.

(A, C, D, E) CCR2:LUC markergéntés (B) CAB:LUC markergént hasanáttunk.A lipl-2 mutációt (A) ceal-1, (B) tocl-4, (C) prrs-1, (D) prr9-1 és (E) $g i$ mutációkkal kombináltuk. A kêt mutició által okoztott hatás egyedül a lipl-2 $g i$ duplamutónshan nem adódoit össze, ebbð̋l arra következtethetünk, hogy a LIPI a GI órakomponensen keresztül hat a cirkadiân óra mủködésère.

A ccal-1 mutáció rövid periódust okoz 35-40 $\mu \mathrm{mol}$ foton $\mathrm{m}^{-2} \mathrm{~s}^{-1}$ vörös fényben (Alabadí és mtsai, 2002). A lip1-2 mutáció okozta periódus rövidülés tudjuk, hogy gyenge vörös fényben erőteljesebb, mint erős vörösben, ezért olyan tartományt kellett választanunk ahol még mindkét mutáció okozta periódus rövidülés megbízhatóan mérhető. A kísérletet $16 \mu \mathrm{mol}$ foton $\mathrm{m}^{-2} \mathrm{~s}^{-1}$ vörös fényben végeztük. A dupla mutáns esetében azt tapasztaltuk, hogy a periódus rövidebb, mint bármelyik egyszeres mutáns esetében, vagyis a két mutáció hatása 
összeadódott a kétszeres mutánsban, ami arra enged következtetni, hogy a két mutáció egymástól függetlenül fejti ki hatását (24. ábra A és 9. táblázat). A prr5-1 mutáció körülbelül 1 órás periódus rövidülést okoz $15 \mu \mathrm{mol}$ foton $\mathrm{m}^{-2} \mathrm{~s}^{-1}$ vörös fényben (Eriksson és mtsai, 2003). A dupla mutáns vizsgálatához ebben az esetben is $16 \mu \mathrm{mol}$ foton $\mathrm{m}^{-2} \mathrm{~s}^{-1}$ vörös fényt alkalmaztunk, és a génkölcsönhatásról ugyanazt a következtetést tudtuk levonni, mint a ccal1 esetében (24. ábra C és 9. táblázat).

A prr9-1 mutánsok vizsgálatakor a vörös fényt nem tudtuk alkalmazni, mert a prr9 mutáció által okozott hosszú periódusú fenotípus nem tünt szignifikánsnak ilyen körülmények között. A kétszeres mutánsok vizsgálatára alkalmasabbnak bizonyult $10 \mu \mathrm{mol}$ foton $\mathrm{m}^{-2} \mathrm{~s}^{-1}$ kék fényt használnunk. Ilyen körülmények között a prr9-1 által okozott enyhén hosszú periódus erőteljesebb, mint vörös fényben (Erikkson és mtsai, 2003), valamint a lip1-2 rövid periódusa is jól mérhető. A dupla mutáns kombináció esetében köztes fenotípust tapasztaltunk, a periódus hosszabb volt a lip1-2 mutánsénál viszont rövidebb a prr9-1 egyszeres mutánsénál (24. ábra D , 9. táblázat). Vagyis a mérések alapján a LIP1 nem ezen a komponensen keresztül hat az órára.

A toc 1-4 mutáns esetében gyenge vörös fényben (1-10 $\mu \mathrm{mol}$ foton $\left.\mathrm{m}^{-2} \mathrm{~s}^{-1}\right)$ rövid periódust figyeltek meg (Somers és mtsai, 1998b). A mérést $5 \mu \mathrm{mol}$ foton $\mathrm{m}^{-2} \mathrm{~s}^{-1}$ vörös fényben végeztük, ahol mind a két mutáció által okozott rövid periódus mérhető. Szerencsésebbnek bizonyult a gyenge fényviszonyok miatt a $C A B 2$ promótert használnuk kimeneti elemként. A dupla mutánsban mindkét egyszeres mutánsnál rövidebb periódust tapasztaltunk, vagyis a két mutáció hatása összegződött, ami ismételten arra utal, hogy a LIP1 nem ezen az órakomponensen keresztül fejti ki a hatását (24. ábra B és 9. táblázat).

A gi mutáns esetében olyan intenzitású kék fényt $\left(10 \mu \mathrm{mol}\right.$ foton $\left.\mathrm{m}^{-2} \mathrm{~s}^{-1}\right)$ alkalmaztunk (Martin-Tryon és mtsai, 2007), ahol mérhető volt a gi által okozott rövid periódus és amplitudó csökkenés, valamint még a lip-2 rövid periódusa is. A kétszeres mutánsban a két mutáció által okozott rövid periódus nem adódott össze, a gi egyszeres mutánséhoz hasonlított periódus, valamint a gi által okozott jellegzetes amplitudó csökkenés is tisztán kivehető volt (24. ábra E és 9. táblázat). Ezen mérések alapján arra következtethetünk, hogy a GI egy olyan órakomponens, amin keresztül a LIP1 befolyással bír a cirkadián órára. Eközött a két gén között episztatikus kölcsönhatás figyelhető meg. Az episztatikus gén a GI, amelynek funkcióvesztése nem engedi érvényre jutni a másik gén, a LIPl (hiposztatikus gén) hatását a fenotípusban. 


\begin{tabular}{|c|c|c|c|}
\hline Vongl & Períodushiossz (óra) & \pm SEM & Fényviszonyok \\
\hline Col-0 & 27.4 & 0.38 & vörös \\
lipl-2 & 25.48 & 0.54 & \\
ccal-1 & 26.79 & 0.65 & \\
lipl-2 ccal-1 & 24.5 & 0.18 & \\
\hline \hline Col-0 & 27.76 & 0.52 & gyenge vörös \\
lipl-2 & 25.4 & 0.26 & \\
tocl-4 & 26.28 & 0.38 & \\
lipl-2 tocl-4 & 24.86 & 0.41 & \\
\hline \hline Col-0 & 26.27 & 0.46 & vörös \\
lipl-2 & 24.3 & 0.69 & \\
pmr $1-1$ & 24.6 & 0.61 & \\
lipl-2 prr5-1 & 23.5 & 0.20 & \\
\hline \hline Col-0 & 26.05 & 0.66 & kék \\
lipl-2 & 24.22 & 0.19 & \\
prr9-1 & 28.2 & 0.62 & \\
lipl-2 prr9-1 & 27.2 & 0.24 & \\
\hline \hline Col-0 & 26.71 & 0.25 & kék \\
lipl-2 & 23.41 & 0.29 & \\
gi & 24.91 & 0.23 & \\
lipl-2 gi & 24.72 & 0.51 & \\
\hline
\end{tabular}

\section{9. táblázat. Periódushossz analízise Lip1-2 és óragén kétszeres mutánsokban}

A nōvényeket 12:12 LD ciklusokon neveltuik 7 napig majd humineszcencia méréseket végeztünk a CCR2:LUC markergént használva (kivéve a toc 1-4, abol a CAB2:LUC markert használtuk), a feltūntetett monokromatikus fényforrásokat használva. A perídushossz értékek jól mutatják, hogy a két mutáció okozta változás a lipl-2 gi dupla mutáns esetében nem adódott össze,

További vizsgálatokat is végeztünk a lip1-2 gi dupla mutánssal. A fő szempontunk az volt, hogy találunk-e olyat a LIP1 pleiotróp funkciói között, ami összekötő elem lehet a cirkadián órával a GI-n keresztül. Bár az elsődleges eredmények (a kompartmentalizáció szükségessége a cirkadián órában betöltött szerep ellátásához)azt mutatták, hogy a LIP1 a cirkadián és az egyéb funkciók szabályozásában eltérő módon vesz részt. A lip1-2 gi dupla mutáns esetében megvizsgáltuk hogyan változik a hipokotil hossza vörös fényben, mivel azt tudjuk, hogy a fotomorfogenezis szabályozásában a cirkadián óra és azon belül a GI is részt vesz (MartinTryon és mtsai, 2007). Col-0, lip1-2, gi és lip1-2 gi csíranövényeket különböző intenzitású monokromatikus vörös fényen neveltük 4 napig, majd a növények szik alatti szárának hosszát mértük (25. ábra A). Azt tapasztaltuk, hogy a vártnak megfelelően a gi mutánsok hipokotilja hosszabb volt, a lip1-2 mutánsoké pedig rövidebb, mint a vad típusé. A lip1-2 gi dupla mutáns esetében a hipokotil hossza a gi egyszeres mutánséval egyezett meg. Vagyis ezen fenotípus esetén is a GI episztatikus a LIPl-gyel szemben.

Megvizsgáltuk továbbá a sóstressz türési képességét is a lip1-2 gi dupla mutánsoknak, mivel sok cirkadián óra komponensről tudott, hogy szerepet játszik különféle stressz-válaszok szabályozásában. Az egyszeres gi mutáns esetében azt tapasztaltuk, hogy sótürő képessége a 
vad típuséhoz hasonló. A dupla mutáns esetében pedig a lipl mutáció okozta érzékenység nem érvényesült, a sótürő képessége a vad típuséhoz, illetve az egyszeres gi mutánséhoz volt hasonló (25. ábra B).

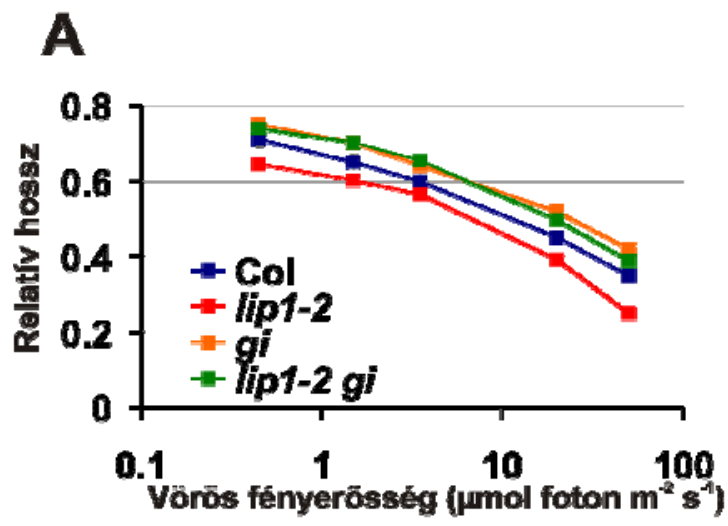

25. ábra. A lịp1-2 gi dupla mutáns fotomorfogenikus vảlasza a gĩ egyszeres mutảnsủhaz hasonlá és nem érzékeny a tápkäzzeg sótartalmára és

(A) A esíranōvényeket folyamatos vōrōs fẻnyen neveltük a megadott fenyintenzitasokon 4 napig, majd a szik alatti szár hasszát mértūk. Az értékeket sōtétben nevelt, azonos konú nôvények szárảnak hosszához viszonyitottuk. $\mathrm{Az}$ fgy kspott értéket a fênyintenzitás függvényében, Iogaritmusos skálán ábrizoltuk. A hibahatírokat standard hibaként adtuk meg (SE), a mintaszám 28-32 volt mérćsi pontonkćnt. A đuuplamutánsban a gi esyszeres mutáns fenotipusa érvényesüll.

(B ) A csiranōvényeket 12:12 LD cikluson neveltuik 14 napig a feltüntelett só koncentrációt tartalmazó táplemezeken. A lipl-2 gi duplamutáns sôtưrō kêpessége a gi mutánséval megegyezō.
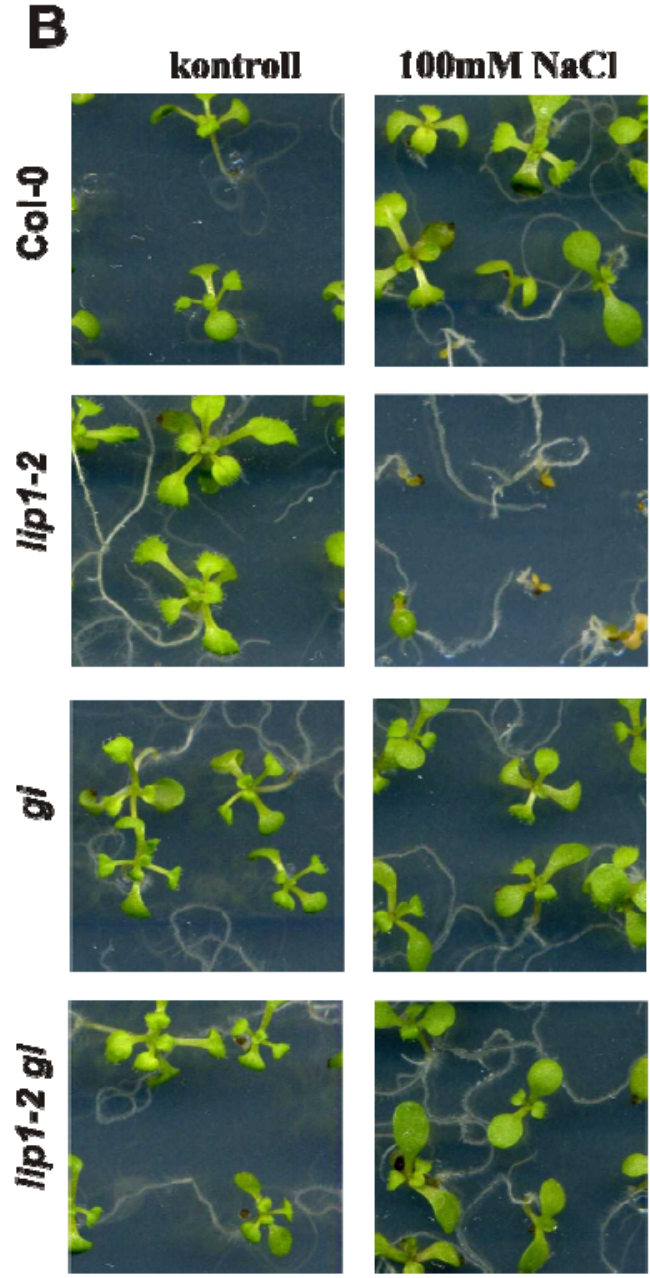


\section{AZ EREDMÉNYEK ÉRTELMEZÉSE}

\section{A LIP1 pleiotróp funkcióinak vizsgálata}

A lip1-1 mutánst egy mutáns-szürés során azonosítottuk (Kevei és mtsai, 2007a). A mutáció a szabadon futó periódus rövidülését okozza gyenge intenzitású vörös fényben, valamint a vörös és kék fényre adott fotomorfogenikus válaszok is sérülnek benne. A lip1-1 és a lip1-2 mutánsok számos egyéb pleiotróp fenotípussal is rendelkeznek. Munkánk során többek között ezeket a fenotípusokat vizsgáltuk. Megállapítottuk, hogy a LIP1-nek fontos szerepe van az endoreduplikáció fény általi gátlásának szabályozásában, valamint az abiotikus stressz tolerálásában.

Az előző fejezetben sok esetben szükséges volt a további kísérletek bevezetéséhez, és a kísérletek értelmezéséhez az egyes alfejezetekben konklúziót levonni. Így ebben a fejezetben a kapott eredmények összefoglalására törekszem, részletesebben tárgyalva azokat a szempontokat amelyekre az eredmények részben nem tértem ki.

\section{A LIP1 az endoreduplikáció szabályozásában fényfüggő módon vesz részt}

Korábban kimutatták, hogy a fitokróm A és fitokróm B fotoreceptorok által érzékelt vörös és távoli vörös fény az endoreduplikáció utolsó ciklusát gátolja Arabidopsis hipokotil börszöveti sejtjeiben, azonban a kék fény hatását még nem egyértelmü, hogy melyik fotoreceptor szabályozza (Gendreau és mtsai, 1998). A lipl mutáns csíranövényekben a kromatintartalom megnő fehér, vörös és kék fényben, sötétben azonban nem (10. és 11. ábra). Ez arra utal, hogy az endoreduplikáció fény által szabályozott formája szenved zavart a lip1 mutánsban. A vörös és kék fény által szabályozott ploidia mintázat genetikai analízise a fitokróm B és a kriptokróm 12 episztatikus hatását mutatta ki a LIP1 felett (11. ábra). Ezek szerint a LIP1 a fitokróm B és a kriptokróm 1-2 által szabályozott útvonalakon keresztül vesz részt az endoreduplikáció vörös és kék fény általi gátlásában. Genevestigator (https://www.genevestigator.com/gv/) és e-FP Browser (http://bar.utoronto.ca/efp/cgibin/efpWeb.cgi) adatok alapján (2012. június) a LIPl transzkripciója nem korlátozódik az osztódásban levő sejtekre. Ezért feltételezhető, hogy elsősorban az endoreduplikációs ciklus terminálásában lehet szerepe és nem az endoreduplikációs ciklusba való belépésért felel. Az endociklus terminációs lépéseiről azonban még hiányosak az ismeretek.

\section{A LIP1 fitokróm B és kriptokróm 1-2 függő módon szabályozza a fotomorfogenezist}

A lip1-1 mutáns növényekben a szik alatti szár hossza vörös és kék fényben megváltozik, a távoli vörös fénytől függő jelátviteli út azonban érintetlen. A lip1 mutáns vörös fényben 
tapasztalható fotomorfogenikus fenotípusa a fitokróm B-től, valamint a kék fényben a kriptokróm 1 és kriptokróm 2 fotoreceptoroktól függ.

A magasabb ploidia szinttel rendelkező sejtek általában nagyobbak vagy megnyúltak a normál kromatin mennyiséggel rendelkező sejtekhez képest. Ezért az endoreduplikációnak feltehetőleg szerepe van a szik alatti szár megnyúlásában. A lipl mutánsok szik alatti szára rövidebb, mint a vad típusé folyamatos vörös, illetve kék fényben. Ez arra utal, hogy a fotomorfogenikus fenotípust nem az endoreduplikáció gátlásának megszűnése okozza. Mindkét fenotípus megfigyelhető vörös és kék fényben, de távoli vörösben nem, valamint mindkét fenotípus függ a fitokróm B-től és a kriptokróm 1-2-től egyaránt. Ebből arra következtethetünk, hogy a LIP1 a fitokróm B és kriptokróm 1-2 által szabályozott jelátviteli útvonal egy olyan közös pontján helyezkedik el, ahol még a szik alatti szár megnyúlásáért és az endoreduplikációért felelős útvonalak nem váltak szét.

LIP1 fehérje hiányában a növények érzékenysége megnő az ozmotikus stresszel szemben

A lip1 mutáns növények rosszabbul fejlődnek magas $\mathrm{NaCl}$ tartalmú táptalajon, mint a vad típusú növények (13. ábra). Nemcsak a fejlődés, hanem a csírázási képesség (14. ábra) és a gyökér növekedése (15. ábra) is zavart szenved. A lip1 mutánsban ozmotikus stressz hatására az ABA-függő és -független gének a vad típuséhoz hasonlóan indukálódnak (16. ábra). Ez alapján feltételezhető, hogy a LIP1 hiányában nem a stressz érzékelése, a szignalizációs kaszkád, vagy a jelátviteli utak transzkripciójának aktiválása sérül.

A sóérzékeny fenotípus nem hozható kapcsolatba az endoreduplikációban bekövetkező változásokkal, mivel a mutáns növények olyan körülmények között is érzékenyek sóra (folyamatos sötétben), ahol a ploidia fenotípus nem érvényesül (14. ábra). A sóstressz nem befolyásolta a LIP1 hiányában mérhető periódushossz változást sem (5. táblázat).

A LIP1 szerepe feltehetőleg a cirkadián óra és bizonyos stressz folyamatok közötti kapcsolat biztosítása. A lip1 mutáns növények általában is fokozott érzékenységet mutatnak a tápközeg magas ion és ozmotikum tartalmára valamint a hőmérséklet stresszre (17. ábra).

Kis GTP-kötő fehérjék szerepe a stressz-válaszokban, a ploidia szint meghatározásában és a sejtalak kialakításában

A hosszan fennálló stresszhatás lassú adaptációs folyamatokat indít be, amik óvják a növényt a károsodástól. Ilyen folyamatok például a sztómanyitás serkentése, valamint ozmolitok, antioxidánsok és másodlagos anyagcseretermékek akkumulálódása. Elképzelhető, hogy a LIP1 szerepe a stressz-válaszokban ezen késői folyamatok valamelyikének a sejtszintü 
szabályozása. Egyes kis GTP-kötő fehérjék emlősökben, élesztőben és növényekben is szerepet játszanak a reaktív oxigéngyökök termelödésének szabályozásában (Finkel, 2006), így a LIP1 szerepe sem zárható ki hasonló folyamatokban. Egy ROP típusú kis GTP-kötő fehérje, az OsRAC1, közvetlenül kölcsönhat egy NADPH oxidázzal rizsben, így szabályozva a reaktív oxigéngyökök képződését (Wong és mtsai, 2007). Az OsRAC1, és Arabidopsisban található homológja a ROP2, egyaránt szerepet játszik biotikus és abiotikus stressz-válaszok, valamint az azokat kísérő apoptózis-szerü sejthalál szabályozásában (Ono és mtsai, 2001; Park és mtsai, 2004). A fokozott stresszérzékenység mellett a lip1-2 mutánsban is megfigyelhető sejtelhalás, azonban itt csak a sziklevelek bőrszöveti sejtjeire korlátozódik a fejlődés korai szakaszában (8. ábra), míg az OsRAC1 hiányában az igazi leveleken jelennek meg nekrotikus léziók. Továbbá, a reaktív oxigéngyökök mennyiségének szabályozásában résztvevő kis GTP-ázok többnyire plazmamembrán-kötöttek, a LIP1 azonban a sejtmagban és a citoplazmában is egyaránt jelen van (18. ábra). A fokozott stresszérzékenység, amit a LIP1 hiánya okoz, a sejtmagban lokalizált LIP1 fehérjével is helyreállítható (20. ábra). A ploidia szint változása és a sejtelhalás következtében feltételezhető lenne, hogy a bőrszövet védő funkciója sérül a lip1 mutánsban, így a sóstressz hatását nem tudja megfelelően kivédeni. Azonban sötétben nevelt lipl mutáns növények számottevő ploidia és bőrszöveti sejtalak változás nélkül is érzékenyek tápközeg sótartalmának növekedésére. Mindez arra utal, hogy a sóérzékenységet a lipl mutáns esetében nem a sejtelhalás és a ploidia szám változása okozza.

A LIP1 a növényi kis GTP-ázok egy új és még nem teljesen jellemzett alcsaládjába tartozik. Jelenleg az egyetlen kis GTP-kötő fehérje, ami funkcionálisan kapcsolatba hozható a cirkadián óra szabályozásával (Kevei és mtsai, 2007a). Érdekes módon a ROP és a RAB alcsaládok egyes tagjai hasonló funkciókat szabályoznak, mint a LIP1. Például, egyes ROP GTP-ázok (ROP 2, 4 és 6) a börszöveti sejtek alakjának kialakításában vesznek részt a kortikális mikrofilamentumok és a mikrotubulus hálózat összerendeződésének és szerveződésének szabályozásán keresztül (Fu és mtsai, 2005; Fu és mtsai, 2009). Egy RAB típusú GTP-áz, az ARA6 a vezikuláris transzport szabályozásában vesz részt az endoszómák és a plazmamembrán között, valamint a sóstressz-tolerancia kialakításában van szerepe (Ebine és mtsai, 2011). Nemrégiben mutatták ki, hogy a ROP8 GTP-áz aktivitását a fitokrómok szabályozzák, és ezáltal a fényszabályozott gyökérnövekedésben van fontos szerepe (Shin és mtsai, 2010). Annak a molekuláris mechanizmusa azonban, ahogyan a kis GTP-kötő fehérjék által szabályozott folyamatok sejtszinten szerveződnek, még ismeretlen. 


\section{A lip1 mutáció okozta fenotípusok komplementálhatósága}

A cirkadián óra nem megfelelő müködése, azaz a periódus rövidülése sötétben nevelt lip1 mutáns növényekben is megfigyelhető (Kevei és mtsai, 2007a). Ilyen körülmények között a ploidia szint nem különbözik lipl és vad típusú növényekben. Továbbá, a sóérzékenység, a fotomorfogenikus fenotípus és a ploidia számbeli változás olyan körülmények között is megfigyelhető, ahol a mutánsnak nincs cirkadián fenotípusa (például erős vörös vagy fehér fényben) (Kevei és mtsai, 2007a). Ezek a tények arra utalnak, hogy a LIP1 cirkadián funkciója független egyéb funkcióitól. Eszerint a cirkadián óra megváltozott müködése nem a stressz, a ploidia vagy a fotomorfogenikus fenotípus következménye. Ezt a következtetést erősítik a komplementációs kísérletek eredményei is. A cirkadián fenotípus helyreállítható LIP1-YFP és LIP1-YFP-NLS fúziós fehérjékkel, azonban LIP1-YFP-NES fúziós fehérjével nem. Ez arra utal, hogy a cirkadián funkció betöltéséhez a LIP1 fehérjének a sejtmagban egy kritikus mennyiség felett kell jelenlennie. A cirkadián fenotípus teljes komplementálása miatt feltehető, hogy a LIP1 az óra müködését érintő citoplazmatikus folyamatokat nem szabályozza, de az órafehérjék sejtmagi importját befolyásolhatja. A többi fenotípus egyaránt komplementálható volt LIP1-YFP, LIP1-YFP-NLS és LIP1-YFP-NES fúziós fehérjékkel. Azonban fontos megjegyezni, hogy a NES és NLS motívumok ugyan nagymértékben megváltoztatják a LIP1 fehérje sejten belüli eloszlását, de nem korlátozzák annak jelenlétét kizárólagosan csak a sejtmagra, illetve csak a citoplazmára. Különösképpen igaz ez a NES motívumra, amely például nem gátolja meg a nukleáris importot, de a nukleáris exportot segíti. Ezáltal csökkenti a fúziós fehérje által a sejtmagban töltött időt. Nem zárható ki, hogy nagyon kis mennyiségű sejtmagi LIP1-YFP-NES fúziós fehérje elégséges lehet bizonyos funkciók, mint például az endoreduplikáció szabályozásához. Ez a mennyiség azonban nem elegendő a cirkadián funkció helyreállításához. A sóstressz, a fotomorfogenikus és az endoreduplikációs fenotípus esetében nem jelenthető ki egyértelműen, hogy a LIP1 megfelelő funkciói mely sejtalkotóhoz köthetőek.

\section{A LIP1 szerepe a növények fejlődésének korai szakaszában fontos}

A LIP1 fontos szerepet tölt be kedvezőtlen körülmények között a csírázás szabályozásában, alacsony fényintenzitás mellett a cirkadián óra beállításában, valamint a fiatal csíranövények morfológiájának kialakításában. Mindezek alapján a LIP1 a csíranövények fejlödésének fontos regulátora. Azonban kizárt, hogy a LIP1 összes funkciója a csíranövény állapotra korlátozódna, mivel kifejeződése a legtöbb szervben kimutatható kifejlett növényben is. Kifejlett lipl mutáns növényben a sejtalak és a ploidia fenotípus nem figyelhető meg, ami vagy a fejlődés során eltérő módon szabályozott és funkcionálisan a 
LIP1-gyel redundáns fehérjék jelenlétével magyarázható, vagy pedig a fejlődés különböző stádiumaiban jelenlevő eltérő kölcsönható partnerekkel. Azoknak a LIP1-gyel konformációfüggő módon kölcsönható fehérjéknek az azonosítása, melyek a LIP1 aktivitását szabályozzák, vagy éppen a LIP1 által szabályozódnak, kulcsfontosságú lehet a LIP1 különböző szignalizációs utakban betöltött szerepének a megismeréséhez.

\section{A LIP1 és a cirkadián óra kapesolata}

LIP1 deficiens növényekben a luciferáz riportergén vizsgálatok a markergénnél korábban megfigyelt rövid periódust mutatták. RNS szinten a CCA1 és TOCl esetében a maximális kifejeződésben csökkenést tapasztaltunk a vizsgált körülmények között. Az óragének mutációját a lip1 mutációval kombinálva sikerült kimutatnunk, hogy a LIP1 és a cirkadián óra között az összekötő elem a GI órakomponens. A GI episztatikus hatása azonban nemcsak a cirkadián fenotípus esetében érvényesül, ugyanígy megfigyelhető a sóérzékeny és a fotomorfogenikus fenotípusok esetében is.

A GI-ról nemrégiben mutatták ki, hogy szerepet játszik a sóstressz-tolerancia kialakításában (Kim és mtsai, 2013). A vizsgált gi-1 allélt hordozó mutáns toleránsnak bizonyult sóval szemben, ellentétben az általunk vizsgált gi vonallal, ami nem mutatta ezt a fenotípust a mi kísérleti rendszerünkben. A GI képes komplexet képezni az SOS2-vel, ami az SOS útvonal egyik komponense, és nélkülözhetetlen a citoplazma megfelelő ionkoncentrációinak fenntartásához és a sóstressz tolerálásához (Zhu, 2002). A komplex gátolja az SOS2 aktivitását stresszmentes körülmények között, azonban sóstressz hatására az SOS2 felszabadul és aktiválja az SOS1 $\mathrm{Na}^{+} / \mathrm{H}^{+}$antiportert (Kim és mtsai, 2013). Eredményeik alapján érdemes lenne megvizsgálni, hogy fehérje szinten a LIP1-nek van-e hatása az SOS rendszer komponenseire, esetleg befolyásolja-e a GI-SOS2 komplex kialakulását. Mi az SOS2-t transzkripciós szinten vizsgáltuk lip1 mutánsban és nem tapasztaltunk változást LIP1 hiányában.

Azt, hogy a LIP1 és a GI között milyen jellegü kapcsolat van, nem tudtuk bizonyítani, a LIP1 nem a transzkripció szintjén van hatással a GI-ra. Viszont a GI pozitívan szabályozza a TOC1 gén kifejeződését, ami szintén pozitív hatással van a CCA1 transzkripcióra. Ezért feltételezhető, hogy a lip1 mutánsban tapasztalt CCA1 és TOC1 mRNS szint csökkenés a LIP1 és GI kölcsönhatásának következménye. A ccal és a tocl mutánsok egyaránt rövid periódust mutatnak (Somers és mtsai, 1998b; Alabadí és mtsai, 2002). Ezek alapján a lip1 mutánsban tapasztalt rövid periódus lehetséges, hogy a csökkent CCAl és TOC1 szint következménye. Ugyanakkor ennek ellentmond a CCA1 és LIP1 vagy TOC1 és LIP1 gének közti episztatikus kölcsönhatás hiánya. 


\section{KÖVETKEZTETÉSEK}

A dolgozatban leírt eredmények alapján az alábbi következtetések vonhatóak le:

1. A lip1 mutáns növényekben csíranövény stádiumban fényfüggő módon megváltozik a börszöveti sejtek alakja és mérete.

2. A lip1 mutáns növényekben a kromatintartalom megnő fehér, vörös és kék fényben, sötétben azonban nem. Az endoreduplikáció fény által szabályozott fitokróm $B$ és kriptokróm-függő formája szenved zavart a lip1 mutánsban. A lip1 mutánsok szik alatti szára rövidebb, mint a vad típusé folyamatos vörös, illetve kék fényben. A lip1 mutáns vörös fényben tapasztalható fotomorfogenikus fenotípusa főként a fitokróm B-töl, valamint a kék fényben a kriptokróm 1 és kriptokróm 2 fotoreceptoroktól függ.

3. A lip1 mutáns növények rosszabbul fejlödnek só tartalmú táptalajon, mint a vad típusú növények. Nemcsak a fejlődés, hanem a csírázási képesség és a gyökér növekedése is zavart szenved. LIP1 hiányában nem a stressz érzékelése, a szignalizációs kaszkád vagy a jelátviteli utak transzkripciójának aktiválása sérül. A sóérzékeny fenotípus független a cirkadián, a ploidia és a sejtalak fenotípusoktól. A lip1 mutáns növények fokozott érzékenységet mutatnak a tápközeg $\mathrm{CsCl}_{2}, \mathrm{LiCl}_{2}$ és mannitol tartalmára, valamint a hőmérséklet stresszre is.

4. A cirkadián fenotípus helyreállítható LIP1-YFP és LIP1-YFP-NLS fúziós fehérjékkel, azonban LIP1-YFP-NES fúziós fehérjével nem. A cirkadián funkció betöltéséhez a LIP1 sejtmagi elhelyezkedésére van szükség.

5. A többi fenotípus (sejtalak, ploidia, hipokotil, stressz) egyaránt komplementálható LIP1YFP, LIP1-YFP-NLS és LIP1-YFP-NES fúziós fehérjékkel. Ezekben az esetekben nem jelenthető ki egyértelmüen, hogy mely sejtalkotóhoz köthető az adott szabályozó szerepük.

6. LIP1 hiányában minden vizsgált kimeneti marker (CCR2, CAB, PRR9, CCA1, LHY, GI) esetében rövid periódus tapasztalható, míg RNS szinten a CCA1 és TOCl kifejeződésében a maximum értékek csökkenése figyelhető meg. A lip1 mutációt óragén mutációkkal kombinálva vizsgáltuk az episztatikus kölcsönhatás meglétét a gének között a cirkadián fenotípus tekintetében ( $p r r 9$, prr5, ccal, tocl, gi). A GI gén volt episztatikus a LIP1 felett, ez a kölcsönhatás további fenotípusok esetében is megfigyelhető volt (hipokotil, stressz). 


\section{SAJÁT KÖZLEMÉNYEK}

\section{A dolgozat alapját képező közlemény:}

Terecskei K*, Tóth R*, Gyula P, Kevei É, Bindics J, Coupland G, Nagy F, Kozma-Bognár L. 2013. The Circadian Clock-Associated Small GTPase LIGHT INSENSITIVE PERIOD1 Suppresses Light-Controlled Endoreplication and Affects Tolerance to Salt Stress in Arabidopsis. Plant Physiol 161(1):278-90.

\section{Egyéb közlemények:}

Kredics L*, Terecskei K*, Antal Z, Szekeres A, Hatvani L, Manczinger L, Vágvölgyi C. 2008. Purification and preliminary characterization of a cold-adapted extracellular proteinase from Trichoderma atroviride. Acta Biol Hung 59(2):259-68.

Sorokina O, Kapus A, Terecskei K, Dixon LE, Kozma-Bognár L, Nagy F, Millar AJ. 2009. A switchable light-input, light-output system modelled and constructed in yeast. J Biol Eng 3:15.

Palágyi A*, Terecskei K*, Ádám É, Kevei É, Kircher S, Mérai Z, Schaefer E, Nagy F, Kozma-Bognár L. 2010. Functional analysis of amino-terminal domains of the photoreceptor phytochrome B. Plant Physiol 153(4):1834-45.

Kircher S, Terecskei K, Wolf I, Sipos M, Ádám É. 2011. Phytochrome A-specific signaling in Arabidopsis thaliana. Plant Signal Behav 6(11):1714-9.

\footnotetext{
* megosztott első szerzők
} 


\section{IDÉZETT KÖZLEMÉNYEK}

Abe H, Urao T, Ito T, Seki M, Shinozaki K, Yamaguchi-Shinozaki K. 2003. Arabidopsis AtMYC2 (bHLH) and AtMYB2 (MYB) function as transcriptional activators in abscisic acid signaling. Plant Cell 15(1):63-78.

Adams J, Kelso R, Cooley L. 2000. The kelch repeat superfamily of proteins: propellers of cell function. Trends Cell Biol 10(1):17-24.

Ahn SC, Baek BS, Oh T, Song CS, Chatterjee B. 2000. Rapid mini-scale plasmid isolation for DNA sequencing and restriction mapping. Biotechniques 29(3):466-8.

Alabadí D, Oyama T, Yanovsky MJ, Harmon FG, Más P, Kay SA. 2001. Reciprocal regulation between TOC1 and LHY/CCA1 within the Arabidopsis circadian clock. Science 293(5531):880-3.

Alabadí D, Yanovsky MJ, Más P, Harmer SL, Kay SA. 2002. Critical role for CCA1 and LHY in maintaining circadian rhythmicity in Arabidopsis. Curr Biol 12(9):757-61.

Aschoff J. 1979. Circadian rhythms: influences of internal and external factors on the period measured in constant conditions. Zeitschrift für Tierpsychologie 49(3):225-249.

Batelli G, Verslues PE, Agius F, Qiu Q, Fujii H, Pan S, Schumaker KS, Grillo S, Zhu JK. 2007. SOS2 promotes salt tolerance in part by interacting with the vacuolar $\mathrm{H}+-$ ATPase and upregulating its transport activity. Mol Cell Biol 27(22):7781-90.

Bell-Pedersen D, Cassone VM, Earnest DJ, Golden SS, Hardin PE, Thomas TL, Zoran MJ. 2005. Circadian rhythms from multiple oscillators: lessons from diverse organisms. Nat Rev Genet 6(7):544-56.

Ben-Naim O, Eshed R, Parnis A, Teper-Bamnolker P, Shalit A, Coupland G, Samach A, Lifschitz E. 2006. The CCAAT binding factor can mediate interactions between CONSTANS-like proteins and DNA. Plant J 46(3):462-76.

Berckmans B, Lammens T, Van Den Daele H, Magyar Z, Bögre L, De Veylder L. 2011. Light-dependent regulation of DEL1 is determined by the antagonistic action of E2Fb and E2Fc. Plant Physiol 157(3):1440-51.

Berken A, Thomas C, Wittinghofer A. 2005. A new family of RhoGEFs activates the Rop molecular switch in plants. Nature 436(7054):1176-80.

Boisnard-Lorig C, Colon-Carmona A, Bauch M, Hodge S, Doerner P, Bancharel E, Dumas C, Haseloff J, Berger F. 2001. Dynamic analyses of the expression of the HISTONE::YFP fusion protein in arabidopsis show that syncytial endosperm is divided in mitotic domains. Plant Cell 13(3):495-509.

Booij-James IS, Swegle WM, Edelman M, Mattoo AK. 2002. Phosphorylation of the D1 photosystem II reaction center protein is controlled by an endogenous circadian rhythm. Plant Physiol 130(4):2069-75.

Boss PK, Bastow RM, Mylne JS, Dean C. 2004. Multiple pathways in the decision to flower: enabling, promoting, and resetting. Plant Cell 16 Suppl:S18-31.

Boudolf V, Barrôco R, Engler JeA, Verkest A, Beeckman T, Naudts M, Inzé D, De Veylder L. 2004. B1-type cyclin-dependent kinases are essential for the formation of stomatal complexes in Arabidopsis thaliana. Plant Cell 16(4):945-55.

Cao S, Ye M, Jiang S. 2005. Involvement of GIGANTEA gene in the regulation of the cold stress response in Arabidopsis. Plant Cell Rep 24(11):683-90.

Cashmore AR, Jarillo JA, Wu YJ, Liu D. 1999. Cryptochromes: blue light receptors for plants and animals. Science 284(5415):760-5.

Castillon A, Shen H, Huq E. 2007. Phytochrome Interacting Factors: central players in phytochrome-mediated light signaling networks. Trends Plant Sci 12(11):514-21.

Chen ZJ. 2010. Molecular mechanisms of polyploidy and hybrid vigor. Trends Plant Sci 15(2):57-71.

Choi H, Hong J, Ha J, Kang J, Kim SY. 2000. ABFs, a family of ABA-responsive element binding factors. J Biol Chem 275(3):1723-30. 
Churchman ML, Brown ML, Kato N, Kirik V, Hülskamp M, Inzé D, De Veylder L, Walker JD, Zheng Z, Oppenheimer DG, Gwin T, Churchman J, Larkin CJ. 2006. SIAMESE, a plant-specific cell cycle regulator, controls endoreplication onset in Arabidopsis thaliana. Plant Cell 18(11):3145-57.

Ciereszko I, Kleczkowski LA. 2002. Effects of phosphate deficiency and sugars on expression of rab18 in Arabidopsis: hexokinase-dependent and okadaic acid-sensitive transduction of the sugar signal. Biochim Biophys Acta 1579(1):43-9.

Cloix C, Jenkins GI. 2008. Interaction of the Arabidopsis UV-B-specific signaling component UVR8 with chromatin. Mol Plant 1(1):118-28.

Clough SJ, Bent AF. 1998. Floral dip: a simplified method for Agrobacterium-mediated transformation of Arabidopsis thaliana. Plant J 16(6):735-43.

Cookson SJ, Granier C. 2006. A dynamic analysis of the shade-induced plasticity in Arabidopsis thaliana rosette leaf development reveals new components of the shadeadaptative response. Ann Bot 97(3):443-52.

Covington MF, Harmer SL. 2007. The circadian clock regulates auxin signaling and responses in Arabidopsis. PLoS Biol 5(8):e222.

Covington MF, Maloof JN, Straume M, Kay SA, Harmer SL. 2008. Global transcriptome analysis reveals circadian regulation of key pathways in plant growth and development. Genome Biol 9(8):R130.

D'Amato. 1964. Endopolyploidy as a factor in plant tissue development. Caryologia 17:4152

Daniel X, Sugano S, Tobin EM. 2004. CK2 phosphorylation of CCA1 is necessary for its circadian oscillator function in Arabidopsis. Proc Natl Acad Sci U S A 101(9):3292-7.

David KM, Armbruster U, Tama N, Putterill J. 2006. Arabidopsis GIGANTEA protein is post-transcriptionally regulated by light and dark. FEBS Lett 580(5):1193-7.

del Pozo JC, Boniotti MB, Gutierrez C. 2002. Arabidopsis E2Fc functions in cell division and is degraded by the ubiquitin-SCF(AtSKP2) pathway in response to light. Plant Cell 14(12):3057-71.

Demarsy E, Fankhauser C. 2009. Higher plants use LOV to perceive blue light. Curr Opin Plant Biol 12(1):69-74.

Devlin PF, Kay SA. 2000. Cryptochromes are required for phytochrome signaling to the circadian clock but not for rhythmicity. Plant Cell 12(12):2499-2510.

Ding Z, Doyle MR, Amasino RM, Davis SJ. 2007a. A complex genetic interaction between Arabidopsis thaliana TOC 1 and CCA1/LHY in driving the circadian clock and in output regulation. Genetics 176(3):1501-10.

Ding Z, Millar AJ, Davis AM, Davis SJ. 2007b. TIME FOR COFFEE encodes a nuclear regulator in the Arabidopsis thaliana circadian clock. Plant Cell 19(5):1522-36.

Dodd AN, Salathia N, Hall A, Kévei E, Tóth R, Nagy F, Hibberd JM, Millar AJ, Webb AA. 2005. Plant circadian clocks increase photosynthesis, growth, survival, and competitive advantage. Science 309(5734):630-3.

Dong MA, Farré EM, Thomashow MF. 2011. Circadian clock-associated 1 and late elongated hypocotyl regulate expression of the C-repeat binding factor (CBF) pathway in Arabidopsis. Proc Natl Acad Sci U S A 108(17):7241-6.

Dowson-Day MJ, Millar AJ. 1999. Circadian dysfunction causes aberrant hypocotyl elongation patterns in Arabidopsis. Plant J 17(1):63-71.

Doyle MR, Davis SJ, Bastow RM, McWatters HG, Kozma-Bognár L, Nagy F, Millar AJ, Amasino RM. 2002. The ELF4 gene controls circadian rhythms and flowering time in Arabidopsis thaliana. Nature 419(6902):74-7.

Dunlap JC. 1999. Molecular bases for circadian clocks. Cell 96(2):271-90. 
Ebine K, Fujimoto M, Okatani Y, Nishiyama T, Goh T, Ito E, Dainobu T, Nishitani A, Uemura T, Sato MH, Thordal-Christensen H, Tsutsumi N, Nakano A, Ueda T. 2011. A membrane trafficking pathway regulated by the plant-specific RAB GTPase ARA6. Nat Cell Biol 13(7):853-9.

Eimert K, Wang SM, Lue WI, Chen J. 1995. Monogenic Recessive Mutations Causing Both Late Floral Initiation and Excess Starch Accumulation in Arabidopsis. Plant Cell 7(10):1703-1712.

Eriksson ME, Hanano S, Southern MM, Hall A, Millar AJ. 2003. Response regulator homologues have complementary, light-dependent functions in the Arabidopsis circadian clock. Planta 218(1):159-62.

Farré EM, Kay SA. 2007. PRR7 protein levels are regulated by light and the circadian clock in Arabidopsis. Plant J 52(3):548-60.

Favory JJ, Stec A, Gruber H, Rizzini L, Oravecz A, Funk M, Albert A, Cloix C, Jenkins GI, Oakeley EJ, Steidlitz HK, Nagy F, Ulm R. 2009. Interaction of COP1 and UVR8 regulates UV-B-induced photomorphogenesis and stress acclimation in Arabidopsis. EMBO J 28(5):591-601.

Fehér B, Kozma-Bognár L, Kevei É, Hajdu A, Binkert M, Davis SJ, Schaefer E, Ulm R, Nagy F. 2011. Functional interaction of the circadian clock and UV RESISTANCE LOCUS 8-controlled UV-B signaling pathways in Arabidopsis thaliana. Plant J 67(1):37-48.

Finkel T. 2006. Intracellular redox regulation by the family of small GTPases. Antioxid Redox Signal 8(9-10):1857-63.

Fowler SG, Cook D, Thomashow MF. 2005. Low temperature induction of Arabidopsis CBF1, 2, and 3 is gated by the circadian clock. Plant Physiol 137(3):961-8.

Franklin KA, Larner VS, Whitelam GC. 2005. The signal transducing photoreceptors of plants. Int J Dev Biol 49(5-6):653-64.

Fu Y, Gu Y, Zheng Z, Wasteneys G, Yang Z. 2005. Arabidopsis interdigitating cell growth requires two antagonistic pathways with opposing action on cell morphogenesis. Cell 120(5):687-700.

$\mathrm{Fu} \mathrm{Y,} \mathrm{Xu} \mathrm{T,} \mathrm{Zhu} \mathrm{L,} \mathrm{Wen} \mathrm{M,} \mathrm{Yang} \mathrm{Z.} \mathrm{2009.} \mathrm{A} \mathrm{ROP} \mathrm{GTPase} \mathrm{signaling} \mathrm{pathway} \mathrm{controls}$ cortical microtubule ordering and cell expansion in Arabidopsis. Curr Biol 19(21):1827-32.

Fujiwara S, Wang L, Han L, Suh SS, Salomé PA, McClung CR, Somers DE. 2008. Posttranslational regulation of the Arabidopsis circadian clock through selective proteolysis and phosphorylation of pseudo-response regulator proteins. J Biol Chem 283(34):23073-83.

Fukushima A, Kusano M, Nakamichi N, Kobayashi M, Hayashi N, Sakakibara H, Mizuno T, Saito K. 2009. Impact of clock-associated Arabidopsis pseudo-response regulators in metabolic coordination. Proc Natl Acad Sci U S A 106(17):7251-6.

Furuya M, Schaefer E. 1996. Photoperception and signalling of induction reactions by different phytocnromes. Trends Plant Sci 1(9):301-307.

Galbraith DW, Harkins KR, Knapp S. 1991. Systemic Endopolyploidy in Arabidopsis thaliana. Plant Physiol 96(3):985-9.

Gekakis N, Staknis D, Nguyen HB, Davis FC, Wilsbacher LD, King DP, Takahashi JS, Weitz CJ. 1998. Role of the CLOCK protein in the mammalian circadian mechanism. Science 280(5369):1564-9.

Gendreau E, Traas J, Desnos T, Grandjean O, Caboche M, Höfte H. 1997. Cellular basis of hypocotyl growth in Arabidopsis thaliana. Plant Physiol 114(1):295-305.

Gendreau E, Höfte H, Grandjean O, Brown S, Traas J. 1998. Phytochrome controls the number of endoreduplication cycles in the Arabidopsis thaliana hypocotyl. Plant $\mathbf{J}$ 13(2):221-30. 
Gérard C, Goldbeter A. 2012. Entrainment of the mammalian cell cycle by the circadian clock: modeling two coupled cellular rhythms. PLoS Comput Biol 8(5):e1002516.

Geyer M, Wittinghofer A. 1997. GEFs, GAPs, GDIs and effectors: taking a closer (3D) look at the regulation of Ras-related GTP-binding proteins. Curr Opin Struct Biol 7(6):786-92.

Ghelis T, Dellis O, Jeannette E, Bardat F, Miginiac E, Sotta B. 2000. Abscisic acid plasmalemma perception triggers a calcium influx essential for RAB18 gene expression in Arabidopsis thaliana suspension cells. FEBS Lett 483(1):67-70.

Gorton HL, Williams WE, Assmann SM. 1993. Circadian Rhythms in Stomatal Responsiveness to Red and Blue Light. Plant Physiol 103(2):399-406.

Green RM, Tobin EM. 1999. Loss of the circadian clock-associated protein 1 in Arabidopsis results in altered clock-regulated gene expression. Proc Natl Acad Sci U S A 96(7):4176-9.

Green RM, Tingay S, Wang ZY, Tobin EM. 2002. Circadian rhythms confer a higher level of fitness to Arabidopsis plants. Plant Physiol 129(2):576-84.

Guimil S, Dunand C. 2007. Cell growth and differentiation in Arabidopsis epidermal cells. J Exp Bot 58(14):3829-40.

Gutierrez C. 2009. The Arabidopsis cell division cycle. Arabidopsis Book 7:e0120.

Hall A, Brown P. 2007. Monitoring circadian rhythms in Arabidopsis thaliana using luciferase reporter genes. Methods Mol Biol 362:143-52.

Harmer SL, Hogenesch JB, Straume M, Chang HS, Han B, Zhu T, Wang X, Kreps JA, Kay SA. 2000. Orchestrated transcription of key pathways in Arabidopsis by the circadian clock. Science 290(5499):2110-3.

Harmer SL, Kay SA. 2005. Positive and negative factors confer phase-specific circadian regulation of transcription in Arabidopsis. Plant Cell 17(7):1926-40.

Haydon MJ, Bell LJ, Webb AA. 2011. Interactions between plant circadian clocks and solute transport. J Exp Bot 62(7):2333-48.

Hazen SP, Borevitz JO, Harmon FG, Pruneda-Paz JL, Schultz TF, Yanovsky MJ, Liljegren SJ, Ecker JR, Kay SA. 2005a. Rapid array mapping of circadian clock and developmental mutations in Arabidopsis. Plant Physiol 138(2):990-7.

Hazen SP, Schultz TF, Pruneda-Paz JL, Borevitz JO, Ecker JR, Kay SA. 2005b. LUX ARRHYTHMO encodes a Myb domain protein essential for circadian rhythms. Proc Natl Acad Sci U S A 102(29):10387-92.

Huang T, Böhlenius H, Eriksson S, Parcy F, Nilsson O. 2005. The mRNA of the Arabidopsis gene FT moves from leaf to shoot apex and induces flowering. Science 309(5741):1694-6.

Hülskamp M, Misŕa S, Jürgens G. 1994. Genetic dissection of trichome cell development in Arabidopsis. Cell 76(3):555-66.

Huq E, Tepperman JM, Quail PH. 2000. GIGANTEA is a nuclear protein involved in phytochrome signaling in Arabidopsis. Proc Natl Acad Sci U S A 97(17):9789-94.

Imaizumi T, Schultz TF, Harmon FG, Ho LA, Kay SA. 2005. FKF1 F-box protein mediates cyclic degradation of a repressor of CONSTANS in Arabidopsis. Science 309(5732):293-7.

Inoue H, Nojima H, Okayama H. 1990. High efficiency transformation of Escherichia coli with plasmids. Gene 96(1):23-28.

Ito M, Araki S, Matsunaga S, Itoh T, Nishihama R, Machida Y, Doonan JH, Watanabe A. 2001. G2/M-phase-specific transcription during the plant cell cycle is mediated by cMyb-like transcription factors. Plant Cell 13(8):1891-905.

Ito S, Nakamichi N, Kiba T, Yamashino T, Mizuno T. 2007. Rhythmic and light-inducible appearance of clock-associated pseudo-response regulator protein PRR9 through programmed degradation in the dark in Arabidopsis thaliana. Plant Cell Physiol 48(11):1644-51. 
Jakoby M, Schnittger A. 2004. Cell cycle and differentiation. Curr Opin Plant Biol 7(6):6619.

Johnson CH. 1992. Phase Response Curves: What can they tell us about circadian clocks? Circadian clocks from cell to human. p. 209-246.

Jouve L, Gaspar T, Kevers C, Greppin H, Degli Agosti R. 1999. Involvement of indole-3acetic acid in the circadian growth of the first internode of Arabidopsis. Planta 209(1):136-42.

Kant P, Gordon M, Kant S, Zolla G, Davydov O, Heimer YM, Chalifa-Caspi V, Shaked R, Barak S. 2008. Functional-genomics-based identification of genes that regulate Arabidopsis responses to multiple abiotic stresses. Plant Cell Environ 31(6):697-714.

Kevei É, Gyula P, Fehér B, Tóth R, Viczián A, Kircher S, Rea D, Dorjgotov D, Schaefer E, Millar, Kozma-Bognár L, Nagy F. 2007a. Arabidopsis thaliana circadian clock is regulated by the small GTPase LIP1. Curr Biol 17(17):1456-64.

Kevei É, Schaefer E, Nagy F. 2007b. Light-regulated nucleo-cytoplasmic partitioning of phytochromes. J Exp Bot 58(12):3113-24.

Kiba T, Henriques R, Sakakibara H, Chua NH. 2007. Targeted degradation of PSEUDORESPONSE REGULATOR5 by an SCFZTL complex regulates clock function and photomorphogenesis in Arabidopsis thaliana. Plant Cell 19(8):2516-30.

Kidokoro S, Maruyama K, Nakashima K, Imura Y, Narusaka Y, Shinwari ZK, Osakabe Y, Fujita Y, Mizoi J, Shinozaki K, Yamaguchi-Shinozaki K. 2009. The phytochromeinteracting factor PIF7 negatively regulates DREB1 expression under circadian control in Arabidopsis. Plant Physiol 151(4):2046-57.

Kikis EA, Khanna R, Quail PH. 2005. ELF4 is a phytochrome-regulated component of a negative-feedback loop involving the central oscillator components CCA1 and LHY. Plant J 44(2):300-13.

Kim J, Kim Y, Yeom M, Kim JH, Nam HG. 2008. FIONA1 is essential for regulating period length in the Arabidopsis circadian clock. Plant Cell 20(2):307-19.

Kim JY, Song HR, Taylor BL, Carré IA. 2003. Light-regulated translation mediates gated induction of the Arabidopsis clock protein LHY. EMBO J 22(4):935-44.

Kim WY, Fujiwara S, Suh SS, Kim J, Kim Y, Han L, David K, Putterill J, Nam HG, Somers DE. 2007. ZEITLUPE is a circadian photoreceptor stabilized by GIGANTEA in blue light. Nature 449(7160):356-60.

Kim WY, Ali Z, Park HJ, Park SJ, Cha JY, Perez-Hormaeche J, Quintero FJ, Shin G, Kim MR, Qiang Z, Ning L, Park HC, Lee SY, Bressan RA, Pardo JM, Bohnert HJ, Yun DJ. 2013. Release of SOS2 kinase from sequestration with GIGANTEA determines salt tolerance in Arabidopsis. Nat Commun 4:1352.

Kipreos ET, Pagano M. 2000. The F-box protein family. Genome Biol 1(5):REVIEWS3002.

Kondorosi E, Kondorosi A. 2004. Endoreduplication and activation of the anaphasepromoting complex during symbiotic cell development. FEBS Lett 567(1):152-7.

Kuno N, Møller SG, Shinomura T, Xu X, Chua NH, Furuya M. 2003. The novel MYB protein EARLY-PHYTOCHROME-RESPONSIVE1 is a component of a slave circadian oscillator in Arabidopsis. Plant Cell 15(10):2476-88.

Kurepa J, Smalle J, Van Montagu M, Inzé D. 1998. Oxidative stress tolerance and longevity in Arabidopsis: the late-flowering mutant gigantea is tolerant to paraquat. Plant $\mathrm{J}$ 14(6):759-64.

Lechner E, Achard P, Vansiri A, Potuschak T, Genschik P. 2006. F-box proteins everywhere. Curr Opin Plant Biol 9(6):631-8.

Legnaioli T, Cuevas J, Mas P. 2009. TOC1 functions as a molecular switch connecting the circadian clock with plant responses to drought. EMBO J 28(23):3745-57.

Leipe DD, Wolf YI, Koonin EV, Aravind L. 2002. Classification and evolution of P-loop GTPases and related ATPases. J Mol Biol 317(1):41-72.

Lin C. 2002. Blue light receptors and signal transduction. Plant Cell 14 Suppl:S207-25. 
Lin C, Shalitin D. 2003. Cryptochrome structure and signal transduction. Annu Rev Plant Biol 54:469-96.

Liu LJ, Zhang YC, Li QH, Sang Y, Mao J, Lian HL, Wang L, Yang HQ. 2008. COP1mediated ubiquitination of CONSTANS is implicated in cryptochrome regulation of flowering in Arabidopsis. Plant Cell 20(2):292-306.

Locke JC, Southern MM, Kozma-Bognár L, Hibberd V, Brown PE, Turner MS, Millar AJ. 2005. Extension of a genetic network model by iterative experimentation and mathematical analysis. Mol Syst Biol 1:2005.0013.

Makino S, Kiba T, Imamura A, Hanaki N, Nakamura A, Suzuki T, Taniguchi M, Ueguchi C, Sugiyama T, Mizuno T. 2000. Genes encoding pseudo-response regulators: insight into His-to-Asp phosphorelay and circadian rhythm in Arabidopsis thaliana. Plant Cell Physiol 41(6):791-803.

Martin-Tryon EL, Kreps JA, Harmer SL. 2007. GIGANTEA acts in blue light signaling and has biochemically separable roles in circadian clock and flowering time regulation. Plant Physiol 143(1):473-86.

Martin-Tryon EL, Harmer SL. 2008. XAP5 CIRCADIAN TIMEKEEPER coordinates light signals for proper timing of photomorphogenesis and the circadian clock in Arabidopsis. Plant Cell 20(5):1244-59.

Más P, Kim WY, Somers DE, Kay SA. 2003. Targeted degradation of TOC1 by ZTL modulates circadian function in Arabidopsis thaliana. Nature 426(6966):567-70.

Más P. 2008. Circadian clock function in Arabidopsis thaliana: time beyond transcription. Trends Cell Biol 18(6):273-81.

Matsuo T, Yamaguchi S, Mitsui S, Emi A, Shimoda F, Okamura H. 2003. Control mechanism of the circadian clock for timing of cell division in vivo. Science 302(5643):255-9.

McClung CR. 2006. Plant circadian rhythms. Plant Cell 18(4):792-803.

McWatters HG, Bastow RM, Hall A, Millar AJ. 2000. The ELF3 zeitnehmer regulates light signalling to the circadian clock. Nature 408(6813):716-20.

McWatters HG, Kolmos E, Hall A, Doyle MR, Amasino RM, Gyula P, Nagy F, Millar AJ, Davis SJ. 2007. ELF4 is required for oscillatory properties of the circadian clock. Plant Physiol 144(1):391-401.

McWatters HG, Devlin PF. 2011. Timing in plants--a rhythmic arrangement. FEBS Lett 585(10):1474-84.

Messerli G, Partovi Nia V, Trevisan M, Kolbe A, Schauer N, Geigenberger P, Chen J, Davison AC, Fernie AR, Zeeman SC. 2007. Rapid classification of phenotypic mutants of Arabidopsis via metabolite fingerprinting. Plant Physiol 143(4):1484-92.

Michael TP, McClung CR. 2003. Enhancer trapping reveals widespread circadian clock transcriptional control in Arabidopsis. Plant Physiol 132(2):629-39.

Mikkelsen MD, Thomashow MF. 2009. A role for circadian evening elements in coldregulated gene expression in Arabidopsis. Plant J 60(2):328-39.

Millar AJ, Short SR, Chua NH, Kay SA. 1992. A novel circadian phenotype based on firefly luciferase expression in transgenic plants. Plant Cell 4(9):1075-87.

Millar AJ, Straume M, Chory J, Chua NH, Kay SA. 1995. The regulation of circadian period by phototransduction pathways in Arabidopsis. Science 267(5201):1163-1166.

Mizoguchi T, Wheatley K, Hanzawa Y, Wright L, Mizoguchi M, Song HR, Carré IA, Coupland G. 2002. LHY and CCA1 are partially redundant genes required to maintain circadian rhythms in Arabidopsis. Dev Cell 2(5):629-41.

Mizoguchi T, Wright L, Fujiwara S, Cremer F, Lee K, Onouchi H, Mouradov A, Fowler S, Kamada H, Putterill J, Coupland G. 2005. Distinct roles of GIGANTEA in promoting flowering and regulating circadian rhythms in Arabidopsis. Plant Cell 17(8):2255-70. 
Mockler TC, Guo H, Yang H, Duong H, Lin C. 1999. Antagonistic actions of Arabidopsis cryptochromes and phytochrome B in the regulation of floral induction. Development 126(10):2073-82.

Nagy F, Schaefer E. 2002. Phytochromes control photomorphogenesis by differentially regulated, interacting signaling pathways in higher plants. Annu Rev Plant Biol 53:329-55.

Nakamichi N, Kita M, Ito S, Yamashino T, Mizuno T. 2005. PSEUDO-RESPONSE REGULATORS, PRR9, PRR7 and PRR5, together play essential roles close to the circadian clock of Arabidopsis thaliana. Plant Cell Physiol 46(5):686-98.

Nakamichi N, Kusano M, Fukushima A, Kita M, Ito S, Yamashino T, Saito K, Sakakibara H, Mizuno T. 2009. Transcript profiling of an Arabidopsis PSEUDO RESPONSE REGULATOR arrhythmic triple mutant reveals a role for the circadian clock in cold stress response. Plant Cell Physiol 50(3):447-62.

Ni Z, Kim ED, Ha M, Lackey E, Liu J, Zhang Y, Sun Q, Chen ZJ. 2009. Altered circadian rhythms regulate growth vigour in hybrids and allopolyploids. Nature 457(7227):32731 .

Niinuma K, Someya N, Kimura M, Yamaguchi I, Hamamoto H. 2005. Circadian rhythm of circumnutation in inflorescence stems of Arabidopsis. Plant Cell Physiol 46(8):14237.

Nozue K, Covington MF, Duek PD, Lorrain S, Fankhauser C, Harmer SL, Maloof JN. 2007. Rhythmic growth explained by coincidence between internal and external cues. Nature 448(7151):358-61.

Ogura Y, Tokutomi S, Wada M, Kiyosue T. 2008. PAS/LOV proteins: A proposed new class of plant blue light receptor. Plant Signal Behav 3(11):966-8.

Ono E, Wong HL, Kawasaki T, Hasegawa M, Kodama O, Shimamoto K. 2001. Essential role of the small GTPase Rac in disease resistance of rice. Proc Natl Acad Sci U S A 98(2):759-64.

Paduch M, Jeleń F, Otlewski J. 2001. Structure of small G proteins and their regulators. Acta Biochim Pol 48(4):829-50.

Palágyi A, Terecskei K, Ádám E, Kevei É, Kircher S, Mérai Z, Schaefer E, Nagy F, KozmaBognár L. 2010. Functional analysis of amino-terminal domains of the photoreceptor phytochrome B. Plant Physiol 153(4):1834-45.

Panda S, Poirier GG, Kay SA. 2002. tej defines a role for poly(ADP-ribosyl)ation in establishing period length of the arabidopsis circadian oscillator. Dev Cell 3(1):51-61.

Para A, Farré EM, Imaizumi T, Pruneda-Paz JL, Harmon FG, Kay SA. 2007. PRR3 Is a vascular regulator of TOC1 stability in the Arabidopsis circadian clock. Plant Cell 19(11):3462-73.

Park DH, Somers DE, Kim YS, Choy YH, Lim HK, Soh MS, Kim HJ, Kay SA, Nam HG. 1999. Control of circadian rhythms and photoperiodic flowering by the Arabidopsis GIGANTEA gene. Science 285(5433):1579-82.

Park J, Gu Y, Lee Y, Yang Z. 2004. Phosphatidic acid induces leaf cell death in Arabidopsis by activating the Rho-related small G protein GTPase-mediated pathway of reactive oxygen species generation. Plant Physiol 134(1):129-36.

Perales M, Portolés S, Más P. 2006. The proteasome-dependent degradation of CKB4 is regulated by the Arabidopsis biological clock. Plant J 46(5):849-60.

Plautz JD, Straume M, Stanewsky R, Jamison CF, Brandes C, Dowse HB, Hall JC, Kay SA. 1997. Quantitative analysis of Drosophila period gene transcription in living animals. Journal of Biological Rhythms 12(3): 204-217.

Pope B, Kent HM. 1996. High efficiency 5 min transformation of Escherichia coli. Nucleic Acids Res 24(3):536-7.

Pruneda-Paz JL, Breton G, Para A, Kay SA. 2009. A functional genomics approach reveals CHE as a component of the Arabidopsis circadian clock. Science 323(5920):1481-5. 
Radziejwoski A, Vlieghe K, Lammens T, Berckmans B, Maes S, Jansen MA, Knappe C, Albert A, Seidlitz HK, Bahnweg G, Inzé D, De Veylder L. 2011. Atypical E2F activity coordinates PHR1 photolyase gene transcription with endoreduplication onset. EMBO J 30(2):355-63.

Reed JW, Nagpal P, Poole DS, Furuya M, Chory J. 1993. Mutations in the gene for the red/far-red light receptor phytochrome B alter cell elongation and physiological responses throughout Arabidopsis development. Plant Cell 5(2):147-57.

Reed JW, Nagatani A, Elich TD, Fagan M, Chory J. 1994. Phytochrome A and Phytochrome B Have Overlapping but Distinct Functions in Arabidopsis Development. Plant Physiol 104(4):1139-1149.

Rikin A, Dillwith JW, Bergman DK. 1993. Correlation between the Circadian Rhythm of Resistance to Extreme Temperatures and Changes in Fatty Acid Composition in Cotton Seedlings. Plant Physiol 101(1):31-36.

Rizzini L, Favory JJ, Cloix C, Faggionato D, O'Hara A, Kaiserli E, Baumeister R, Schaefer E, Nagy F, Jenkins GI, Ulm R. 2011. Perception of UV-B by the Arabidopsis UVR8 protein. Science 332(6025):103-6.

Roenneberg T, Merrow M. 2001. Circadian systems: different levels of complexity. Philos Trans R Soc Lond B Biol Sci 356(1415):1687-96.

Roodbarkelari F, Bramsiepe J, Weinl C, Marquardt S, Novák B, Jakoby MJ, Lechner E, Genschik P, Schnittger A. 2010. Cullin 4-ring finger-ligase plays a key role in the control of endoreplication cycles in Arabidopsis trichomes. Proc Natl Acad Sci U S A 107(34):15275-80.

Sabelli PA, Larkins BA. 2009. The contribution of cell cycle regulation to endosperm development. Sex Plant Reprod 22(4):207-19.

Sakuma Y, Liu Q, Dubouzet JG, Abe H, Shinozaki K, Yamaguchi-Shinozaki K. 2002. DNAbinding specificity of the ERF/AP2 domain of Arabidopsis DREBs, transcription factors involved in dehydration- and cold-inducible gene expression. Biochem Biophys Res Commun 290(3):998-1009.

Salomé PA, Xie Q, McClung CR. 2008. Circadian timekeeping during early Arabidopsis development. Plant Physiol 147(3):1110-25.

Salter MG, Franklin KA, Whitelam GC. 2003. Gating of the rapid shade-avoidance response by the circadian clock in plants. Nature 426(6967):680-3.

Sanchez A, Shin J, Davis SJ. 2011. Abiotic stress and the plant circadian clock. Plant Signal Behav 6(2):223-31.

Sawa M, Nusinow DA, Kay SA, Imaizumi T. 2007. FKF1 and GIGANTEA complex formation is required for day-length measurement in Arabidopsis. Science 318(5848):261-5.

Schaffer R, Ramsay N, Samach A, Corden S, Putterill J, Carré IA, Coupland G. 1998. The late elongated hypocotyl mutation of Arabidopsis disrupts circadian rhythms and the photoperiodic control of flowering. Cell 93(7):1219-29.

Schultz TF, Kiyosue T, Yanovsky M, Wada M, Kay SA. 2001. A role for LKP2 in the circadian clock of Arabidopsis. Plant Cell 13(12):2659-70.

Searle I, Coupland G. 2004. Induction of flowering by seasonal changes in photoperiod. EMBO J 23(6):1217-22.

Settleman J. 2005. Intercalating Arabidopsis leaf cells: a jigsaw puzzle of lobes, necks, ROPs, and RICs. Cell 120(5):570-2.

Shi H, Ishitani M, Kim C, Zhu JK. 2000. The Arabidopsis thaliana salt tolerance gene SOS1 encodes a putative $\mathrm{Na}+\mathrm{H}+$ antiporter. Proc Natl Acad Sci U S A 97(12):6896-901.

Shin DH, Cho MH, Kim TL, Yoo J, Kim JI, Han YJ, Song PS, Jeon JS, Bhoo SH, Hahn TR. 2010. A small GTPase activator protein interacts with cytoplasmic phytochromes in regulating root development. J Biol Chem 285(42):32151-9. 
Somers DE, Devlin PF, Kay SA. 1998a. Phytochromes and cryptochromes in the entrainment of the Arabidopsis circadian clock. Science 282(5393):1488-90.

Somers DE, Webb AA, Pearson M, Kay SA. 1998b. The short-period mutant, toc1-1, alters circadian clock regulation of multiple outputs throughout development in Arabidopsis thaliana. Development 125(3):485-94.

Somers DE, Schultz TF, Milnamow M, Kay SA. 2000. ZEITLUPE encodes a novel clockassociated PAS protein from Arabidopsis. Cell 101(3):319-29.

Staiger D, Allenbach L, Salathia N, Fiechter V, Davis SJ, Millar AJ, Chory J, Fankhauser C. 2003. The Arabidopsis SRR1 gene mediates phyB signaling and is required for normal circadian clock function. Genes Dev 17(2):256-68.

Strasser B, Sánchez-Lamas M, Yanovsky MJ, Casal JJ, Cerdán PD. 2010. Arabidopsis thaliana life without phytochromes. Proc Natl Acad Sci U S A 107(10):4776-81.

Suárez-López P, Wheatley K, Robson F, Onouchi H, Valverde F, Coupland G. 2001. CONSTANS mediates between the circadian clock and the control of flowering in Arabidopsis. Nature 410(6832):1116-20.

Takai Y, Kaibuchi K, Kikuchi A, Kawata M. 1992. Small GTP-binding proteins. Int Rev Cytol 133:187-230.

Thain SC, Vandenbussche F, Laarhoven LJ, Dowson-Day MJ, Wang ZY, Tobin EM, Harren FJ, Millar AJ, Van Der Straeten D. 2004. Circadian rhythms of ethylene emission in Arabidopsis. Plant Physiol 136(3):3751-61.

Tseng TS, Salomé PA, McClung CR, Olszewski NE. 2004. SPINDLY and GIGANTEA interact and act in Arabidopsis thaliana pathways involved in light responses, flowering, and rhythms in cotyledon movements. Plant Cell 16(6):1550-63.

Valverde F, Mouradov A, Soppe W, Ravenscroft D, Samach A, Coupland G. 2004. Photoreceptor regulation of CONSTANS protein in photoperiodic flowering. Science 303(5660):1003-6.

Verkest A, Weinl C, Inzé D, De Veylder L, Schnittger A. 2005. Switching the cell cycle. Kip-related proteins in plant cell cycle control. Plant Physiol 139(3):1099-106.

Vernoud V, Horton AC, Yang Z, Nielsen E. 2003. Analysis of the small GTPase gene superfamily of Arabidopsis. Plant Physiol 131(3):1191-208.

Vetter IR, Wittinghofer A. 2001. The guanine nucleotide-binding switch in three dimensions. Science 294(5545):1299-304.

Wang ZY, Tobin EM. 1998. Constitutive expression of the CIRCADIAN CLOCK ASSOCIATED 1 (CCA1) gene disrupts circadian rhythms and suppresses its own expression. Cell 93(7):1207-17.

Wang G, Kong H, Sun Y, Zhang X, Zhang W, Altman N, DePamphilis CW, Ma H. 2004. Genome-wide analysis of the cyclin family in Arabidopsis and comparative phylogenetic analysis of plant cyclin-like proteins. Plant Physiol 135(2):1084-99.

Wang J, Tian L, Lee HS, Wei NE, Jiang H, Watson B, Madlung A, Osborn TC, Doerge RW, Chen ZJ. 2006. Genomewide nonadditive gene regulation in Arabidopsis allotetraploids. Genetics 172(1):507-17.

Wenkel S, Turck F, Singer K, Gissot L, Le Gourrierec J, Samach A, Coupland G. 2006. CONSTANS and the CCAAT box binding complex share a functionally important domain and interact to regulate flowering of Arabidopsis. Plant Cell 18(11):2971-84.

Wennerberg K, Rossman KL, Der CJ. 2005. The Ras superfamily at a glance. J Cell Sci 118(Pt 5):843-6.

Wildermuth MC. 2010. Modulation of host nuclear ploidy: a common plant biotroph mechanism. Curr Opin Plant Biol 13(4):449-58.

Wong HL, Pinontoan R, Hayashi K, Tabata R, Yaeno T, Hasegawa K, Kojima C, Yoshioka H, Iba K, Kawasaki T, Shimamoto K. 2007. Regulation of rice NADPH oxidase by binding of Rac GTPase to its N-terminal extension. Plant Cell 19(12):4022-34. 
Xiong L, Schumaker KS, Zhu JK. 2002. Cell signaling during cold, drought, and salt stress. Plant Cell 14 Suppl:S165-83.

Yakir E, Hilman D, Harir Y, Green RM. 2007. Regulation of output from the plant circadian clock. FEBS J 274(2):335-45.

Yamaguchi-Shinozaki K, Shinozaki K. 1993. Characterization of the expression of a desiccation-responsive rd29 gene of Arabidopsis thaliana and analysis of its promoter in transgenic plants. Mol Gen Genet 236(2-3):331-40.

Yamaguchi-Shinozaki K, Shinozaki K. 1994. A novel cis-acting element in an Arabidopsis gene is involved in responsiveness to drought, low-temperature, or high-salt stress. Plant Cell 6(2):251-64.

Yanhui C, Xiaoyuan Y, Kun H, Meihua L, Jigang L, Zhaofeng G, Zhiqiang L, Yunfei Z, Xiaoxiao W, Xiaoming Q, Yunping S, Li Z, Xiaohui D, Jingchu L, Xing-Wang, Zhangliang C, Hongya G, Li-Jia Q. 2006. The MYB transcription factor superfamily of Arabidopsis: expression analysis and phylogenetic comparison with the rice MYB family. Plant Mol Biol 60(1):107-24.

Yanovsky MJ, Mazzella MA, Casal JJ. 2000a. A quadruple photoreceptor mutant still keeps track of time. Curr Biol 10(16):1013-5.

Yanovsky MJ, Whitelam GC, Casal JJ. 2000b. fhy3-1 retains inductive responses of phytochrome A. Plant Physiol 123(1):235-42.

Yu JW, Rubio V, Lee NY, Bai S, Lee SY, Kim SS, Liu L, Zhang Y, Irigoyen ML, Sullivan, Zhang Y, Lee I, Xie Q, Paek NC, Deng XW. 2008. COP1 and ELF3 control circadian function and photoperiodic flowering by regulating GI stability. Mol Cell 32(5):61730.

Yu X, Klejnot J, Zhao X, Shalitin D, Maymon M, Yang H, Lee J, Liu X, Lopez J, Lin C. 2007. Arabidopsis cryptochrome 2 completes its posttranslational life cycle in the nucleus. Plant Cell 19(10):3146-56.

Zeilinger MN, Farré EM, Taylor SR, Kay SA, Doyle FJ. 2006. A novel computational model of the circadian clock in Arabidopsis that incorporates PRR7 and PRR9. Mol Syst Biol 2:58.

Zhang X, Chen Y, Wang ZY, Chen Z, Gu H, Qu LJ. 2007. Constitutive expression of CIR1 (RVE2) affects several circadian-regulated processes and seed germination in Arabidopsis. Plant J 51(3):512-25.

Zhu JK. 2002. Salt and drought stress signal transduction in plants. Annu Rev Plant Biol 53:247-73. 


\section{ÖSSZEFOGLALÁS}

Munkánk során egy kis GTP-kötő fehérjét, a LIGHT INSENSITIVE PERIOD 1-et (LIP1) vizsgáltuk. A LIP1 szerepet játszik a cirkadián óra és a fotomorfogenikus folyamatok szabályozásában, az endoreduplikáció befolyásolásában és bizonyos stressz folyamatokban is. A LIP1 negatív szerepet tölt be a cirkadián óra periódusának szabályozásában és fényintenzitás függő módon képes szabályozni azt. A mutánsban a kék és vörös fényre adott fotomorfogenikus válaszok is megváltoznak. A LIP1 szerepet játszik a vörös és kék fény általi hipokotil megnyúlás gátlásában, azonban a távoli-vörös fény által szabályozott folyamatban nincs szerepe. A lipl mutáns növények szik alatti szára rövidebb, mint a vad típusé olyan nagy intenzitású vörös és kék fényben is, ahol a cirkadián fenotípus már nem figyelhető meg. A LIP1 nagyfokú hasonlóságot mutat a kis GTP-kötő fehérjékkel (Vernoud és mtsai, 2003). A LIP1 fehérjében több olyan motívum is található, ami a klasszikus kis GTP-kötő fehérjékre nem jellemző és több konzervált aminosavban is eltéréseket mutat. A LIP1 a növényi kis GTP-ázok egy új és még nem teljesen jellemzett alcsaládjába tartozik. Jelenleg az egyetlen kis GTP-kötő fehérje, ami funkcionálisan kapcsolatba hozható a cirkadián óra szabályozásával. A cirkadián óra részletes tanulmányozása során egyre több órakomponensről és óra kapcsolt elemről derül ki, hogy pleiotróp funkciókkal rendelkeznek, és fontos szerepük van a sejtek legkülönbözőbb folyamatainak szabályozásában.

A lip1 mutáns növényekben csíranövény stádiumban fényfüggő módon megváltozik a bőrszöveti sejtek alakja és mérete. A fényen nevelt lip1-1 és lip1-2 mutáns csíranövények bőrszöveti sejtjeinek alakja jellegzetes módon eltér a vad típusétól, nem alakul ki a vad típusra jellemző, karéjos sejtalak. Etiolált növények esetében különbség nem figyelhető meg. A lip1 mutáns csíranövények sziklevelében a kromatintartalom megnő fehér, vörös és kék fényben, sötétben azonban nem. Ez arra utal, hogy az endoreduplikáció fény által szabályozott formája szenved zavart a lipl mutánsban. Kifejlett lipl mutáns növényben a sejtalak és a ploidia fenotípus sem figyelhető meg. Hipokotil és teljes növény tartalmú mintákat is vizsgáltunk az örökítőanyag mennyiségét tekintve. A ploidia mintázat ezekben a mintákban nagyon hasonlított a sziklevél esetében tapasztaltra, ami arra utal, hogy a LIP1 által okozott endoreduplikációs változás nem szövet specifikus.

lipl és fotoreceptor többszörös mutánsokat hoztunk létre és mértük a DNS tartalmat a csíranövényekben. A vörös és kék fény által szabályozott ploidia mintázat genetikai analízise a fitokróm B és a kriptokróm 1-2 episztatikus hatását mutatta ki a LIP1 felett. Ezek szerint a LIP1 a fitokróm B és a kriptokróm 1-2 által szabályozott útvonalakon keresztül vesz részt az endoreduplikáció vörös és kék fény-általi gátlásában. 
A lip 1-1 mutáns növényekben a hipokotil hossza vörös és kék fényben megváltozik, a távoli vörös fény függő jelátviteli út azonban érintetlen. A lipl és fotoreceptor kétszeres mutánsokat vizsgálva kimutattuk, hogy a lipl mutáns vörös fényben tapasztalható fotomorfogenikus fenotípusa részben a fitokróm B-től, valamint kék fényben a kriptokróm fotoreceptoroktól függ.

A magasabb ploidia szinttel rendelkező sejtek általában nagyobbak vagy megnyúltak a normál kromatin mennyiséggel rendelkező sejtekhez képest. Ezért az endoreduplikációnak feltehetőleg szerepe van a szik alatti szár megnyúlásában. A lipl mutánsok szik alatti szára rövidebb, mint a vad típusé folyamatos vörös, illetve kék fényben. Ez arra utal, hogy a fotomorfogenikus fenotípust nem az endoreduplikáció gátlásának megszünése okozza. Mindkét fenotípus megfigyelhető vörös és kék fényben, de távoli vörösben nem, valamint mindkét fenotípus függ a fitokróm B-től és a kriptokróm 1-2-től egyaránt. Ebből arra következtethetünk, hogy a LIP1 a fitokróm B és kriptokróm 1-2 által szabályozott jelátviteli útvonal egy olyan közös pontján helyezkedik el, ahol még a hipokotil megnyúlásáért és az endoreduplikációért felelős útvonalak nem váltak szét.

A lip1 mutáns növények rosszabbul fejlődnek magas $\mathrm{NaCl}$ tartalmú táptalajon, mint a vad típusú növények. A csírázási képesség és a gyökér növekedése is zavart szenved. A csírázási képességet vizsgáltuk fény/sötét cikluson és folyamatos sötétben nevelt növényekben is. A lip1-2 mutánsok mindkét esetben érzékenyebbek voltak a vad típusnál a tápközeg magas sókoncentrációjára, utalva ezzel arra, hogy a sóérzékenység nem egy fényfüggő zavar következménye (mint például a ploidia szint változásáé).

Az ozomotikus stressz korai stresszválasz gének indukciójához vezet, ilyenek az $R D 29 A$ (RESPONSIVE TO DESICCATION 29A), RD29B és a RAB18 (RESPONSIVE TO ABA 18). $\mathrm{Az}$ ionikus stressz (emelkedett $\mathrm{Na}^{+}$koncentráció a sejten belül) pedig az SOS2 (SALT OVERLY SENSITIVE 2) indukcióját idézi elő, ami egy $\mathrm{Na}^{+} / \mathrm{H}^{+}$antiporter, az SOS1 aktivátora (Batelli és mtsai, 2007). A lipl mutánsban ozmotikus stressz hatására az ABA függő és független gének indukciós kinetikája vad típuséhoz hasonló, ez alapján feltételezhető, hogy a LIP1 hiányában nem a stressz érzékelése, a szignalizációs kaszkád vagy a jelátviteli utak transzkripciójának aktiválása sérül. A lip1 mutáns növények fokozott érzékenységet mutatnak további ionikus $\left(\mathrm{Cs}^{2+}, \mathrm{K}^{+}, \mathrm{Li}^{2+}\right)$ és ozmotikus stresszre, valamint a hőmérséklet stresszre is.

A sóérzékeny fenotípus nem hozható kapcsolatba az endoreduplikációban bekövetkező változásokkal, mivel a mutáns növények olyan körülmények között is érzékenyek sóra (folyamatos sötétben), ahol a ploidia fenotípus nem érvényesül. A só stressz nem befolyásolta a cirkadián óra LIP1 hiányában tapasztalható megváltozott müködését sem. 
A cirkadián óra nem megfelelő müködése,vagyis a periódus rövidülése sötétben nevelt lip1 mutáns növényekben is megfigyelhető (Kevei és mtsai, 2007). Ilyen körülmények között a ploidia szint nem különbözik lipl és vad típusú növényekben. Továbbá, a sóérzékenység, a fotomorfogenikus fenotípus és a ploidia számbeli változás olyan körülmények között is megfigyelhető, ahol a mutánsnak nincs cirkadián fenotípusa (például erős fehér fényben) (Kevei és mtsai, 2007). Ezek a tények arra utalnak, hogy a lipl mutánsokban a cirkadián óra megváltozott müködése nem a stressz, a ploidia vagy a fotomorfogenikus fenotípus következménye.

A LIP1 fehérje a citoplazmában és a sejmagban egyaránt jelen van. Felmerült a kérdés, hogy a fent említett pleiotróp fenotípusok köthetőek-e a fehérje sejten belüli elhelyezkedéshez, ezért olyan növényeket állítottunk elő, amelyek a lip1-2 mutáns háttérben YFP-LIP1 fúziós fehérjét fejeznek ki nukleáris lokalizációs szignállal (NLS) illetve nukleáris export szignállal (NES) ellátva. A cirkadián fenotípus helyreállítható LIP1-YFP és LIP1-YFP-NLS fúziós fehérjékkel, azonban LIP1-YFP-NES fúziós fehérjével nem, ami arra utal, hogy a cirkadián funkció betöltéséhez a LIP1 fehérjének a sejtmagban egy kritikus mennyiség felett kell jelen lennie. A többi fenotípus (sejtalak, ploidia, hipokotil, stressz) egyaránt komplementálható volt mindhárom fúziós fehérjével. Ezekben az esetekben nem jelenthető ki egyértelműen, hogy mely sejtalkotóhoz köthető a funkció.

A LIP1 fontos szerepet tölt be kedvezötlen körülmények között a csírázás szabályozásában, alacsony fényintenzitás mellett a cirkadián óra beállításában, valamint a fiatal csíranövények morfológiájának kialakításában. Mindezek alapján a LIP1 a csíranövények fejlődésének fontos regulátora. Azonban kizárt, hogy a LIP1 összes funkciója a csíranövény állapotra korlátozódna, mivel kifejeződése a legtöbb szervben kimutatható idősebb növényben is. Kifejlett lip1 mutáns növényben a sejtalak és a ploidia fenotípus nem figyelhető meg, ami vagy a fejlődés során eltérő módon szabályozott és funkcionálisan a LIP1-gyel redundáns fehérjék jelenlétével magyarázható, vagy pedig a fejlődés különböző stádiumaiban jelenlevő eltérő kölcsönható partnerekkel. Azoknak a LIP1-gyel konformáció-függő módon kölcsönható fehérjéknek az azonosítása, melyek a LIP1 aktivitását szabályozzák, vagy éppen a LIP1 által szabályozódnak, kulcsfontosságú lehet a LIP1 különböző szignalizációs utakban betöltött szerepének a megismeréséhez.

RNS szinten a CCA1 és TOC1 esetében a maximális kifejeződésében csökkenést tapasztaltunk fény/sötét cikluson nevelt növényekben. A kifejeződés mintázata nem változott számottevően a GI és a PRR9 gének esetében a mutánsban a vad típushoz képest. A lip1 mutáció a fenntiek alapján negatív hatással lehet a TOC1 transzkripciójára, ami viszont a 
CCA1 transzkripciót serkentené, ez magyarázza, hogy a lip1-2 mutánsban mindkettő csökkent kifejeződést mutat.

Az óragének mutációját (CCA1, GI, TOC1, PRR9, PRR5) a lip1 mutációval kombinálva sikerült kimutatnunk, hogy a LIP1 és a cirkadián óra között az összekötő elem a GI órakomponens. A GI episztatikus hatása nemcsak a cirkadián fenotípus esetében érvényesül, megfigyelhető a sóérzékeny és a fotomorfogenikus fenotípusok esetében is.

A GI-ról nemrégiben mutatták ki, hogy szerepet játszik a sóstressz-tolerancia kialakításában (Kim és mtsai, 2013). A vizsgált gi-1 allélt hordozó mutáns toleránsnak bizonyult sóval szemben. A GI képes komplexet képezni az SOS2-vel, ami az SOS útvonal egyik komponense, és nélkülözhetetlen a citoplazma megfelelő ion-koncentrációinak fenntartásához és a sóstressz tolerálásához (Zhu, 2002). A komplex gátolja az SOS2 aktivitását stresszmentes körülmények között, azonban sóstressz hatására az SOS2 felszabadul és aktiválja az SOS1 $\mathrm{Na}^{+} / \mathrm{H}^{+}$antiportert (Kim és mtsai, 2013). Eredményeik alapján érdemes lenne megvizsgálni, hogy fehérje szinten a LIP1-nek van-e hatása az SOS rendszer komponenseire, esetleg befolyásolja-e a GI-SOS2 komplex kialakulását. Mi az SOS2-t transzkripciós szinten vizsgáltuk lip1 mutánsban és nem tapasztaltunk változást LIP1 hiányában.

A LIP1 nem transzkripció szintjén van hatással a GI-re. A GI pozitívan szabályozza a TOC1 transzkripcióját, ami szintén pozitív hatással van a CCA1 transzkripcióra. Ezért feltételezhetö, hogy a lipl mutánsban tapasztalt CCA1 és TOC1 mRNS szint csökkenés a LIP1 és GI kölcsönhatásának következménye. A ccal és a tocl mutánsok egyaránt rövid periódust mutatnak (Alabadí és mtsai, 2002; Somers és mtsai, 1998). Ezek alapján a lip1 mutánsban tapasztalt rövid periódus lehetséges, hogy a csökkent CCA1 és TOC1 szint következménye, bár ennek ellentmond a CCA1 és LIP1 vagy TOC1 és LIP1 gének közti episztatikus kölcsönhatás hiánya. 


\section{SUMMARY}

\section{Introduction}

The optimal growth and development of plants are mediated by various signaling pathways that enable plants to modulate their molecular and physiological reactions in response to changes of the environment. To monitor changes in ambient light conditions, plants evolved several families of photoreceptors. The red/far-red light-absorbing phytochromes (PhyA-PhyE) and the blue light-absorbing cryptochromes (CRY1 and CRY2) are considered to mediate the majority of physiological and developmental responses to visible light. These photoreceptors also play an essential role in entraining/synchronizing the circadian clock to the daily light/dark cycles (Devlin and Kay, 2000). Circadian clocks are biochemical timers regulating many physiological and molecular processes according to the day/night cycle. The central clockwork generates the primary oscillation in the expression of clock components with a period of about $24 \mathrm{~h}$.

The rhythm generating module of the Arabidopsis thaliana clock consists of at least three interconnected feedback loops (McWatters and Devlin, 2011). The "central loop" functions through the reciprocal regulation between the CCA1, LHY and TOC1 genes (Alabadí et al., 2001). The morning-expressed CCA1/LHY Myb transcription factors repress the TOC1 gene; conversely, the evening-expressed TOC1 positively regulates the transcription of CCA1/LHY. The "evening loop" is formed by TOC1 and a hypothetical factor Y, both expressed in the evening. Y positively regulates $T O C 1$, whereas TOC1 represses $Y$ transcription, which is also inhibited by CCA1/LHY. TOC1 promotes CCA1/LHY transcription via another hypothetical component; X. GI (a nuclear protein with unknown biochemical function) is an essential contributor to Y function (Locke et al., 2005; Zeilinger et al., 2006). The "morning loop" is formed by CCA/LHY and PRR7/9 (Makino et al., 2000). CCA1/LHY activates PRR7/9 expression in the morning; conversely, PRR7/9 inhibit CCA1/LHY during the rest of the day.

Circadian regulation is clearly overrepresented among the genes that are implicated in light, hormonal, or stress signaling, suggesting a molecular basis for the temporal modulation of these pathways (Covington et al., 2008). Adaptation to the changing environment also requires plasticity of the developmental program both at the organism and cell levels.

Previously, we identified the small GTPase LIGHT INSENSITIVE PERIOD1 (LIP1) as a circadian clock associated factor in Arabidopsis (Kevei et al., 2007). Loss of LIP1 function in the lip 1-1 mutant severely reduced the effect of light on the shortening of freerunning period. 


\section{Results}

\section{Loss of function of LIP1 protein causes altered cell shape}

Microscopic analysis of young lip1-1 and lip1-2 mutant seedlings (Kevei et al., 2007) revealed defects in cell development. In wild-type Arabidopsis plants, pavement cells have a characteristic jigsaw puzzle shape with lobes, whereas in lip1-1 and lip1-2 mutants the cell shape is more rounded and much less complex. Pavement cells in the first true leaves of lip1-1 and lip1-2 mutants had wild-type morphology.

\section{LIP1 affects ploidy levels at the seedling stage}

The alteration of cell morphology is frequently linked with changes in nuclear DNA content (Guimil and Dunand, 2007). Therefore, we analyzed ploidy patterns in the cotyledons of lipl mutants by flow cytometry and found that the proportion of nuclei having high DNA content was increased in the mutants. Ploidy patterns in isolated hypocotyls of the lip 1-2 mutant showed the same tendency as in the cotyledons, demonstrating that in the seedling stage the effect of LIP1 on endoreplication is not organ specific. Ploidy patterns in the matured first leaves of lipl-2 and wild-type plants were not significantly different suggesting that LIP1 suppresses ploidy levels in a developmentally regulated manner.

\section{Light-dependent inhibition of endoreplication by LIP1}

Four cycles of endoreplication could occur in dark grown Arabidopsis seedlings, whereas the fourth cycle is inhibited in light (Gendreau et al., 1998). We analyzed ploidy patterns in lip1 mutants grown under different light conditions. Elevated ploidy level was detected in lip1 seedlings grown under light/dark cycles and the DNA content increased further when plants were grown in continuous white light. Ploidy levels were identical in etiolated lipl and wildtype seedlings. In red light, the light-induced inhibition of endoreplication depends on the photoreceptor PhyB (Gendreau et al., 1998). We tested the epistatic relation between LIP1 and PhyB in controlling red light-dependent endoreplication. In continuous red light (cR), both lip1-2 and phyB-9 mutants showed similarly increased ratios of $16 \mathrm{C}$ and $32 \mathrm{C}$ nuclei. The lip12 phyB-9 double mutant phenocopied the phyB-9 single mutant in $\mathrm{cR}$. The DNA content of these mutants grown in darkness displayed patterns like in wild-type seedlings. Ploidy level of lip 1-2 mutant showed significant increases in cB, but it was indistinguishable from the wild type in cFR. The mutation in the LIPl gene was combined with the cryl cry2 and PhyA211mutations. In $\mathrm{cB}$, the ploidy pattern of the lip1-2 cryl cry2 triple mutant was most similar to that of the cryl cry2 double mutant. In cFR, the lip1-2 phyA-211 double mutant phenocopied the phyA-211 single mutant. 


\section{The function of LIP1 in controlling photomorphogenesis depends on PhyB, CRY1, and CRY2 but is independent of PhyA}

It had been demonstrated that lip 1-1 mutants show elevated photomorphogenic responses to red and blue light but not to far-red light (Kevei et al., 2007). We characterized the responsiveness of lip1-2 phyB-9, lip1-2 phyA-211, and lip1-2 cryl cry2 multiple mutants to red, far-red, and blue light, respectively. In $\mathrm{cR}$, the lip1-2 mutant showed significantly shorter hypocotyls than the wild type; however, the lip1-2 phyB-9 double mutant produced hypocotyls much longer than the wild type and was very similar to that of the phyB-9 single mutant. In $\mathrm{cB}$, the lip1-2 mutant displayed significant hypersensitivity compared with the wild-type, but lip1-2 cryl cry2 produced long hypocotyls similar to the cryl cry2 double mutant. In cFR, lip1-2 phenocopied wild-type plants, and the lip1-2 phyA-211 double mutant showed hypocotyl lengths identical to those of the phyA-211 mutant.

\section{lip1 mutants are hypersensitive to stress}

lip1 mutants grown under 12-h-light/12-h-dark cycles displayed an increased sensitivity to salt $(\mathrm{NaCl})$. In addition to poor growth and development, the germination rate of lipl-2 seedlings was also significantly reduced and the relative inhibition of root growth was significantly stronger in the lipl mutants under salt stress conditions as compared to the wild type. We have also analyzed germination rate in dark-grown plants. lip 1-2 mutants were more sensitive than wild-type plants, indicating that the salt stress phenotype is not caused by other light-dependent defects of lip. We tested the effect of salt stress on the clock function in lip1 mutants. There was no observable connection between the hypersensitivity to salt and the defect of the clock function.

Osmotic stress leads to the induction of early stress inducible genes like RESPONSIVE TO DESICCATION29 A (RD29A), RD29B, or RESPONSIVE TO ABA 18 (RAB18), whereas ionic stress induces the transcription of SOS2 (SALT OVERLY SENSITIVE2), an activator of the $\mathrm{Na}^{+} / \mathrm{H}^{+}$transporter SOS1. Salt-induced expression of RD29A, RD29B, RAB18, and SOS2 genes was monitored by quantitative reverse transcription (qRT)-PCR. There were no significant differences in the kinetics or the level of induction of these genes in the mutant. These results indicate that LIP1 plays a minor role, if any, in sensing salt stress signals and the transcriptional activation of the salt stress related genes tested.

The lipl mutants grown under 12-h-light/12-h-dark cycles displayed an increased sensitivity to $\mathrm{K}^{+}, \mathrm{Cs}^{2+}, \mathrm{Li}^{2+}$ and heat stress as well. These data indicate that LIP1 has a more general role in the regulation of responses to abiotic stress conditions. 


\section{Subcellular localization of LIP1}

We showed previously that the yellow fluorescent protein YFP-LIP1 fusion protein is detectable both in the cytosol and in the nucleus and that this distribution pattern is not affected by light conditions or the circadian clock (Kevei et al., 2007). To test if any of the pleiotropic functions of LIP1 require specific subcellular localization, we generated transgenic lip1 plants expressing the LIP1-YFP fusion protein with or without nuclear localization signal (NLS) or nuclear export signal (NES). Transgenic lines with comparable expression levels were selected and localization of the different LIP1 fusion proteins was analyzed by fluorescence microscopy. As expected, YFP-LIP1 was detectable both in the cytoplasm and in the nuclei, whereas YFP-LIP1-NLS and YFP-LIP1-NES were clearly restricted to the nucleus and the cytoplasm.

\section{Nuclear localization of LIP1 is essential for its circadian function}

Complementation of the ploidy, salt stress, photomorphogenic, and circadian phenotypes of the lip1 mutants was tested in the selected transgenic lines. Expression of YFP-LIP1, YFPLIP1-NLS, or YFP-LIP1-NES in the lip1 mutant background restored ploidy levels to the wildtype level. The jigsaw shape of cotyledon pavement cells was also restored in all complemented lines. Furthermore, lip1-2 plants expressing either of the LIP1 fusion proteins were able to tolerate $100 \mathrm{mM} \mathrm{NaCl}$ and develop similarly to wildtype plants. Hypocotyl lengths of either of the complemented lines grown in red, blue, or far-red light were also indistinguishable from that of the wild type. The expression of YFP-LIP1 or YFP-LIP1-NLS restored wild-type circadian rhythms, whereas YFP-LIP1-NES-expressing transgenic lip1-2 seedlings displayed rhythms very similar to that of lip1-2. Period estimates quantitatively demonstrated full complementation or the complete lack of complementation as indicated. We conclude that for the regulation of the circadian clock, a significant portion of LIP1 needs to be present in the nucleus. These observations suggest that the function of LIP1 in the circadian clock can be separated from its role in the control of cell development, endoreplication, stress tolerance, and photomorphogenesis.

\section{Integrating LIP1 into the plant circadian network}

The lack of LIP1 causes short period phenotype with all tested output marker genes (CCR2, CAB, PRR9, CCA1, LHY, GI), proving its importance in the plant circadian network. We measured the mRNA of core clock components in lip1 mutants grown under 12-hlight/12-h-dark cycles and found that the peak level of CCA1 and TOC1 mRNA decreased significantly compared to the wild type. Examination of genetic interactions between LIP1 
and TOC1, CCA1, PRR5, PRR9 and GI genes via double mutant analysis revealed that GI is a clock component mediating LIP1 action. GI has epistatic effect on LIP1, regarding the circadian, photomorphogenic and the stress phenotype as well. The relation between GI and LIP1 is probably responsible for the decrease in the mRNA levels of CCA1 and TOC1, based on the positive transcriptional regulation between GI and TOC1 and between TOC1 and CCA1. ccal and tocl mutants have short period phenotype. The decrease in CCA1 and TOC1 level can contribute to the short period phenotype of the lip1 mutant in part.

\section{Conclusions}

In this work, we provide physiological and molecular data demonstrating the following remarks:

1. LIP1 is required for the normal development of pavement cells in young seedlings.

2. LIP1 is a component of the PhyB-controlled red light and CRY-controlled blue light signaling cascade inhibiting endoreplication and LIP1 is involved in mediating PhyB- and CRY-controlled photomorphogenesis.

3. LIP1 function is required for stress tolerance.

4. By manipulating the subcellular localization of LIP1, we show that the circadian function of LIP1 can be separated from its other functions, not only at the physiological level but also at the cellular level. Nuclear localised LIP1 is required for proper clock function.

5. The cell shape, ploidy, hypocotil and stress phenotype could be complemented with LIP1YFP, LIP1-YFP-NLS and LIP1-YFP-NES fusion constructs as well.

6. The lack of LIP1 causes short period phenotype of all tested output marker genes (CCR2, $C A B, P R R$, CCA1, LHY, GI). At the mRNA level, we could observe decrease in the maximum level of the CCAI and TOC1 expression. Examination of clock gene/lip1 double mutants showed that gi mutation has epistatic effect above lip1 mutation regarding the circadian, hypocotil and stress phenotype as well. 


\section{KÖSZÖNETNYILVÁNÍTÁS}

A dolgozatban szereplő kísérleteket a Magyar Tudományos Akadémia Szegedi Biológiai Központjának Növénybiológiai Intézetében, a Foto- és Kronobiológiai Csoport tagjaként végeztem.

Köszönettel tartozom csoportvezetőmnek, Dr. Nagy Ferencnek és témavezetőmnek, Dr. Kozma-Bognár Lászlónak jelentős anyagi es szellemi támogatásukért. Valamint köszönöm a Foto- és Kronobiológiai Csoport minden tagjának a munkám iránt tanusított érdeklődésüket. Köszönöm Dr. Dudits Dénes volt-, Dr. Ormos Pál jelenlegi föigazgató és Dr. Vass Imre igazgató uraknak, hogy munkámat lehetővé tették.

Köszönöm Dr. Gyula Péternek és Kozma-Bognárné Hajdu Anitának a szakmai segítséget a munkám kezdeti időszakában. Köszönöm Dr. Tóth Rékának az endoreduplikációs vizsgálatokhoz szükséges kísérletek elvégzését.

Köszönöm Jószai Katalin és Veres Gabriella asszisztenseknek a kísérletek előkészítésében nyújtott segítséget.

Köszönöm Dr. Fehér Balázsnak dolgozatom írása során hasznos tanácsait és észrevételeit. 